\title{
National Register Testing of Site 41BT427, Burnet County, Texas
}

Clayton M. Tinsley

Tiffany Osburn

Follow this and additional works at: https://scholarworks.sfasu.edu/ita

Part of the American Material Culture Commons, Archaeological Anthropology Commons, Environmental Studies Commons, Other American Studies Commons, Other Arts and Humanities Commons, Other History of Art, Architecture, and Archaeology Commons, and the United States History Commons

Tell us how this article helped you.

This Article is brought to you for free and open access by the Center for Regional Heritage Research at SFA ScholarWorks. It has been accepted for inclusion in Index of Texas Archaeology: Open Access Gray Literature from the Lone Star State by an authorized editor of SFA ScholarWorks. For more information, please contact cdsscholarworks@sfasu.edu. 


\section{National Register Testing of Site 41BT427, Burnet County, Texas}

\section{Licensing Statement}

This is a work for hire produced for the Texas Department of Transportation (TxDOT), which owns all rights, title, and interest in and to all data and other information developed for this project under its contract with the report producer. The report may be cited and brief passages from this publication may be reproduced without permission provided that credit is given to TXDOT and the firm that produced it. Permission to reprint an entire chapter, section, figures or tables must be obtained in advance from the Supervisor of the Archeological Studies Branch, Environmental Affairs Division, Texas Department of Transportation, 125 East 11th Street, Austin, Texas, 78701. 


\section{NATIONAL REGISTER TESTING OF SITE 41BT427, BURNET COUNTY, TEXAS (CSJ 1198-02-017)}

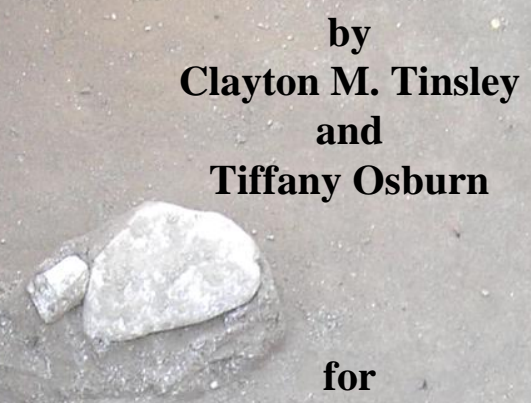

Texas Department of Transportation

Environmental Affairs Division

Austin, Texas

Archeological Studies Program Report Number 127

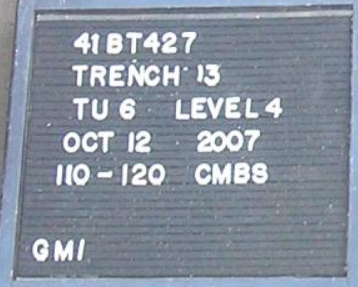

TeXAS ANTIQUities PeRmit NUMBer 4669

MISCELLANEOUS REPORTS OF INVESTIGATIONS

NuMber 501 



\title{
NATIONAL REGISTER TESTING OF SITE 41BT427, BURNET COUNTY, TEXAS (CSJ 1198-02-017)
}

\author{
by \\ Clayton M. Tinsley \\ Tiffany Osburn \\ Principal Investigator \\ Melissa Green \\ for \\ Texas Department of Transportation \\ Environmental Affairs Division \\ 118 East Riverside Drive \\ Austin, Texas 78704 \\ ARCHEOLOGICAL STUDIES PROGRAM REPORT NUMBER 127
}

TEXAs AnTIQUities PeRMit No. 4669

MISCELLANEOUS REPORTS OF INVESTIGATIONS

NUMBER 501

Geo-Marine, Inc.

2201 K Avenue, Suite A2

Plano, Texas 75074

August 2010

ISBN 1-930788-95-9 
Copyright (C) 2010

Texas Department of Transportation (TxDOT)

This is a work for hire produced for the Texas Department of Transportation (TxDOT) which owns all rights, title, and interest in and to all data and other information developed for this project under Contract/Work Authorization \#57902SA005. Brief passages from this publication may be reproduced without permission provided that credit is given to TxDOT and Geo-Marine, Inc. Permission to reprint an entire chapter, section, figures, or tables must be obtained in advance from the Supervisor of the Archeological Studies Program, Environmental Affairs Division, Texas Department of Transportation, 125 East 11th St., Austin, Texas 78701-2483. Copies of this publication have been deposited with the Texas State Library in compliance with the State Depository requirements.

Printed by Sir Speedy, Richardson, Texas

published by:

Texas Department of Transportation

Environmental Affairs Division

Archeological Studies Program

Scott Pletka, Ph.D., Supervisor

Archeological Studies Program Report No. 127

A. McGraw, Series Editor

and

Geo-Marine, Inc.

Plano, Texas

Miscellaneous Reports of Investigations, Number 501

GMI Project No. 22005.00.02

ISBN 1-930788-95-9 


\section{MANAGEMENT SUMMARY}

Between October 1 and October 19, 2007, archeologists from Geo-Marine, Inc., conducted National Register of Historic Places eligibility testing at site 41BT427 in Burnet County, Texas, under contract to the Texas Department of Transportation, Environmental Affairs Division. This prehistoric site was originally recorded by PBS\&J during a cultural resources survey for a proposed bridge replacement project at the North Rocky Creek crossing of FM 963 (CSJ 119802-017). During that investigation, the site was initially identified by a series of three trenches located on the northeastern quadrant of the right-of-way. Three small, burned rock features were originally recorded in two of the trenches.

During the current project by Geo-Marine, the bridge replacement area was again investigated. Thirteen trenches were dug within the project area: nine survey trenches in the northwest, southwest, and southeast quadrants outside the known boundary of site 41BT427, and four trenches within the site itself in the northeast quadrant. The current investigation within site 41BT427 involved the mechanical excavation of the four trenches (29.5 linear meters) and the hand excavation of eight test units (8.94 cubic meters) within the site boundary (an additional test unit was excavated south of the site boundary). Only one definable cultural component was identified at site 41BT427. This site appears to represent an ephemeral, short-term camp with a very sparse material signature. No diagnostic material was recovered during excavation. The single feature identified consisted of a very small, disarticulated cluster of six burned rocks and a limited amount of cultural material. The general lack of cultural material and feature/artifact associations within the site hampers the ability to draw conclusions regarding site function and prehistoric activity.

Due to the low artifact density and the lack of cultural features, site 41BT427 does not have the potential to make significant contributions to the knowledge of the region. Thus, site 41BT427 fails to meet the standards of Criterion D or any other significance standard required for assessing National Register eligibility. Site 41BT427 is recommended not eligible for National Register inclusion, and no further archeological investigations are recommended.

In addition to site testing, survey trenching (as well as an additional test unit) within the remaining three quadrants that was not completed during the initial PBS\&J cultural resources survey was conducted as a part of this Geo-Marine investigation. Based on trench observations 
and background research, this proposed borrow area is highly unlikely to contain archeological historic properties (36 CFR 800.16:[I]) or State Archeological Landmarks (13 TAC 26.12), and no further archeological investigations are recommended for these areas. 


\section{TABLE OF CONTENTS}

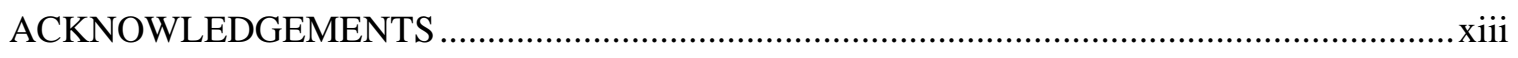

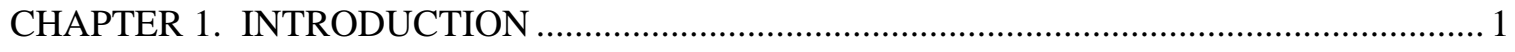

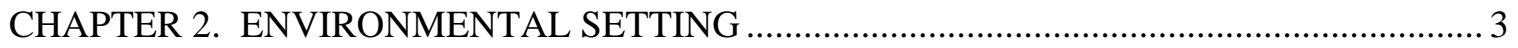

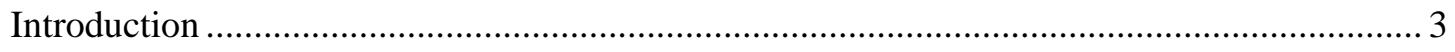

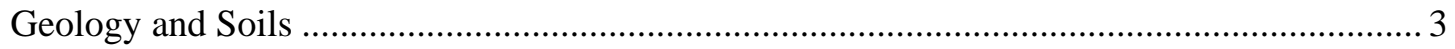

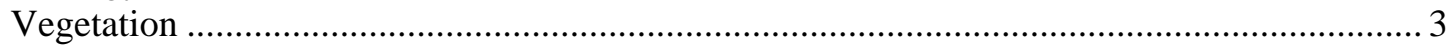

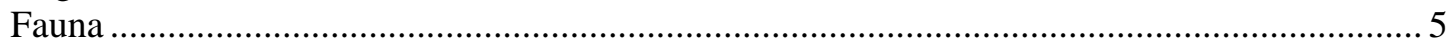

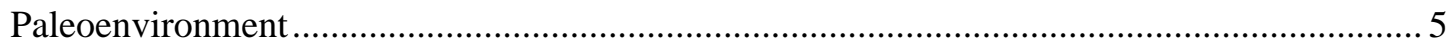

CHAPTER 3. REGIONAL CULTURAL HISTORY AND PREVIOUS INVESTIGATIONS .... 7

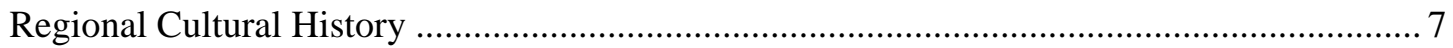

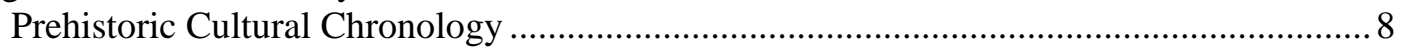

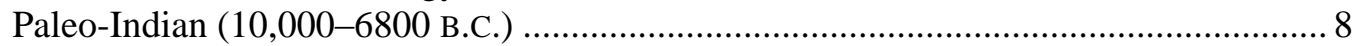

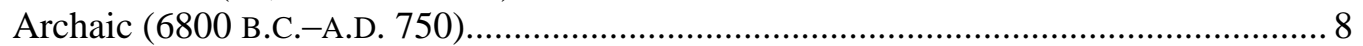

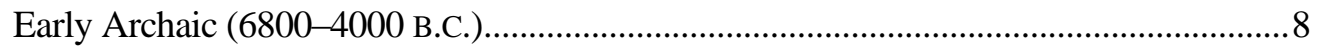

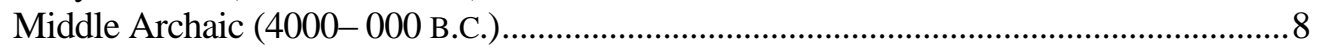

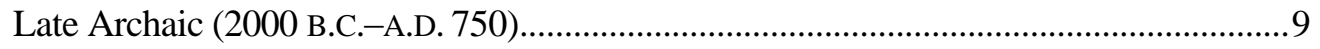

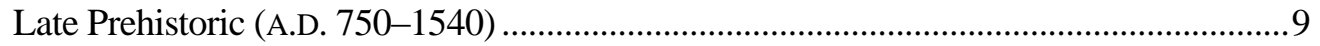

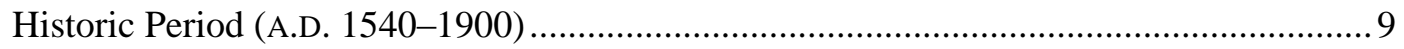

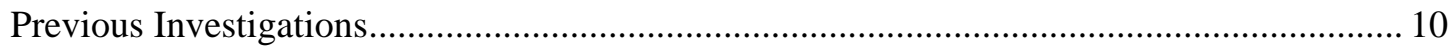

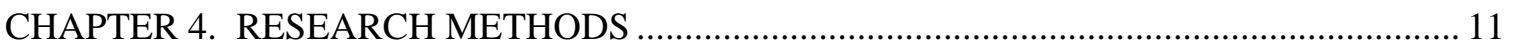

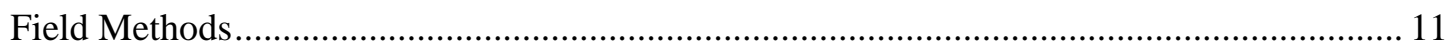

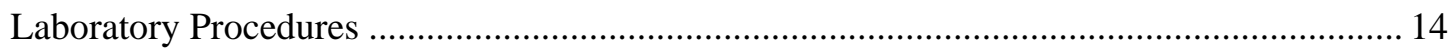

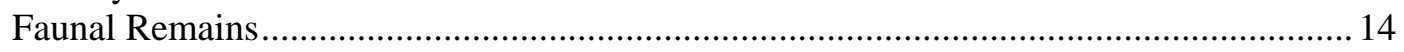

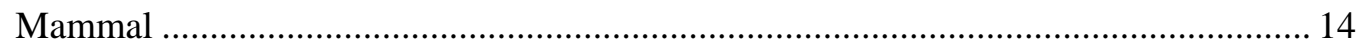

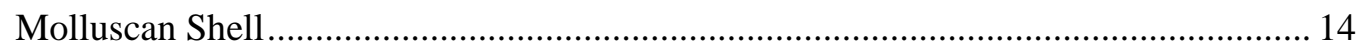

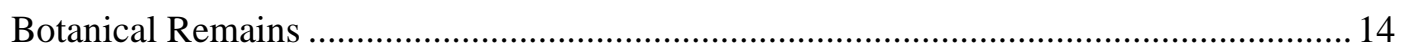

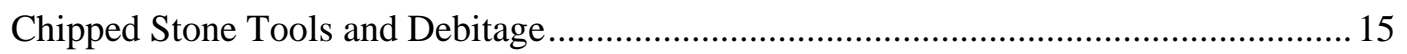

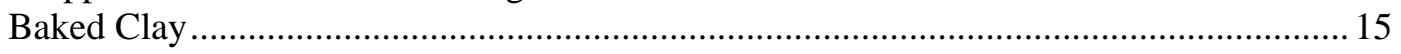

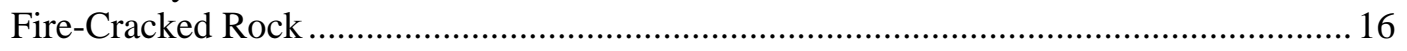

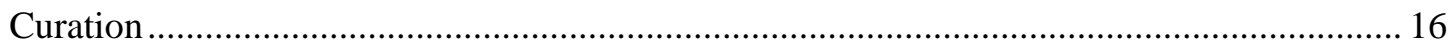




\section{Table of Contents}

(cont'd)

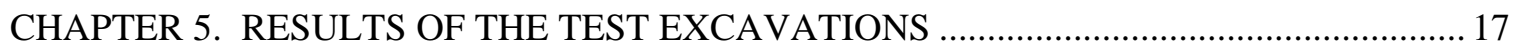

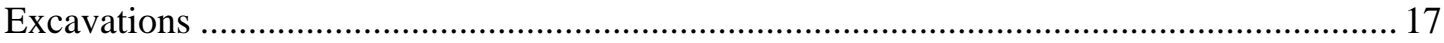

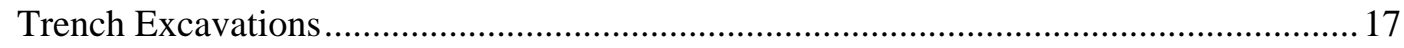

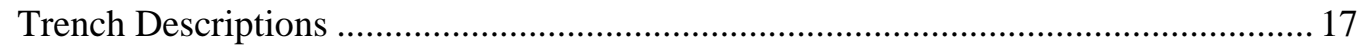

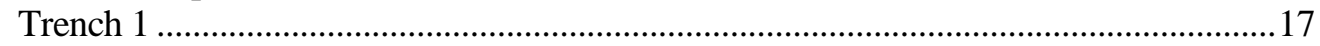

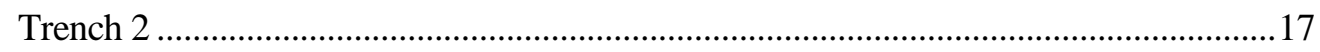

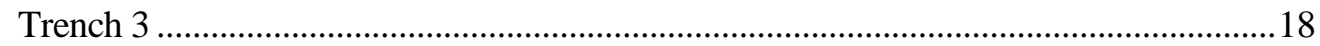

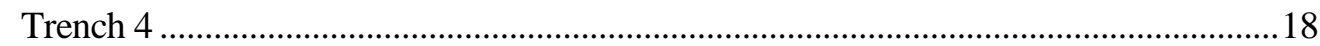

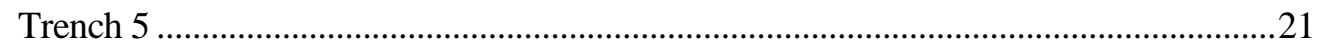

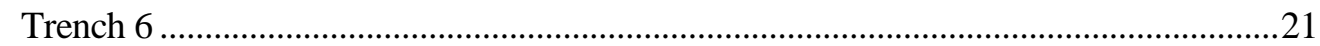

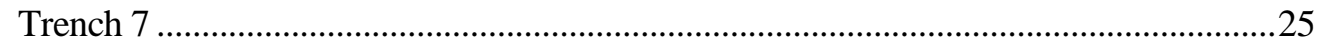

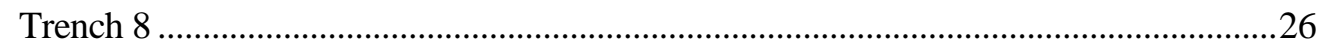

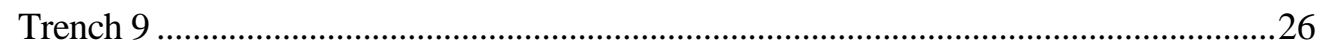

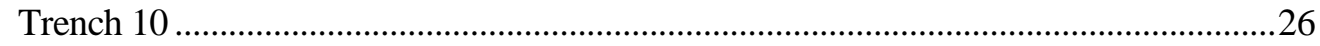

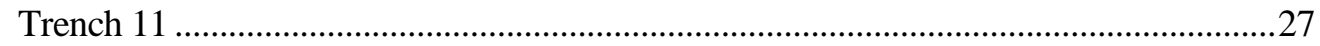

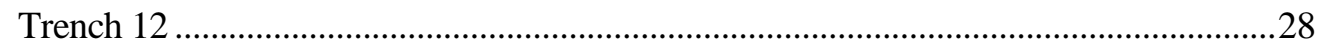

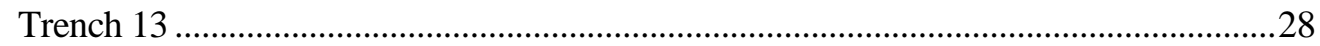

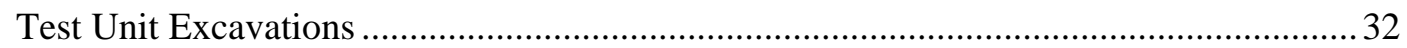

Test Unit 1 (98.83-98.38 m Elevation [174-219 cm bs]) ....................................... 34

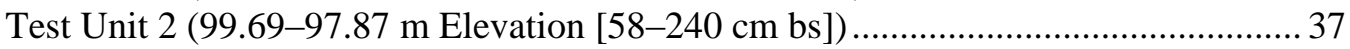

Test Unit 3 (99.55-98.15 m Elevation [55-195 cm bs]) .......................................... 37

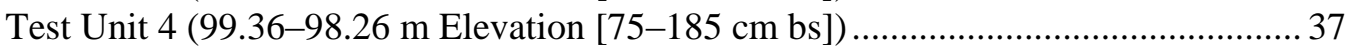

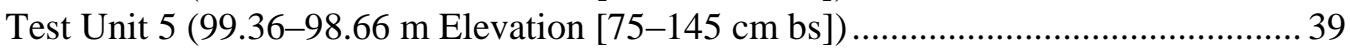

Test Unit 6 (99.49-98.18 m Elevation [76-210 cm bs]) ........................................... 41

Test Unit 7 (99.49-98.58 m Elevation [77-170 cm bs]) ........................................ 41

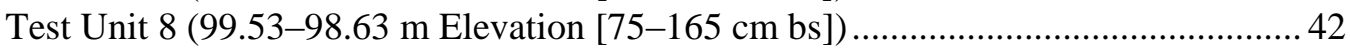

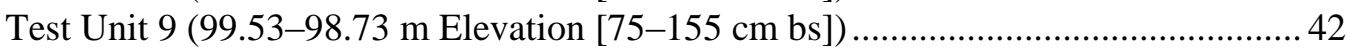

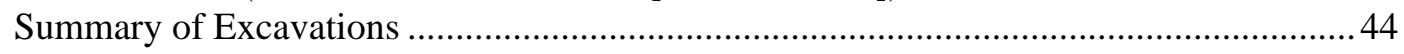

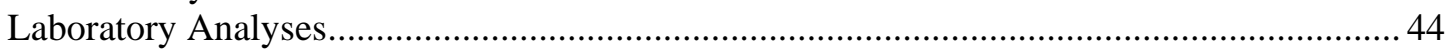

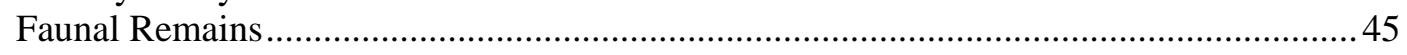

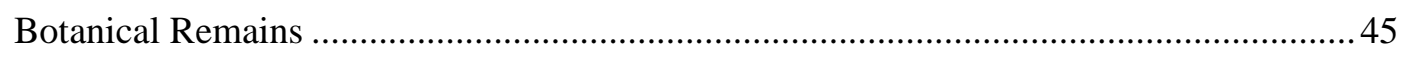

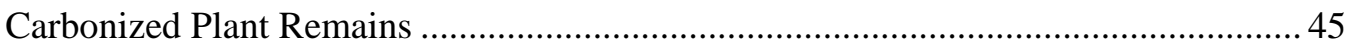

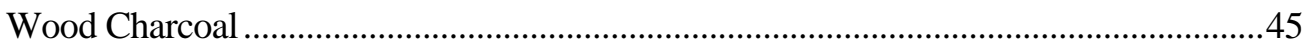

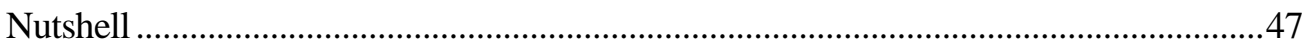

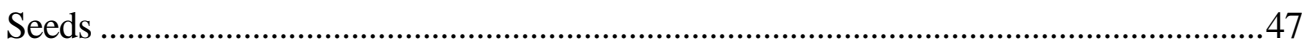

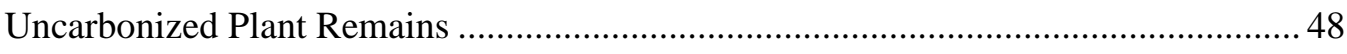

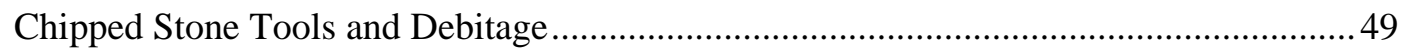

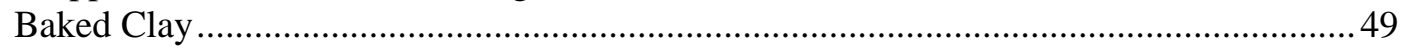

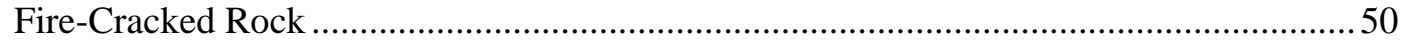


Table of Contents

(cont'd)

CHAPTER 6. SUMMARY AND RECOMMENDATIONS ….............................................. 51

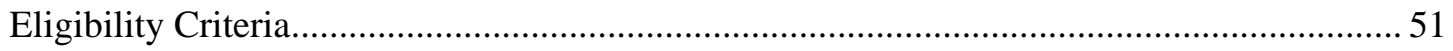

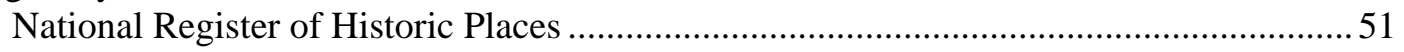

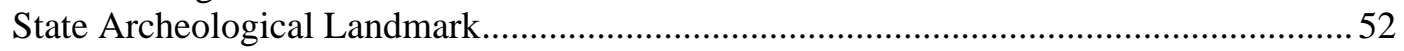

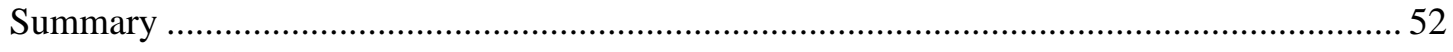

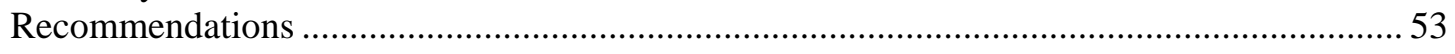

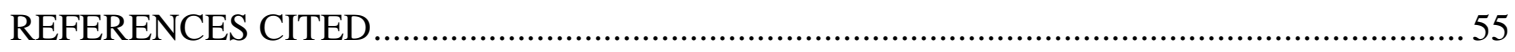

APPENDICES:

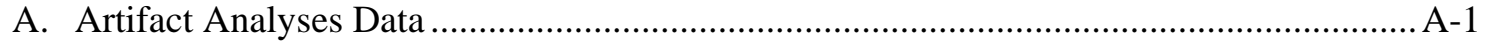

B. Plant Remains from Site 41BT427, Burnet County, Texas ............................................ B-1

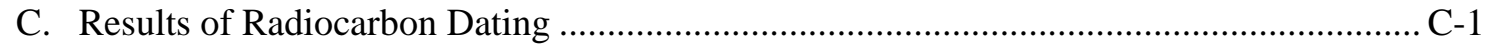





\section{LIST OF FIGURES}

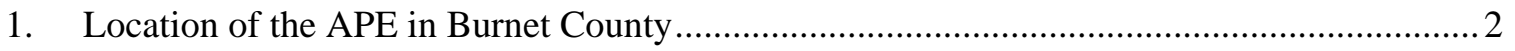

2. Aerial imagery showing soil types in the vicinity of the project area................................... 4

3. Location of trenches within the APE, FM 963 and North Rocky Creek, Burnet County ...... 12

4. Plan map of site 41BT427 showing the location of Test Units 1-9 and Trenches 7-13 ........ 13

5. Trench 1 north wall profile ....................................................................................... 19

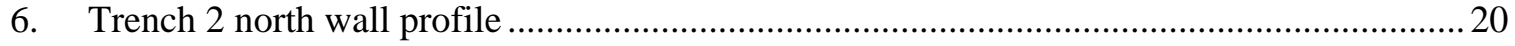

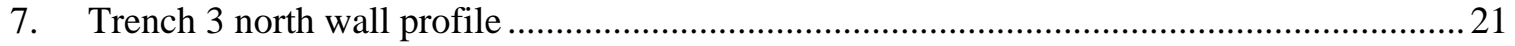

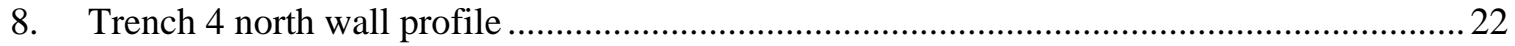

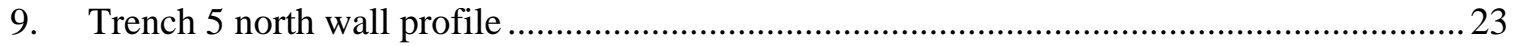

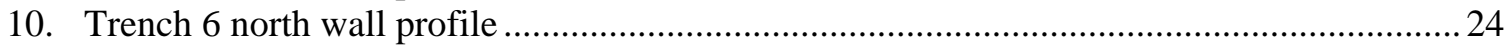

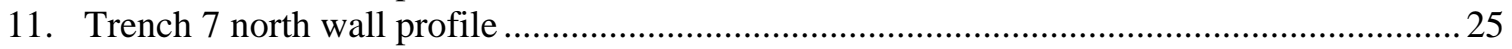

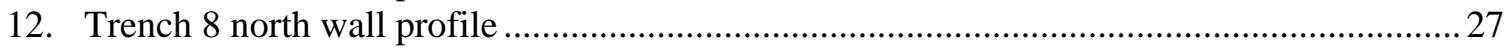

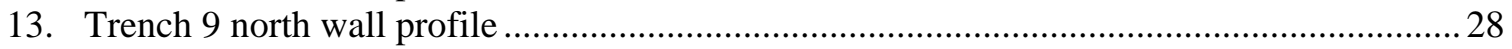

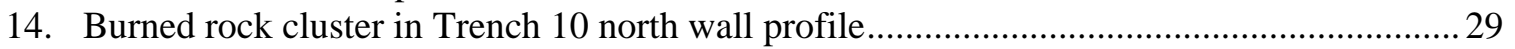

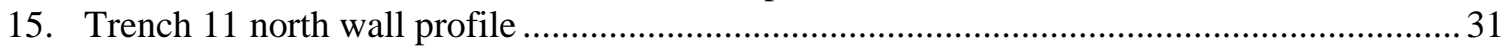

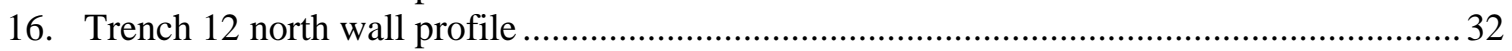

17. Tabular piece of limestone recovered from Trench 13, possible ground stone ...................... 33

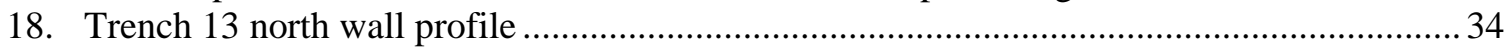

19. Feature 1 rock cluster in Test Unit 4, photographer is facing north-northwest ....................... 38

20. Basal fragment of a biface recovered in Test Unit 4, Level 1 (99.36-99.26 m) .................... 39

21. Profile of the northeast wall of Trench 10, site 41BT427 ................................................. 40

22. Dart point fragment recovered from Test Unit 5, Level $2(99.26-99.16 \mathrm{~m})$....................... 41

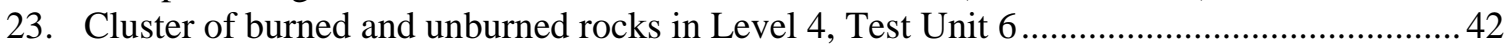

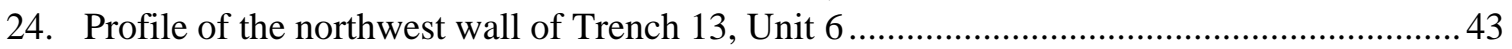

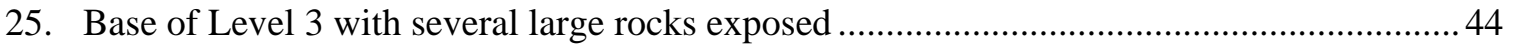





\section{LIST OF TABLES}

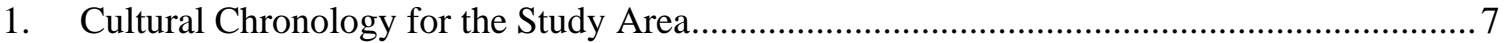

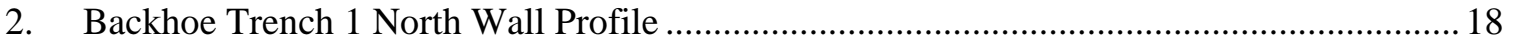

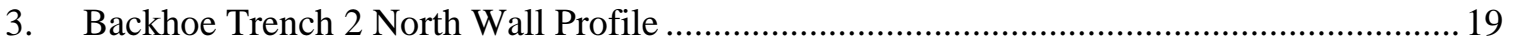

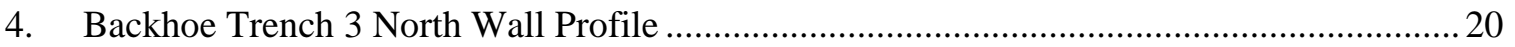

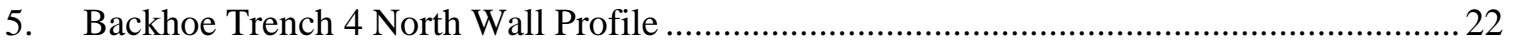

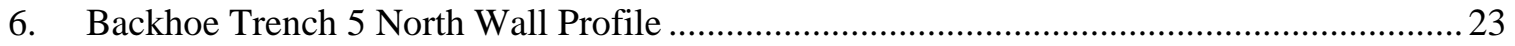

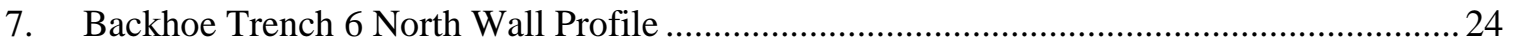

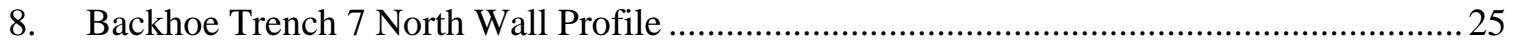

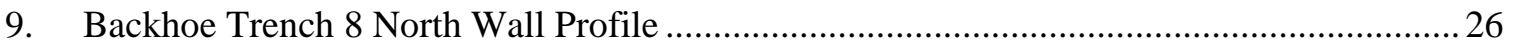

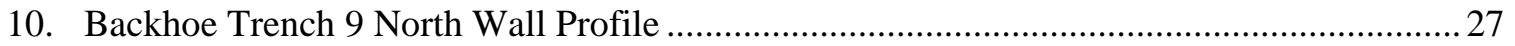

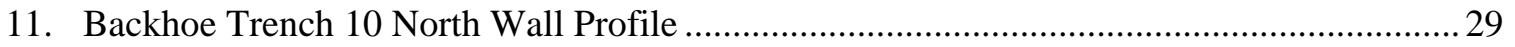

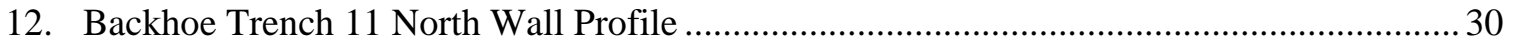

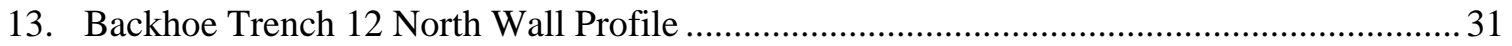

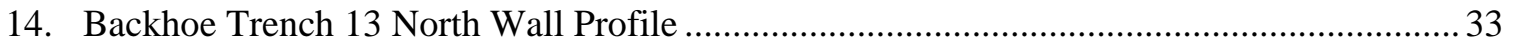

15. All Artifact Types Identified from All Proveniences at 41BT427 ........................................ 35

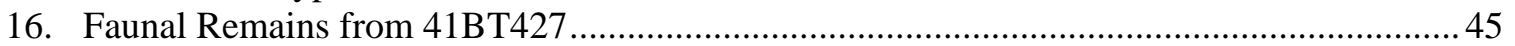

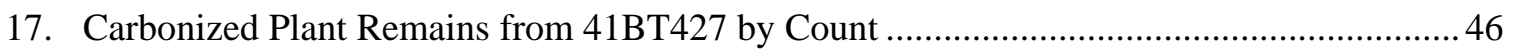

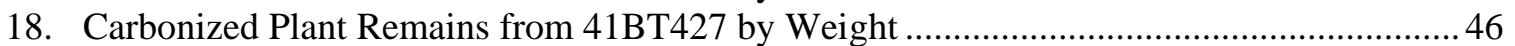

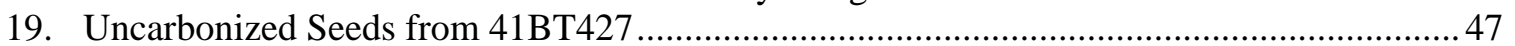

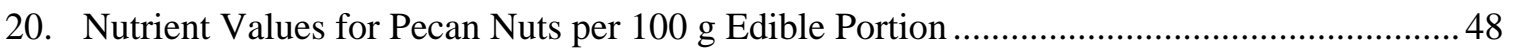

21. 41BT 427 Lithic Debitage Sorted by Size, Raw Material, and Heated ................................ 49

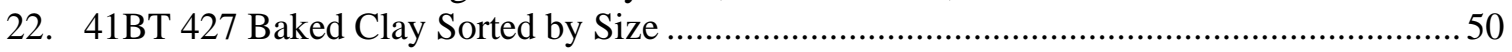

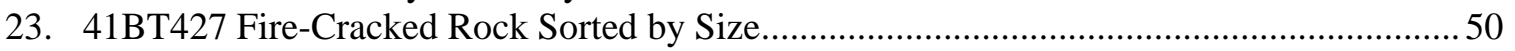





\section{ACKNOWLEDGEMENTS}

The successful completion of the testing work at site 41BT427 would not have been possible without the opportunity and guidance provided by the Texas Department of Transportation, Environmental Affairs Division, archeologist Jon Budd. Geo-Marine's testing at site 41BT427 was carried out by Jennifer Anderson, Lana Martin, Bethany Oliver, and Matt Cuba under the supervision of Project Archeologist Tiffany Osburn and Principal Investigator Missi Green.

In the Geo-Marine laboratory, Steve Hunt and Bethany Oliver processed and recorded all excavated materials. Paleobotanical analyses were performed by Leslie Bush, Ph.D. Erin King produced the maps and diagrams in the report, and Sharlene Allday edited the text. Formatting and document production were handled by Denise Pemberton. Without their efforts, this project would not have been possible. 



\section{CHAPTER 1 INTRODUCTION}

Texas Department of Transportation (TxDOT) proposes to replace the existing bridge and approaches along FM 963 at North Rocky Creek (CSJ 1198-02-017) in Burnet County, Texas. Cultural resources testing is required to comply with Section 106 of the National Historic Preservation Act (NHPA) of 1969, as amended (Public Law [PL] 89-665), the Department of Transportation Act of 1966 (P.L. 89-670), and the Texas Antiquities Code (TAC), as incorporated into Title 98, Chapter 191, of the Natural Resources Code of Texas of 1977, as amended.

Site 41BT427, which is within the area of potential effects (APE) of the TxDOT project, was originally recorded in July 2007 by archeologists from PBS\&J during a pedestrian survey of FM 963 for TxDOT (Nichols and Farabough 2007). Because the site will be affected by the proposed construction, TxDOT Environmental Affairs Division (TxDOT-ENV) contracted with GeoMarine, Inc. (GMI), under contract/work authorization \#57902SA005 to conduct National Register of Historic Places (NRHP) eligibility testing at site 41BT427. GMI archeologists conducted the testing investigations between October 1 and October 19, 2007 (GMI project number 22005.00.02). This current program of testing involved the excavation of a series of trenches on all four quadrants of the intersection of North Rocky Creek and FM 963, where feasible, within the APE (Figure 1). The APE is defined as the existing 80-foot wide right-ofway (ROW) and extending 400 feet on either side of the water line. The work was conducted under TAC permit \#4669, and this report details the results of the investigations.

Thirteen trenches were dug within the project APE: nine survey trenches in the northwest, southwest, and southeast quadrants outside the known boundary of site 41BT427, and four trenches within the site itself in the northeast quadrant. The current investigation within site 41BT427 involved the mechanical excavation of the four trenches (29.5 linear meters) and the hand excavation of eight test units (8.94 cubic meters) within the site boundary. In addition to site testing, survey trenching of the proposed borrow area-the remaining three quadrants, with an additional test unit south of the known site boundary-that was not completed during the initial PBS\&J cultural resources survey was conducted as a part of this GMI investigation. 


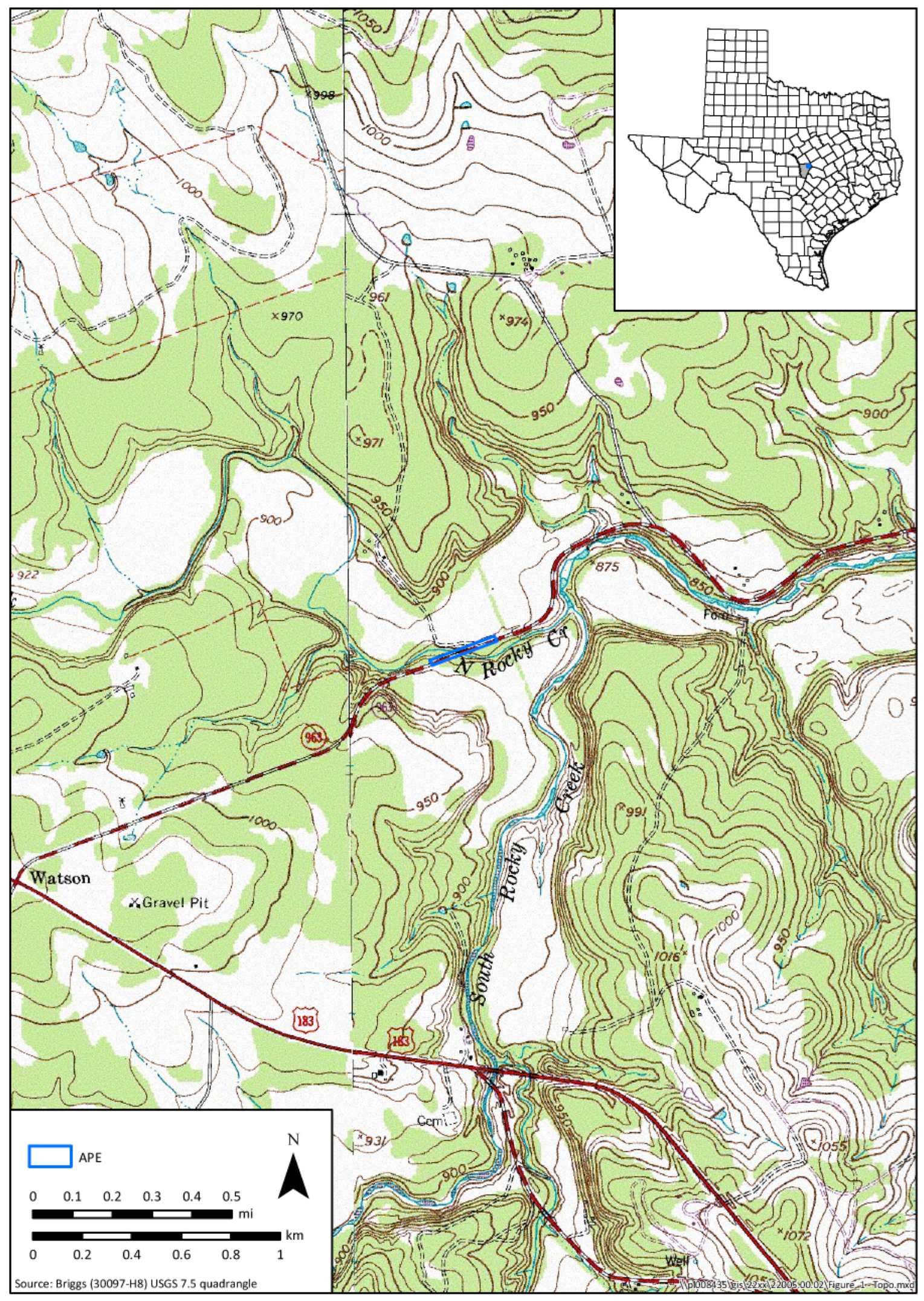

Figure 1. Location of the APE in Burnet County. 


\section{CHAPTER 2 ENVIRONMENTAL SETTING}

\section{INTRODUCTION}

Site 41BT427 is located along North Rocky Creek (a tributary of the Lampasas River) within the Lampasas Cut Plain of the Edwards Plateau region of Central Texas. The Lampasas Cut Plain is essentially a northern extension of the Edwards Plateau (Johnson 2001). The topographic pattern of the plain, however, is entirely different from much of the Edwards Plateau because the dissection in the Lampasas Cut Plain is less severe. The region is characterized by mesa-type topography with wide lowlands intervening between the mesa uplands.

\section{GEOLOGY AND SOILS}

The flat-topped mesas of the region are capped with hard limestone, and the edges are margined by a typical rim-rock vegetation. The lowlands may have somewhat sloping surfaces, in which case, they usually are erosional and underlain with shallow caliche, or they may be completely reduced to flatness, in which case, they have a smooth constructional surface and thick soils (Johnson 2001). The Lampasas River is a major tributary of the Brazos River with a narrow valley of mapped Holocene alluvium less than 1 kilometer ( $\mathrm{km} ; 0.6$ mile [mi]) wide. The soils in the project area are mapped as Oakalla silty clay loam (Figure 2), occasionally flooded (U.S. Department of Agriculture, Natural Resources Conservation Service [USDA, NRCS] 2010a). This soil unit is characterized as alluvium derived from limestone and is found on floodplains.

\section{VEGETATION}

The vegetation of the Lampasas Cut Plain is characterized by deciduous woodlands of Texas oak (Quercus spp.) and deciduous riparian forests of sugarberry (Celtis laevigata) and elm (Ulmus $L$.) (Johnson 2001). A mosaic of grasslands and woodlands characterizes the vegetation of the project area. Grasslands are mixed prairie, with tall, medium, and short grasses present. Upland trees and shrubs typically grow in mottes of oaks, juniper (Juniperus spp.), and agarito (Mahonia trifoliata). Yaupon (Ilex vomitoria) and deciduous holly (Ilex spp.), elbowbush (Forestiera pubescens), persimmon (Diospyros texana), and sumac (Rhus trilobata) are common small trees 


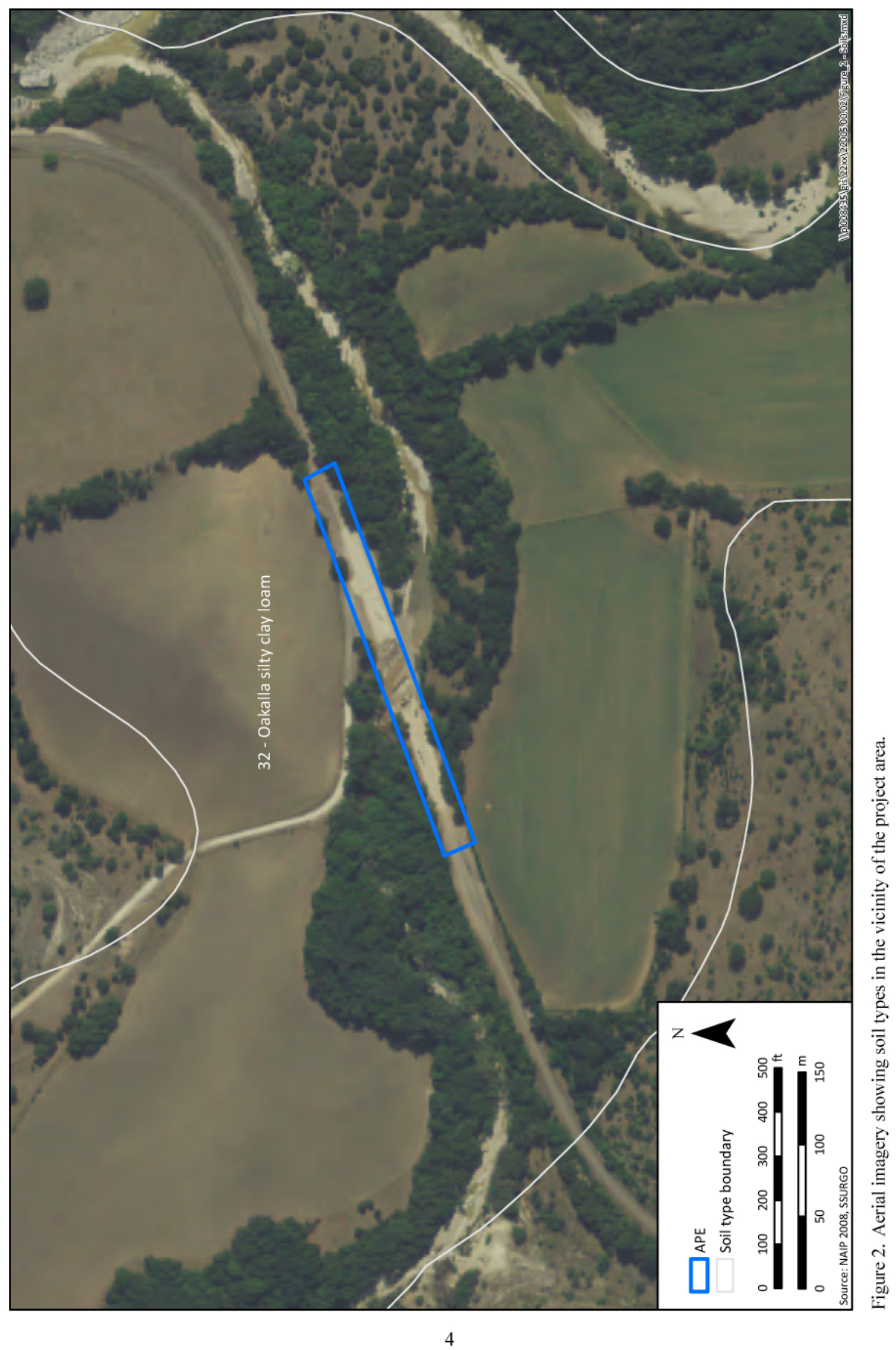


and shrubs. Moister areas along streams and mesic slopes support trees such as sycamore (Platanus occidentalis), pecan (Carya illinoinensis), hackberry (Celtis spp.), and elm (Beaty 1978; Riskind and Diamond 1988)

\section{FAUNA}

Site 41BT427 occupies an area at the intersection of the Edwards Plateau and Cross Timbers vegetation areas, creating a rich habitat for a variety of fauna. Native mammals common to the region in the prehistoric period include opossum (Didelphis virginiana), eastern mole (Scalopus aquaticus), eastern fox squirrel (Sciurus niger), pocket gopher (Geomys breviceps), hispid cotton rat (Sigmodon hispidus), eastern cottontail rabbit (Sylvilagus floridanus), coyote (Canis latrans), grey fox (Urocyon cinereoargenteus), mink (Mustela vison), muskrat (Ondata zibethica), raccoon (Procyon lotor), stripped skunk (Mephitis mephitis), white-tailed deer (Odocoileus virginianus), bison (Bison bison), and black bear (Ursus americanus) (Burt and Grossenheider 1976).

Amphibian and reptilian species of the region include Great Plains rat snake (Elaphe guttata emoryi), eastern yellowbelly racer (Coluber constrictor), yellow mud turtle (Kinosternon flavescan), bullfrog (Rana catesbeiana), and southern leopard frog (Rana utricularia) (Kutac and Caran 1994).

\section{PALEOENVIRONMENT}

Environmental and climatic conditions in Central Texas have changed dramatically since the terminal Pleistocene. Bryant and Holloway (1985) depict the Central Texas region as being dominated by deciduous forest until approximately 10,000 years ago. However, both Hall and Valastro (1995) and Toomy et al. (1993) argue that the region was primarily mesic grassland. The grassland hypothesis is supported in part by the megafauna recorded for the area during the late Pleistocene. Species such as mastodon, mammoth, giant bison, camel, and horse would have required extensive grassland resources (Dillehay 1974; Graham 1987; Toomey et al. 1993).

Subsequent to 10,000 years ago, climatic evidence suggests a gradual drying period with reduced ground cover vegetation (Toomey et al 1993). The general drying trend that began during the late Pleistocene is seen by Toomey et al. (1993) as continuing into the middle and late Holocene with a peak at approximately 5,000-2,500 years ago. Wetter and warmer conditions were resurgent in the region until approximately 1,500-1,000 years ago (Bryant and Holloway 1985; Johnson and Goode 1994). Conditions consistent with modern climatic trends were established from this point forward in Central Texas. 



\section{CHAPTER 3 \\ REGIONAL CULTURAL HISTORY AND PREVIOUS INVESTIGATIONS}

\section{REGIONAL CULTURAL HISTORY}

Several current regional chronologies (Black 1989; Collins 1995; Johnson and Goode 1994) are utilized in the following discussion of Central Texas prehistory. The regional chronology is divided into three basic periods: Paleoindian, Archaic, and Late Prehistoric, each of which is further subdivided in the following discussion (Table 1).

\begin{tabular}{lc}
\multicolumn{2}{c}{ Table 1 } \\
Cultural Chronology for the Study Area \\
Period & Date \\
\hline Paleoindian & $10,000-6800$ B.C. \\
Archaic & 6800 B.C. - A.D. 750 \\
Early Archaic & $6800-4000$ B.C \\
Middle Archaic & $4000-2000$ B.C. \\
Late Archaic & 2000 B.C. - A.D. 750 \\
Late Prehistoric & A.D. $750-1540$ \\
Austin Interval & A.D. $500-1200$ \\
Toyah Interval & A.D. $1200-1540$ \\
Historic & A.D. $1540-1900$ \\
\hline
\end{tabular}

After Black 1989; Collins 1995; Johnson and Goode 1994 


\section{Prehistoric Cultural Chronology}

\section{Paleo-Indian (10,000-6800 B.C.)}

Human occupation in Central Texas is generally agreed to have begun during the terminal Pleistocene. This initial Paleo-Indian cultural period is dated to approximately 10,000-6800 B.C. (Black 1989; Collins 1995, 2004; Johnson and Goode 1994). In Central Texas, the Paleo-Indian period is divided into Early (10,000-8900 B.C) and Late (8900-6800 B.C.) subperiods. The Early Paleo-Indian period is characterized by fluted Clovis projectile points along with prismatic blade manufacture. Subsistence during this subperiod appears to have been diverse and consisted of both megafauna (e.g., mammoth and extinct large bison) as well as smaller taxa such as badger, alligator and moles (Collins et al. 1989). Prominent sites in the region with Early Paleo-Indian components include the Kincaid Rockshelter, Wilson-Leonard, and Gault sites. The Late PaleoIndian continued with a mixed hunting-gathering tradition and is characterized by the Folsom and Plainview point types (Collins 1998). Burned rock features made their first appearance in Central Texas during the Late Paleo-Indian period (Masson and Collins 1995). Sites of note in the region with Late Paleo-Indian components include Wilson-Leonard, Golondrina-Barber, and St. Mary's Hall.

Archaic (6800 B.C.-A.D. 750)

Johnson and Goode's (1994) formulation of the Central Texas Archaic makes use of three subdivisions: Early Archaic (6800-4000 B.C.), Middle Archaic (4,000-2000 B.C.), and Late Archaic (2,000 B.C.-A.D. 750) based on point typologies.

\section{Early Archaic (6800-4000 B.C.)}

The Early Archaic in Central Texas is most known for its large burned rock midden sites that commonly constitute multiple tons of fire-cracked rock. Although burned rock middens are first noted in the Late Paleo-Indian period for Central Texas, they became a prominent site type by the Early Archaic. The Early Archaic is generally defined by three projectile point style intervals: Angostura, Early Split-stem, and Martindale-Uvalde (Johnson and Goode 1994). In addition to burned rock middens, site types include open campsites (Loeve, Wilson-Leonard, and RichardBeene) and caves (Hall's Cave). Subsistence evidence for the Early Archaic is varied, with deer, small animal, fish, and plant bulb being common taxa. Pollen and fluvial geological evidence suggest that environmental conditions during the period fluctuated between mesic and xeric conditions (Collins 2004).

\section{Middle Archaic (4000- 000 B.C.)}

Bell/Andice/Calf Creek, Taylor, and Nolan/Travis constitute the three projectile point styles indicative of the Middle Archaic period (Johnson and Goode 1994). The Bell/Andice/Calf Creek point technology along with environmental data suggesting mesic conditions are seen by Collins (1994) as evidence for a focus on bison hunting. However, by the latter portion of the Middle Archaic, environmental conditions appear to have shifted again to being more xeric. The xeric 
conditions of the latter Middle Archaic have been correlated with an increase in burned rock midden deposits, and this association is believed to have been due to a greater reliance upon tuberous plants such as sotol iris (Johnson and Goode 1994).

\section{Late Archaic (2000 B.C.-A.D. 750)}

According to Johnson and Goode (1994), the Late Archaic for Central Texas can be subdivided into (ascending chronological order) six style intervals: Bulverde, Pedernales/Kinney, Lange/Marshall/Williams, Marcos/Montell/Castroville, Ensor/Frio/Fairland, and Darl. The Late Archaic in Central Texas began with xeric conditions and progressively became more mesic. Burned rock midden deposits continue to be a significant part of many site assemblages and actually peak in density during the Pedernales/Kinney interval (Collins 2004). Dart points, corner-tanged knives, and cylindrical stone pipes are associated with Late Archaic site assemblages from Central Texas. A mixed hunting-gathering economy of large and small animals as well as various reliable plants of the region (e.g., stool iris and pecan) became well developed by the end of the Late Archaic and continued largely unchanged into the early Late Prehistoric.

\section{Late Prehistoric (A.D. 750-1540)}

The Late Prehistoric period of the region is divided into Early (Austin interval) and Late (Toyah interval) subperiods (Collins 2004; Johnson and Goode 1994). The evolution to the Late Prehistoric period in Central Texas is signaled by the introduction of bow and arrow technology that occurs during the Austin interval. Although the arrow point made its introduction in the Late Prehistoric, it is initially underrepresented when compared to dart points. The later Toyah interval of the Late Prehistoric is characterized by the dominance of the arrow point, specifically the Perdiz type. The constellation of Perdiz arrow points, locally manufactured ceramics, end scrapers, and prismatic blades is seen as an indication of a focus on large game animals (e.g., bison, deer, and antelope). Researchers currently disagree on whether this artifact assemblage represents a techno-complex (Ricklis 1994) or an actual cultural group (Johnson 1994).

\section{Historic Period (A.D. 1540-1900)}

The Historic period began with the arrival of the first Europeans in the area, Coronado's 15401542 expedition to the Plains of Cíbola, the High Plains west of the study area (Castañeda 1554[1904]). Coronado's chroniclers and those of later Spanish expeditions (e.g., Posada 1686[1982]) report that the region was occupied by Apacha (Apache) people. Based on Spanish descriptions of Apache lifeways - with limited sedentism and a seasonal round of bison hunting and foraging - it seems that the Garza and Toyah archeological complexes may represent early Apache occupations (Boyd 1997). In an alternative interpretation that has not yet gained traction in the Texas archeological community, Garza and other Late Prehistoric and Protohistoric assemblages have also been linked to the Wichita (Baugh and Perkins 2008; Roberts and Bradford 1997). 
If Garza and/or Toyah indeed represent early Apache occupations, the Apache were the primary native group in the area until the early to mid-eighteenth century, when nomadic Comanche hunters arrived from the Great Basin and plains northwest of Texas (Lipscomb 2008). Various Anglo, French, and Spanish traders maintained commercial relationships with the Apache and Comanche, but the locations and timing of these interactions are debated; for instance, sites of the Spanish traders known as comancheros have not been securely identified because "no one is sure what they should look like" (Freeman and Boyd 1997:82). Shoshonean-speaking Comanche continued their presence in Central Texas until the end of the nineteenth century.

The area that was later established as Burnet County formed parts of both the Robertson and Austin-Williams Mexican land-grant colonies. However, at the time of Texas Independence, the majority of the land in the region was still public domain and unsettled (Bowden 1940). With the annexation of Texas by the United States in 1845, the region became an important location on the Comanche frontier with the establishment of the McCulloch's station, and later Fort Croghan. Burnet County was officially formed in 1852 from former parts of Travis, Bell, and Williamson counties (Bowden 1940). By 1860, the county had 2,487 residents and three communities; Smithwick, Oatmeal, and Backbone Valley (Bowden 1940). Cotton agriculture and stock rearing (cattle, sheep, and goats) formed the basis of the Burnet County economy in the nineteenth century and well into the modern period.

\section{PREVIOUS INVESTIGATIONS}

Prehistoric site 41BT427 was originally recorded by PBS\&J during a cultural resources survey for the proposed bridge replacement project at the North Rocky Creek crossing of FM 963 (Nichols and Farabough 2007). The work was conducted in June and July 2007 and included pedestrian survey of the ROW as well as the excavation of four backhoe trenches in the northeastern quadrant. Cultural materials associated with site 41BT427 were identified in two of these trenches (PBSJ Trench 2 and PBSJ Trench 4). Three burned rock features were identified in the trench profiles. No artifacts were observed during that investigation, though mammal bone and charcoal were collected. Feature 1 was identified in PBSJ Trench 2 at a depth of 75 centimeters $(\mathrm{cm})$ below surface (bs) and consisted of a linear concentration of burned limestone rocks with no associated staining or charcoal. Feature 2 was identified in PBSJ Trench 2 at a depth of $180 \mathrm{~cm}$ bs and consisted of a burned rock concentration with associated charcoal and mammal bone. Feature 3 was identified in PBSJ Trench 4 at a depth of $180 \mathrm{~cm}$ bs and contained only two burned rocks above a soil stain.

Trenching within the remaining three quadrants was not completed during the initial cultural resources survey but was undertaken as a part of this current investigation. 


\section{CHAPTER 4 RESEARCH METHODS}

\section{FIELD METHODS}

The first stage of fieldwork consisted of the excavation of 13 backhoe trenches within the APE: four within the boundaries of site 41BT427 and nine survey trenches in the other three quadrants (Figure 3). The backhoe trenches were placed to sample every landform within the APE. Mechanical excavations were conducted with a toothed-bucket to various depths, with an estimated average of $20-30-\mathrm{cm}$ depth intervals. The location of each trench was recorded using aglobal positioning system (GPS) device to record the position of both ends of every trench. Two archeological monitors were present during the trench excavations. The goal of monitoring mechanical excavations was to identify locations where artifact density was high enough to be readily detectable and therefore potentially exploitable for hand excavation. In general, one monitor watched the excavation to control depth and identify in situ materials, while the other monitor watched the backdirt as it was dumped. All trenches were carefully scraped, profiled, and recorded by the Project Archeologist. Standard soil taxonomy methods were used to provide a measured description of a representative wall from each trench. All of the trenches were photographed.

As specified in the scope of work, a series of hand-excavated 1-x-1-m test units was placed adjacent to each of the four trenches at site 41BT427, as well as one test unit adjacent to the trench south of the site (Figure 4). These units were placed on benches excavated adjacent to the trenches. The original survey conducted at this site recorded no cultural material above $75 \mathrm{~cm}$ and no material was identified during the current phase of trenching above this depth. Benches were excavated to approximately $65-75 \mathrm{~cm}$ bs around excavation units. This served to create a safety bench in accordance with Occupational Safety and Health Administration (OSHA) safety standards as well as remove culturally sterile overburden. The test units were excavated in $10-\mathrm{cm}$ arbitrary levels from the level of the bench to depths ranging from 145-240 cm bs. Sediment from the test units was screened through 0.625 millimeter $(\mathrm{mm} ; 0.25$ inch [in]) hardware cloth. All lithic debris, chipped and ground stone tools, bone, and freshwater mussel shell were collected. Rabdotus snails were counted for each level, and burned and unburned rock was weighed and counted. Artifact counts and observations were made on standard unit-level forms. Flotation samples and samples for fine screening were collected from levels containing concentrations of cultural material, feature contexts, and nonfeature contexts in an effort to recover minute charred plant remains and artifacts. 


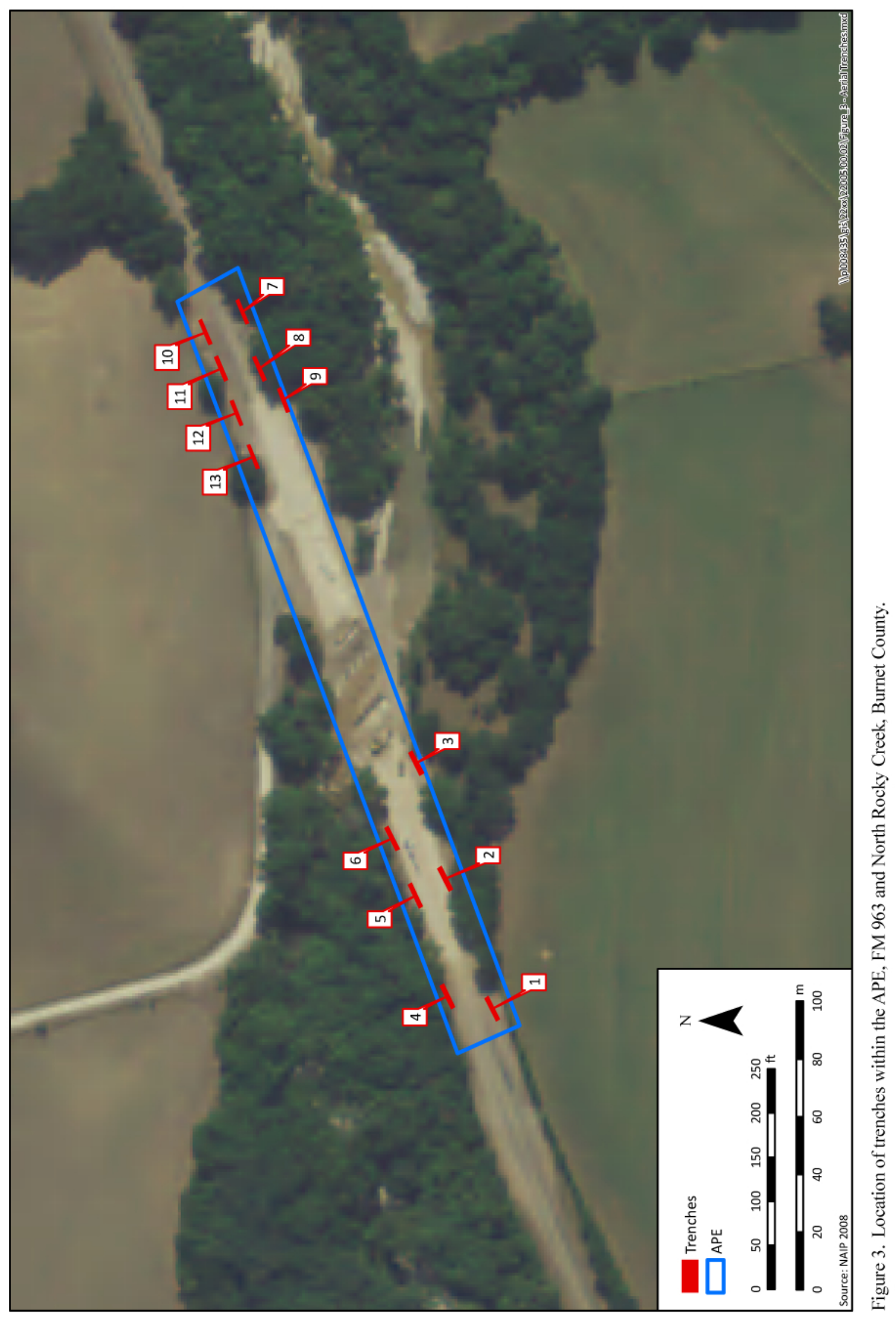




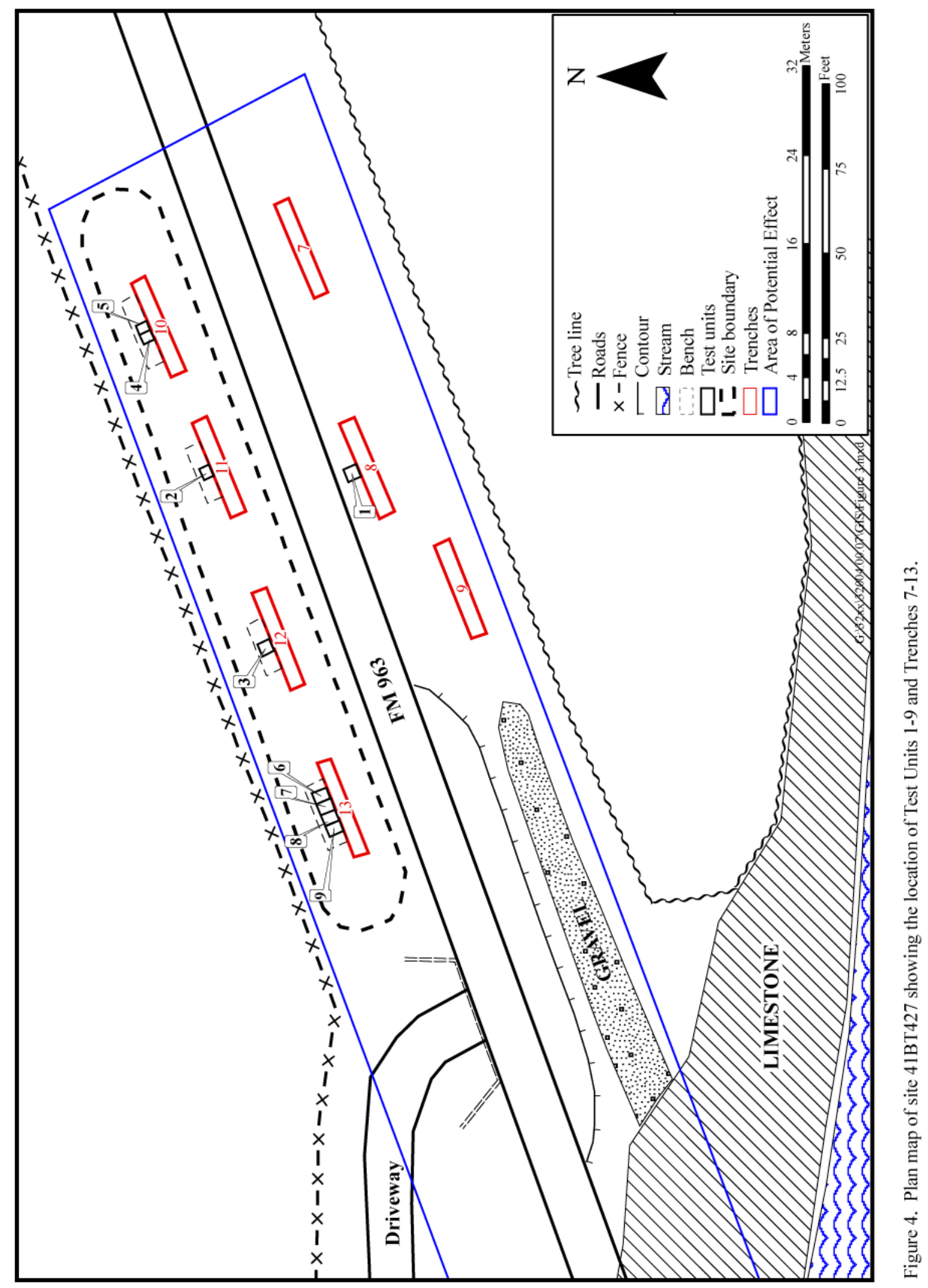


A site map was created using both GPS and total station data. First the Trimble ${ }^{\circledR}$ ProXRS backpack GPS was used to collect locational data for each of the trenches, the road, the edge of the APE, and various other reference points. During later hand excavation, the total station was used to map the location of 1-x-1-m units adjacent to each trench, the datum points for each unit, and the benches, and these data were overlaid with the GPS data to create an accurate map of site 41BT427.

\section{LABORATORY PROCEDURES}

All cultural material recovered during data recovery was returned to the GMI laboratory facilities in Plano, Texas, to be washed, weighed, counted, catalogued, and labeled in compliance with Texas Archeological Research Laboratory (TARL) standards. Context and attribute data for all materials were recorded in a Microsoft ACCESS database on an IBM network system. The main categories of material recovered were animal bone, mussel shell, baked clay, lithics, botanical samples (both flotation samples and opportunistically collected wood charcoal), and fire-cracked rock (Appendix A). All artifactual material was analyzed in the GMI laboratory except the botanical remains, which were sent to an external analyst. The following discussion describes analytical strategies and summarizes the attributes recorded during the analysis of each class of material.

\section{Faunal Remains}

\section{Mammal}

Every attempt was made to identify bone fragments to the highest taxonomic level possible. Bone specimens not bearing diagnostic features but similar in size and other formal characteristics were placed within the following specific size classes: small terrestrial mammal (STM), medium terrestrial mammal (MTM), large terrestrial mammal (LTM), and very large terrestrial mammal (VLTM). Assessments were also made of the following characteristics: bone element, size/weight of fragment, fusion state, rodent gnawing, burning/butchery evidence, number of identifiable specimens (NISP), and standard metric analyses.

\section{Molluscan Shell}

Molluscan specimens were counted using two quantitative units: number of specimens (NSP; [identified and unidentified]) and NISP. Because samples were small, minimum number of individuals (MNI) was not calculated. All attempts were made to identify specimens to taxon and element.

\section{Botanical Remains}

Flotation samples were processed at the GMI Plano offices in a Siraf tank flotation system with bottom mesh openings of $0.5 \mathrm{~mm}$ (Pearsall 2000:Figure 2.21). Flotation and carbon samples were sent to a private contracting firm, Macrobotanical Analysis (Leslie Bush Ph.D., owner) in February 2010 and the full report is contained within Appendix B. 
Flotation samples were sorted according to standard procedures (Pearsall 2000). Each sample was weighed on an Ohaus Scout II 200 x $0.01 \mathrm{~g}$ electronic balance before being size-sorted through a stack of graduated geologic mesh. Materials that did not pass through the No. 10 mesh (2-mm square openings) were completely sorted. At 41BT427, only three categories were present that were larger than $2 \mathrm{~mm}$ : carbonized macrobotanical remains, identifiable bones, and contamination. The "contamination" (i.e. not studied by the paleobotanist) category includes uncarbonized botanical remains such as rootlets and hackberry seeds, gastropod and bivalve shells, soil clumps, and rocks. All carbonized botanical remains and identifiable bones were counted, weighed, recorded, and labeled. Contamination was weighed, recorded, and labeled only. Materials that fell through the 2-mm mesh ("residue") were examined under a stereoscopic microscope at 7-45 X magnification for carbonized botanical remains. Identifiable material was removed from residue, counted, weighed, recorded, and labeled. Although wood charcoal smaller than $2 \mathrm{~mm}$ is not usually removed from residue, so little wood charcoal was present in three of the samples that wood charcoal greater than $0.7 \mathrm{~mm}$ was removed from Field Specimen (FS) \#60 and FS\#61, and wood charcoal greater than $1.4 \mathrm{~mm}$ was removed from FS\#65. Uncarbonized macrobotanical remains were recorded on a presence/absence basis on laboratory forms.

For each flotation sample, wood charcoal fragments were selected at random for identification. Fragments were snapped to reveal a clean transverse section and examined under a stereoscopic microscope at 28-180 X magnification. When necessary, tangential or radial sections were examined for ray seriation, presence of spiral thickenings, types and sizes of intervessel pitting, and other minute characteristics that can only be seen at the higher magnifications of this range.

Botanical materials were identified to the lowest possible taxonomic level by comparison to materials in the Macrobotanical Analysis comparative collection and through the use of standard reference works (e.g., Core et al. 1979; Davis 1993; Hoadley 1990; Martin and Barkley 1961; Musil 1963; Panshin and de Zeeuw 1980). Plant nomenclature follows that of the PLANTS Database (USDA, NRCS 2010b).

\section{Chipped Stone Tools and Debitage}

The major prehistoric artifact class identified in the lithic analysis was lithic debitage. Of the 105 lithic artifacts collected, all but two were various pieces of flaking debris. Two bifaces, one of which is a projectile point base, were recovered during the excavation. No ground, pecked, or battered stone tools were found.

The lithic debitage was classified by technological reduction source (i.e., core flake, biface flake, flake fragment, and shatter). Variables recorded for the lithic debitage included the technological type of debitage, amount of dorsal cortex (if present), heat-treatment or burning, material type, size range, and weight.

\section{Baked Clay}

Irregular, gravel-sized masses of hardened clay, many with evidence of oxidation, reduction, or smudging due to fire, occurred in limited amounts in cultural levels in test units. A basic analysis of these masses was performed in the GMI laboratory, where they were separated by size 
categories. These categories included the following size classes: smaller than 0.5 in $(12.7 \mathrm{~mm})$, $0.5-1$ in $(12.7-25.4 \mathrm{~mm}), 1-1.5$ in $(25.4-38.1 \mathrm{~mm}), 1.5-2$ in $(38.1-50.8 \mathrm{~mm})$, and larger than 2 in $(50.8 \mathrm{~mm})$. The cumulative weight and total number of baked clay masses within each class and within each context were then recorded in the project ACCESS database.

\section{Fire-Cracked Rock}

Fire-cracked rock (FCR) was subjected to a similar basic analysis in the GMI laboratory. Fragments were first sorted based by rock material type (e.g., limestone, quartzite, etc.), and any direct evidence of heating (e.g., fracture pattern, discoloration) noted. Within material types, the FCR was then sorted into size classes: smaller than 0.5 in $(12.7 \mathrm{~mm}), 0.5-1$ in $(12.7-25.4 \mathrm{~mm})$, $1-1.5$ in $(25.4-38.1 \mathrm{~mm}), 1.5-2$ in $(38.1-50.8 \mathrm{~mm}), 2-4$ in $(50.8-101.6 \mathrm{~mm}), 4-6$ in $(101.6-$ $152.4 \mathrm{~mm})$, and larger than 6 in $(152.4 \mathrm{~mm})$. In the end, the final size class was not included in the analysis because no FCR fragments larger than 6 in $(152.4 \mathrm{~mm})$ were found. The cumulative weight and total number of FCR fragments within each class and within each archeological context were then recorded in the project ACCESS database.

\section{CURATION}

Upon completion of the analyses and reporting, collected materials will be assessed for the appropriateness for long-term curation.

The remaining collections from the project will be prepared for curation according to the packaging guidelines established by TARL at the University of Texas, Austin. Field and laboratory forms will be on acid-free paper; negatives and photographs will be labeled and placed in acid-free holders; cleaned and labeled artifacts will be placed in appropriate bags and boxes suitable for long-term storage. An inventory of materials submitted to curation will be prepared and a copy will be sent with the collection to TARL for long-term storage; other copies will be sent to TxDOT-ENV. 


\title{
CHAPTER 5 RESULTS OF THE TEST EXCAVATIONS
}

\author{
EXCAVATIONS
}

\section{Trench Excavations}

Four trenches (Trenches 10-13) were excavated within the boundary of site 41BT427 and nine survey trenches (Trenches 1-9) were excavated along the ROW in the remaining three quadrants of North Rocky Creek and FM 963 (see Figure 3). The nine trenches excavated in the southeast, southwest, and northwest quadrants did not yield cultural material. Trenching within site 41BT427 totaled 29.5 linear meters. All of the trench descriptions are provided below.

\section{Trench Descriptions}

\section{Trench 1}

Trench 1 was excavated in the southwestern quadrant farthest from the creek. This trench was excavated to a maximum depth of $160 \mathrm{~cm}$ bs before encountering limestone bedrock. The total length of Trench 1 was $7 \mathrm{~m}$. Generally, the deposits recorded in this trench indicate a sequence of overbank deposits (Table 2, Figure 5). Gravel lenses in Horizons III and V indicate periods of high-energy flow. No cultural deposits or buried soils were identified.

\section{Trench 2}

Trench 2 was also excavated in the southwestern quadrant of the APE. This trench reached a total length of $6 \mathrm{~m}$ and was excavated to a maximum depth of $160 \mathrm{~cm}$ bs before encountering limestone bedrock and regolith. No cultural materials or buried soil horizons were encountered in this trench. This trench also records a sequence of overbank deposits including high-energy deposition containing gravels in Horizon III (Table 3, Figure 6). 
Table 2

Backhoe Trench 1 North Wall Profile

\begin{tabular}{|c|c|c|c|}
\hline Horizon & $\begin{array}{r}\text { Depth } \\
(\mathrm{cm} \mathrm{bs})\end{array}$ & Soil Description & Contents \\
\hline I & $0-20$ & $\begin{array}{l}\text { Brown (10YR 4/3) medium silty loam with a medium blocky } \\
\text { structure, sticky, plastic with no mottles, common roots, and a } \\
\text { gradual smooth boundary }\end{array}$ & Sterile \\
\hline II & $20-60$ & $\begin{array}{l}\text { Brown (10YR 4/3-4/4) medium silty clay loam, moderately } \\
\text { common 1-cm pea gravels, moderately friable, friable, plastic with } \\
\text { no mottles, common fine roots, clear smooth boundary }\end{array}$ & Sterile \\
\hline III & $60-72$ & $\begin{array}{l}\text { Yellowish brown (10YR 5/4) gravel lens with coarse sands, hard, } \\
\text { friable, non-sticky, non-plastic, no roots, and a clear smooth } \\
\text { boundary }\end{array}$ & Sterile \\
\hline IV & $72-90$ & $\begin{array}{l}\text { Dark yellowish brown (10YR 4/4) silty clay, compact, sticky, } \\
\text { plastic, few roots, with common } \mathrm{CaCO}_{3} \text { filaments, with a clear } \\
\text { smooth boundary }\end{array}$ & Sterile \\
\hline $\mathrm{V}$ & $90-110$ & $\begin{array}{l}\text { Yellowish brown (10YR 5/4) gravel lens with coarse sands, hard, } \\
\text { friable, non-sticky, non-plastic, no roots, and a clear smooth } \\
\text { boundary }\end{array}$ & Sterile \\
\hline VI & $110-125$ & $\begin{array}{l}\text { Yellowish brown (10YR 5/4) silty clay with common } \mathrm{CaCO}_{3} \\
\text { filaments, gradual diffuse boundary }\end{array}$ & Sterile \\
\hline VII & $125-150$ & $\begin{array}{l}\text { Yellowish brown (10YR 5/4) silty clay loam, non-sticky, plastic, } \\
\text { clear abrupt boundary }\end{array}$ & Sterile \\
\hline VIII & $150-160$ & Sand and gravel up to $3 \mathrm{~cm}$ & Sterile \\
\hline IX & $160+$ & Limestone bedrock & Sterile \\
\hline
\end{tabular}

\section{Trench 3}

Trench 3 was also excavated in the southwestern quadrant nearest North Rocky Creek. This trench was $7 \mathrm{~m}$ in length and was excavated to a maximum depth of $180 \mathrm{~cm}$ bs. At $176 \mathrm{~cm} \mathrm{bs}$, sand and gravel deposits were encountered that began caving in and undercutting the trench walls; excavation was halted so that trench recording could proceed safely. No cultural material was identified, and no buried soil horizons are present in this location. Stream deposits dominate the profile as would be expected for the floodplain of the North Rocky Creek (Table 4, Figure 7).

\section{Trench 4}

Trench 4 was excavated in the northwestern quadrant of the APE. This trench was $7.5 \mathrm{~m}$ long and was excavated to a maximum depth of $167 \mathrm{~cm}$ bs before encountering gravel overlying limestone bedrock. The upper two horizons visible in the trench wall consisted of fill, likely resulting from road construction (Table 5, Figure 8). No cultural material was identified and no buried soil was detected. 


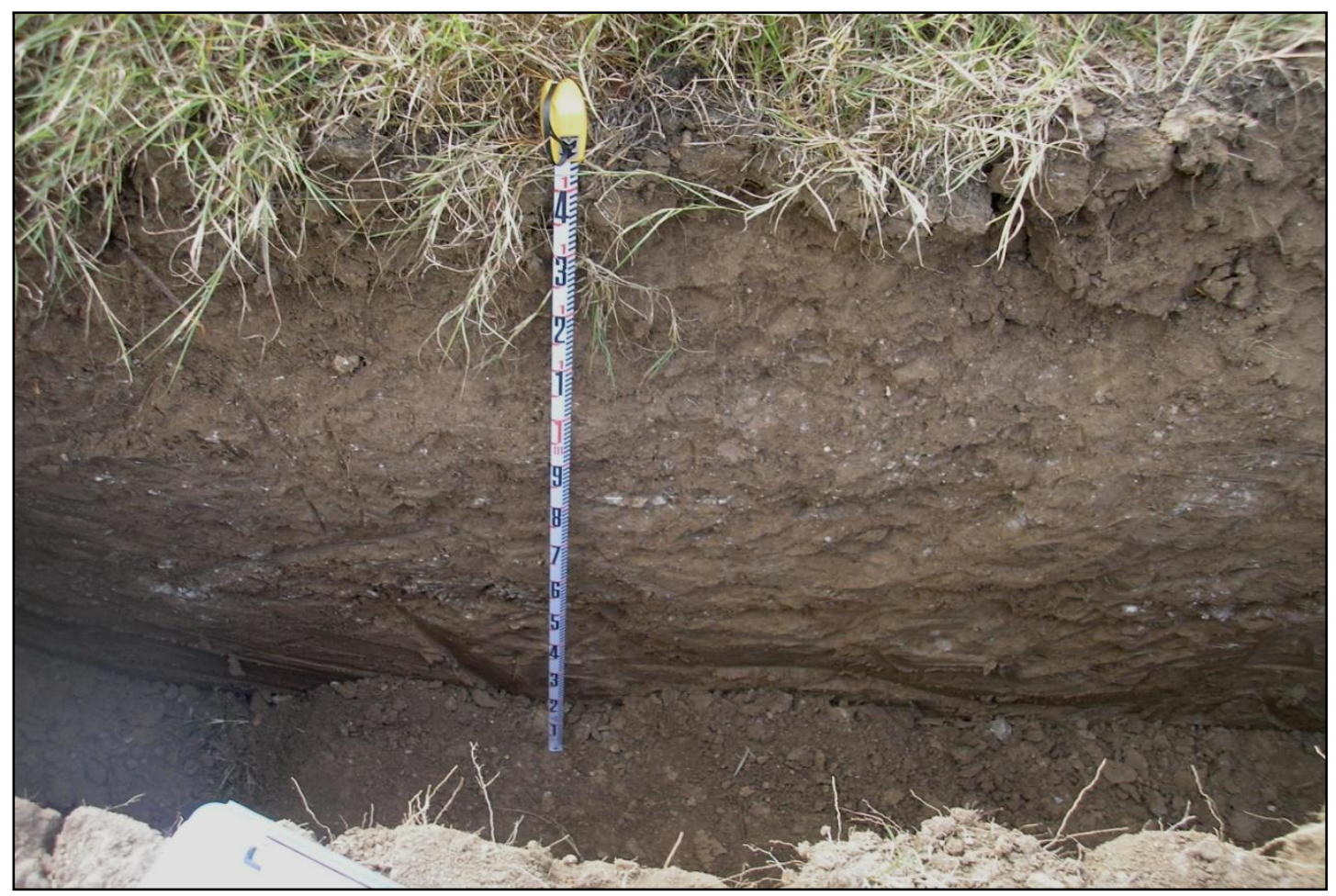

Figure 5. Trench 1 north wall profile.

Table 3

Backhoe Trench 2 North Wall Profile

\begin{tabular}{|c|c|c|c|}
\hline Horizon & $\begin{array}{r}\text { Depth } \\
(\mathrm{cm} \mathrm{bs})\end{array}$ & Soil Description & Contents \\
\hline I & $0-30$ & $\begin{array}{l}\text { Very dark gray (10YR 3/1) silty clay loam with a medium blocky } \\
\text { structure, sticky, plastic with no mottles, common roots, and a } \\
\text { gradual smooth boundary }\end{array}$ & Sterile \\
\hline II & $30-60$ & $\begin{array}{l}\text { Dark grayish brown (10YR 4/2) silty loam, no structure, } \\
\text { moderately common }<1-\mathrm{cm} \text { pea gravels, moderately friable, } \\
\text { friable, common fine roots, clear smooth boundary }\end{array}$ & Sterile \\
\hline III & $60-90$ & $\begin{array}{l}\text { Brown (10YR 4/3) silty loam with gravels, gradual fining } \\
\text { upward, granular, friable, non-sticky, non-plastic, no roots, } \\
\text { gravel lens at base with discrete boundary }\end{array}$ & Sterile \\
\hline IV & $90-150$ & $\begin{array}{l}\text { Brown (10YR 5/3-4/3) silty loam, granular, friable, no structure, } \\
\text { common } \mathrm{CaCO}_{3} \text { filaments, with a clear smooth boundary }\end{array}$ & Sterile \\
\hline $\mathrm{V}$ & $150-160$ & Coarse limestone sand and gravel above regolith & Sterile \\
\hline
\end{tabular}




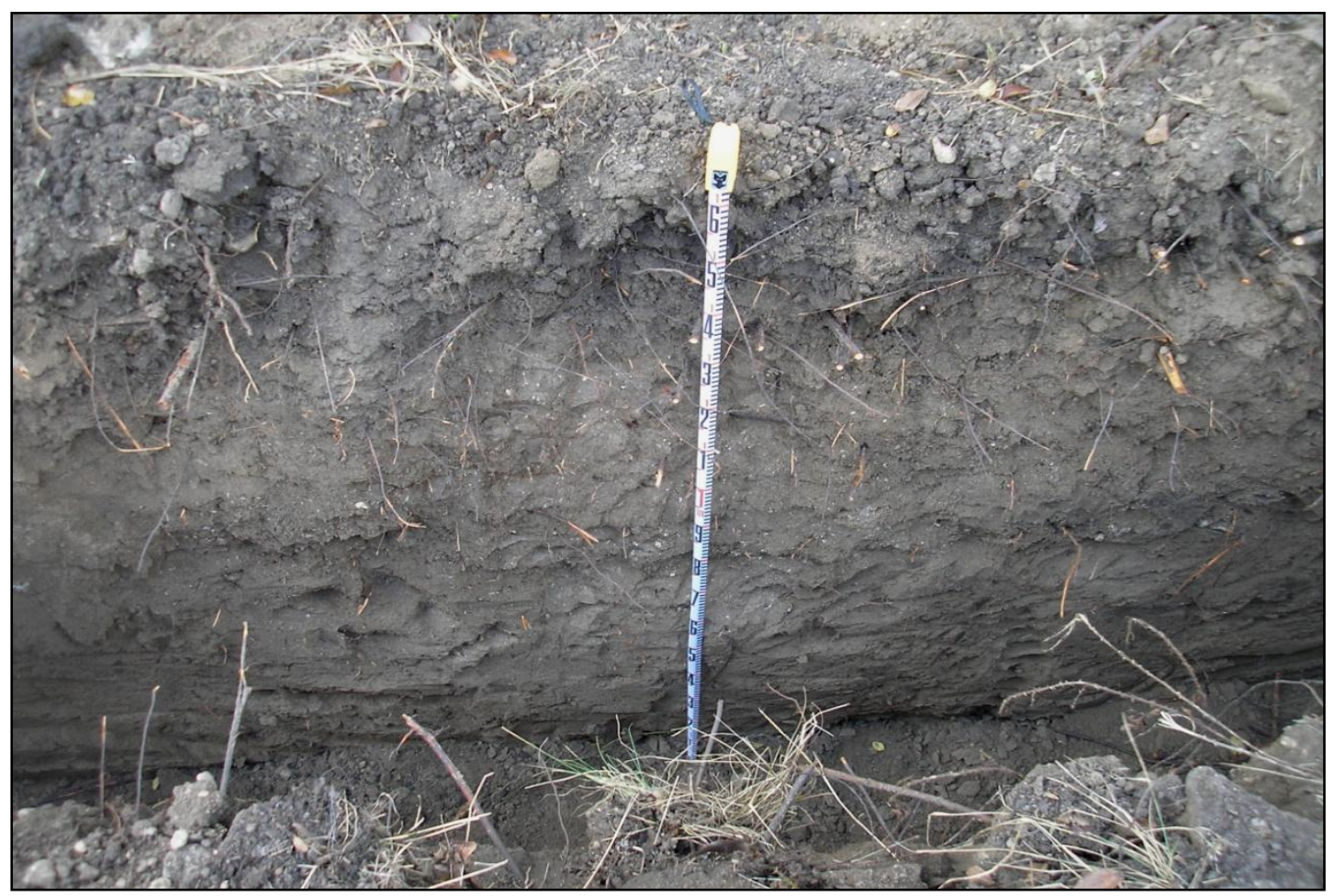

Figure 6. Trench 2 north wall profile.

Table 4

Backhoe Trench 3 North Wall Profile

\begin{tabular}{|c|c|c|c|}
\hline Horizon & $\begin{array}{r}\text { Depth } \\
(\mathrm{cm} \mathrm{bs})\end{array}$ & Soil Description & Contents \\
\hline I & $0-20$ & $\begin{array}{l}\text { Very dark grayish brown (10YR } 3 / 2) \text { mixed fill including gravel } \\
\text { and clay clasts, common roots, clear abrupt boundary }\end{array}$ & Sterile \\
\hline II & $20-30$ & $\begin{array}{l}\text { Dark grayish brown (10YR 4/2) fill with some gravels, common } \\
\text { fine roots, clear smooth boundary }\end{array}$ & Sterile \\
\hline III & $30-57$ & $\begin{array}{l}\text { Dark grayish brown }(10 \mathrm{YR} 4 / 2) \text { coarse mixed sand and silt with } \\
\mathrm{CaCO}_{3} \text { in interstices, no structure, some very small gravels, } \\
\text { non-plastic, few roots, and a clear smooth boundary }\end{array}$ & Sterile \\
\hline IV & $57-105$ & $\begin{array}{l}\text { Brown (10YR 4/3) silty loam, compact, non-plastic, few roots, no } \\
\text { structure, with a diffuse boundary }\end{array}$ & Sterile \\
\hline $\mathrm{V}$ & $105-121$ & $\begin{array}{l}\text { Yellowish brown (10YR 5/4) coarse sand, friable, non-sticky, } \\
\text { non-plastic, no roots, and a clear smooth boundary }\end{array}$ & Sterile \\
\hline VI & $121-145$ & $\begin{array}{l}\text { Gray }(10 \mathrm{YR} 5 / 1) \text { silty clay with common } \mathrm{CaCO}_{3} \text { filaments and } \\
\text { redox staining, clear boundary }\end{array}$ & Sterile \\
\hline VII & $145-150$ & $\begin{array}{l}\text { Light yellowish brown (10YR 6/4) sand, non-sticky, non-plastic, } \\
\text { clear abrupt boundary }\end{array}$ & Sterile \\
\hline VIII & $150-165$ & Dark gray (10YR 4/1) clay, plastic, abrupt boundary & Sterile \\
\hline IX & $165-170$ & $\begin{array}{l}\text { Light yellowish brown (10YR 6/4) sand, non-sticky, non-plastic, } \\
\text { clear abrupt boundary }\end{array}$ & Sterile \\
\hline
\end{tabular}


Table 4 (cont'd)

\begin{tabular}{crll} 
Horizon & $\begin{array}{c}\text { Depth } \\
(\mathrm{cm} \text { bs })\end{array}$ & Soil Description & Contents \\
\hline X & $170-176$ & Dark grayish brown (10YR 4/2) clay, plastic, abrupt boundary & Sterile \\
XI & $176+$ & $\begin{array}{c}\text { Light gray to light brownish gray (10YR 6/2-7/2) sand and } \\
\text { gravel, friable, non-sticky, non-plastic, boundary not observed }\end{array}$ & Sterile \\
\hline
\end{tabular}

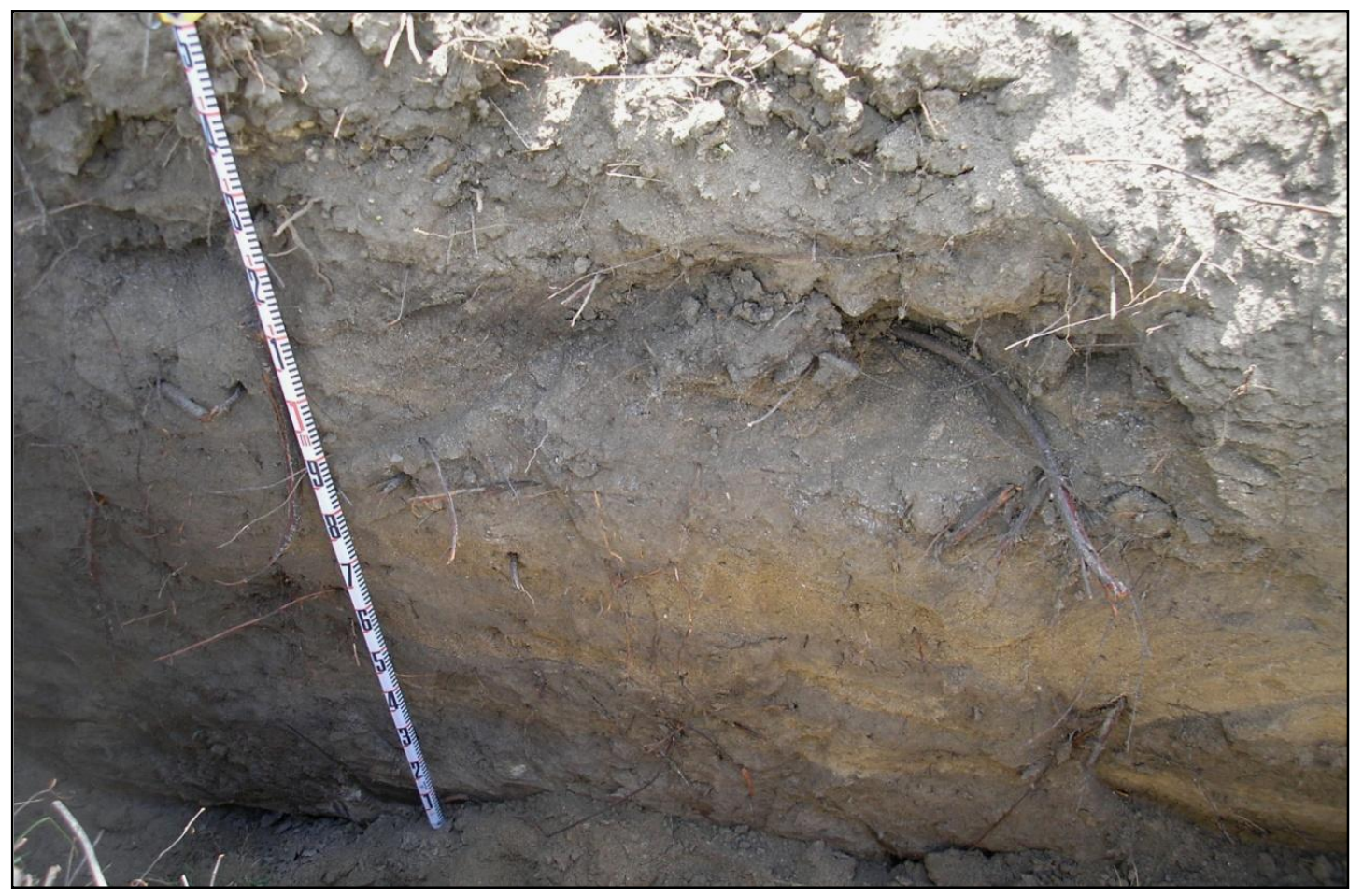

Figure 7. Trench 3 north wall profile.

\section{Trench 5}

Trench 5 was also excavated in the northwestern quadrant, east of Trench 4 . It was $7 \mathrm{~m}$ in length and reached a maximum depth of $175 \mathrm{~cm}$ bs. This trench revealed a sequence of alluvial deposits resulting from flood episodes. Two clear fining upward sequences were apparent in Horizons VI and VII (Table 6, Figure 9). No indication of a buried soil or other stable surface was apparent, and no cultural materials were identified.

\section{Trench 6}

Trench 6 was excavated in the northwestern quadrant of the APE. This trench was $5 \mathrm{~m}$ long and reached a maximum depth of $195 \mathrm{~cm}$ bs. In general, the sediments observed in this trench consisted entirely of overbank deposits with a layer of introduced gravely fill at the surface (Table 7, Figure 10). No buried soil horizons were observed, and no cultural materials were identified. 
Table 5

Backhoe Trench 4 North Wall Profile

\begin{tabular}{|c|c|c|c|}
\hline Horizon & $\begin{array}{r}\text { Depth } \\
(\mathrm{cm} \mathrm{bs})\end{array}$ & Soil Description & Contents \\
\hline I & $0-30$ & $\begin{array}{l}\text { Brown (10YR 4/3) fill with loose gravels, common roots, clear } \\
\text { abrupt boundary }\end{array}$ & Sterile \\
\hline II & $30-46$ & $\begin{array}{l}\text { Brown to dark yellowish brown (10YR 4/3-4/4) fill with thick } \\
\text { gravels, common fine, clear smooth boundary }\end{array}$ & Sterile \\
\hline III & $46-125$ & $\begin{array}{l}\text { Brown (10YR 4/3) silty loam, no structure, non-plastic, few roots, } \\
\text { increase in } \mathrm{CaCO}_{3} \text { near } 85 \mathrm{~cm} \text {, clear smooth boundary }\end{array}$ & Sterile \\
\hline IV & $125-145$ & $\begin{array}{l}\text { Brown (10YR 4/3) gravel lens, heavy } \mathrm{CaCO}_{3} \text { filaments, } 1-5-\mathrm{cm} \\
\text { cobbles, friable, no structure, a clear distinct boundary }\end{array}$ & Sterile \\
\hline V & $145-167$ & $\begin{array}{l}\text { Brown (10YR 4/3-4/4) silty clay loam, sticky, plastic, no roots, and } \\
\text { a clear smooth boundary }\end{array}$ & Sterile \\
\hline VI & $167+$ & $\begin{array}{l}\text { Gravel layer on top of bedrock, did not reach boundary, scraped } \\
\text { with backhoe teeth }\end{array}$ & Sterile \\
\hline
\end{tabular}

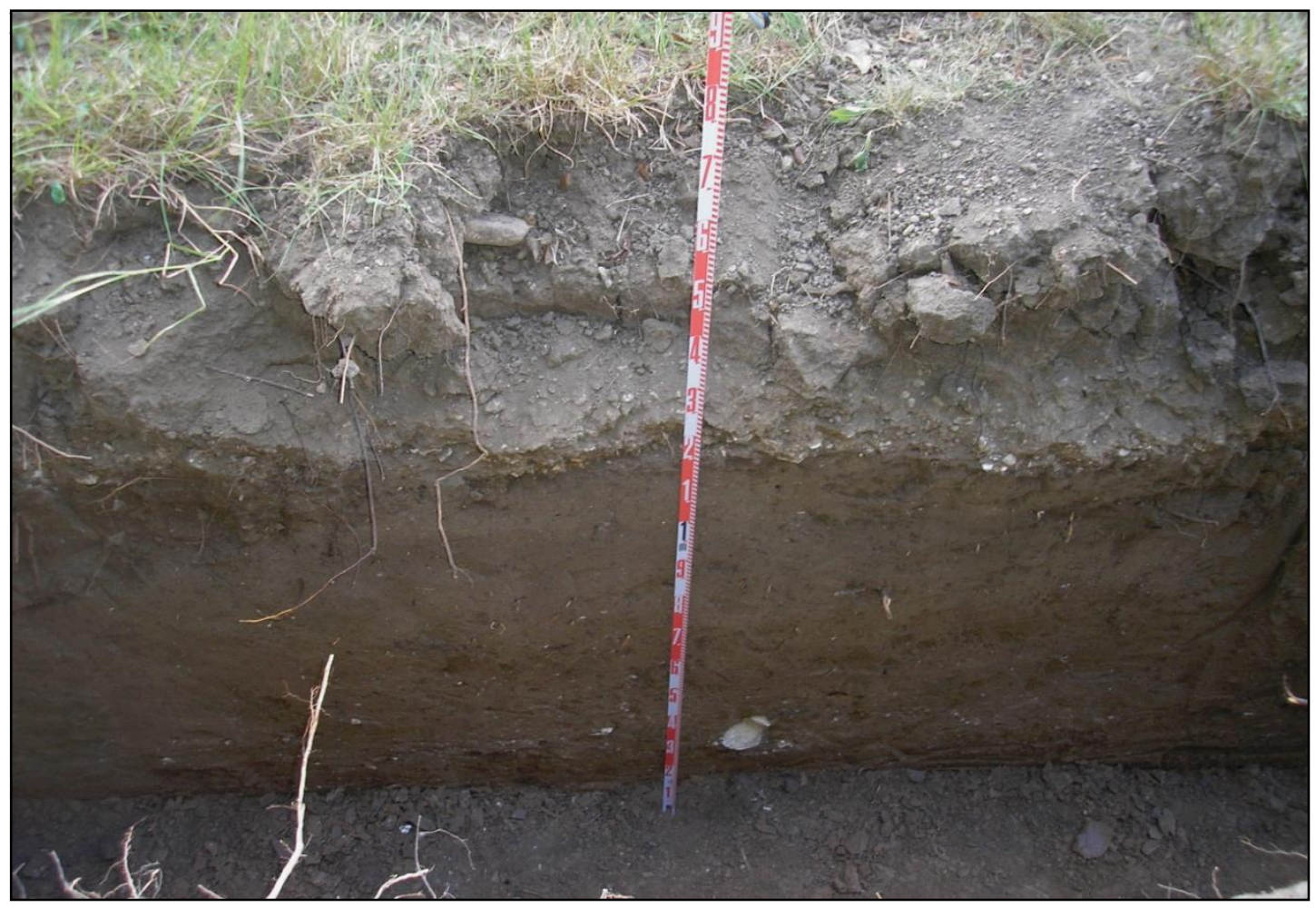

Figure 8. Trench 4 north wall profile. 
Table 6

Backhoe Trench 5 North Wall Profile

\begin{tabular}{|c|c|c|c|}
\hline Horizon & $\begin{array}{r}\text { Depth } \\
(\mathrm{cm} \mathrm{bs})\end{array}$ & \multicolumn{2}{|l|}{ Soil Description } \\
\hline I & $0-30$ & $\begin{array}{l}\text { Dark grayish brown (10YR } 4 / 2-4 / 3) \text { mixed fill including gravel } \\
\text { and clay clasts, common roots, clear abrupt boundary }\end{array}$ & Sterile \\
\hline II & $30-42$ & $\begin{array}{l}\text { Dark grayish brown (10YR 4/2-4/3) fill, silty with laminated } \\
\text { runoff deposits, clear smooth boundary }\end{array}$ & Sterile \\
\hline III & $42-50$ & $\begin{array}{l}\text { Yellowish brown (10YR 5/4) silty loam, no structure, non-plastic, } \\
\text { few roots, and a clear smooth boundary }\end{array}$ & Sterile \\
\hline IV & $50-62$ & Brown (10YR 4/3) gravel lens, abrupt boundary & Sterile \\
\hline $\mathrm{V}$ & $62-95$ & $\begin{array}{l}\text { Brown (10YR 4/3) silty loam, compact, abundant } \mathrm{CaCO}_{3} \text {, friable, } \\
\text { non-sticky, non-plastic, no roots, and a clear smooth boundary }\end{array}$ & Sterile \\
\hline VI & $95-115$ & $\begin{array}{l}\text { Brown (10YR 5/3) coarse sand, fining upward through horizon, } \\
\text { friable, no structure, clear smooth boundary }\end{array}$ & Sterile \\
\hline VII & $115-122$ & $\begin{array}{l}\text { Brown (10YR 5/3) coarse sand, fining upward through horizon, } \\
\text { friable, no structure, clear smooth boundary }\end{array}$ & Sterile \\
\hline VIII & $122-145$ & $\begin{array}{l}\text { Brown (10YR 4/3) sandy silt, no structure, some } \mathrm{CaCO}_{3} \text {, abrupt } \\
\text { boundary }\end{array}$ & Sterile \\
\hline IX & $145-160$ & Brown (10YR 5/3) gravel lens with sand, clear abrupt boundary & Sterile \\
\hline $\mathrm{X}$ & $160-175+$ & $\begin{array}{l}\text { Brown (10YR 4/3) silty sand, non-sticky, non-plastic, boundary } \\
\text { not observed }\end{array}$ & Sterile \\
\hline
\end{tabular}

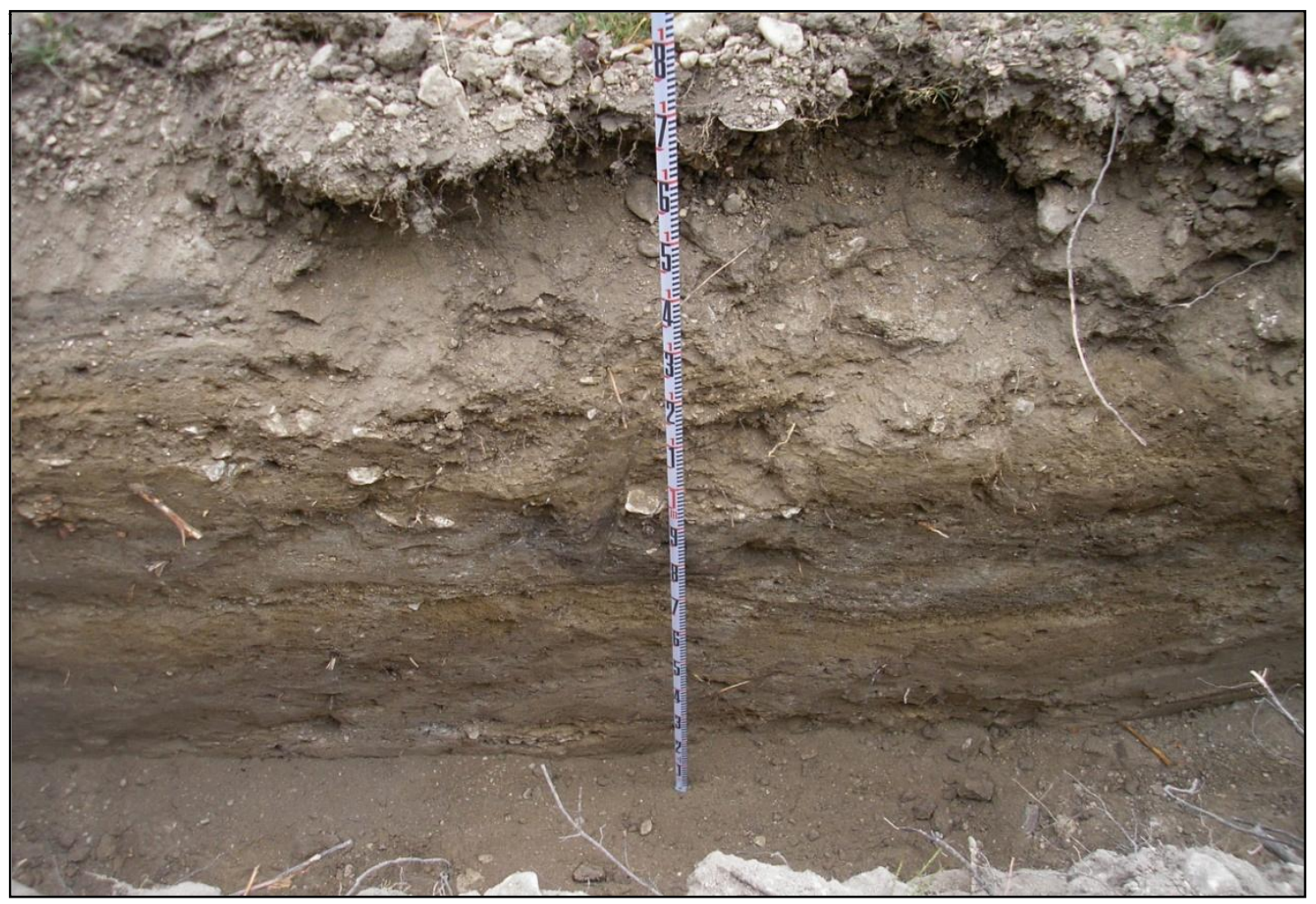

Figure 9. Trench 5 north wall profile. 
Table 7

Backhoe Trench 6 North Wall Profile

\begin{tabular}{|c|c|c|c|}
\hline Horizon & $\begin{array}{r}\text { Depth } \\
(\mathrm{cm} \mathrm{bs})\end{array}$ & Soil Description & Contents \\
\hline I & $0-38$ & $\begin{array}{l}\text { Brown (10YR 4/3) mixed fill including gravel and clay clasts, } \\
\text { common roots, clear abrupt boundary }\end{array}$ & Sterile \\
\hline II & $38-57$ & Brown (10YR 5/3) sand, common fine roots, clear smooth boundary & Sterile \\
\hline III & $57-72$ & $\begin{array}{l}\text { Dark grayish brown (10YR 4/2) silty loam, weak structure, non- } \\
\text { plastic, few roots, clear smooth boundary }\end{array}$ & Sterile \\
\hline IV & $72-85$ & $\begin{array}{l}\text { Brown (10YR 5/3) sand, fining upward, friable, non-plastic, few roots, } \\
\text { no structure, clear smooth boundary }\end{array}$ & Sterile \\
\hline $\mathrm{V}$ & $85-100$ & $\begin{array}{l}\text { Dark grayish brown (10YR 4/2) silty loam, weak structure, non- } \\
\text { plastic, few roots, clear smooth boundary }\end{array}$ & Sterile \\
\hline VI & $100-125$ & $\begin{array}{l}\text { Brown (10YR 5/3) sand, fining upward, friable, non-plastic, no } \\
\text { structure, clear smooth boundary }\end{array}$ & Sterile \\
\hline VII & $125-155$ & $\begin{array}{l}\text { Dark grayish brown }(10 \mathrm{YR} 4 / 2) \text { silty loam, weak structure, non- } \\
\text { plastic, some } \mathrm{CaCO}_{3} \text {, clear smooth boundary }\end{array}$ & Sterile \\
\hline VIII & $155-165$ & $\begin{array}{l}\text { Brown (10YR 5/3) sand, fining upward, friable, non-plastic, no } \\
\text { structure, clear smooth boundary }\end{array}$ & Sterile \\
\hline IX & $165-195$ & $\begin{array}{l}\text { Dark yellowish brown (10YR 4/4-4/6) gravels, coarse sand, pea } \\
\text { gravel, loose, friable, charcoal flecking, boundary not observed }\end{array}$ & Sterile \\
\hline
\end{tabular}

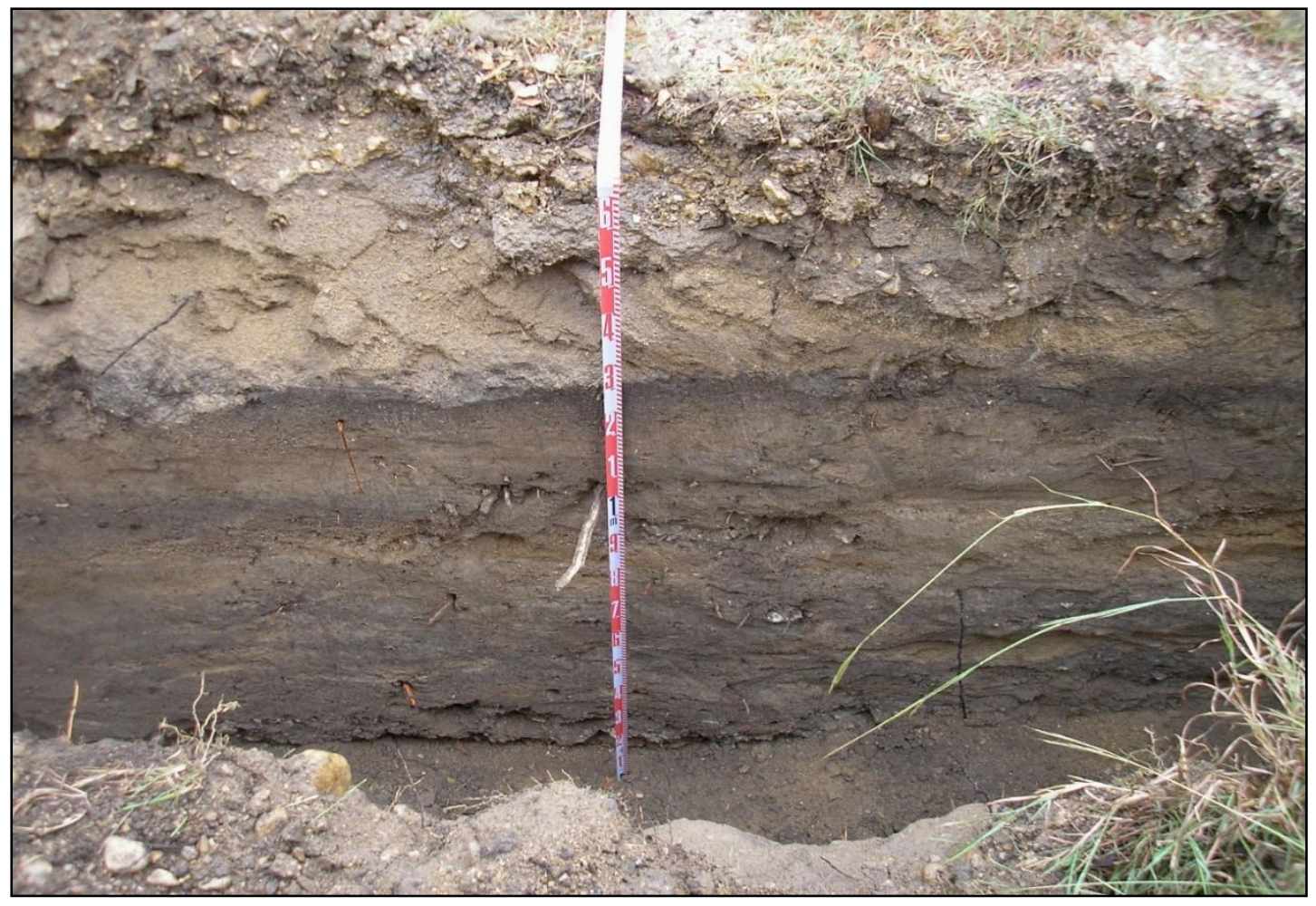

Figure 10. Trench 6 north wall profile. 


\section{Trench 7}

Trench 7 was excavated in the southeastern quadrant, farthest from the creek. This trench had a total length of $7 \mathrm{~m}$ and reached a maximum depth of $195 \mathrm{~cm}$ bs. Bedrock was never encountered, and no cultural materials were observed (Table 8, Figure 11).

Table 8

Backhoe Trench 7 North Wall Profile

\begin{tabular}{|c|c|c|c|}
\hline Horizon & $\begin{array}{r}\text { Depth } \\
(\mathrm{cm} \mathrm{bs})\end{array}$ & Soil Description & Contents \\
\hline I & $0-20$ & $\begin{array}{l}\text { Yellowish brown (10YR 5/4) fill with mixed gravels, laminated } \\
\text { clays and sands, common roots, clear abrupt boundary }\end{array}$ & Sterile \\
\hline II & $20-46$ & $\begin{array}{l}\text { Very dark grayish brown (10YR } 3 / 2) \text { silty clay loam soil, abundant } \\
\text { roots, some loading apparent, gradual boundary }\end{array}$ & Sterile \\
\hline III & $46-90$ & $\begin{array}{l}\text { Dark brown (10YR 3/3) grades to dark yellowish brown (10YR 4/4) } \\
\text { upper is a silty loam that grades down into sandy silty loam, } \\
\text { granular, non-plastic, roots, clear smooth boundary }\end{array}$ & Sterile \\
\hline IV & $90-140$ & $\begin{array}{l}\text { Dark grayish brown (10YR 4/2) silty loam, compact, very weak } \\
\text { structure, abundant } \mathrm{CaCO}_{3} \text { filaments, diffuse boundary }\end{array}$ & Sterile \\
\hline V & $140-195$ & $\begin{array}{l}\text { Brown }(10 \text { YR } 5 / 3-4 / 3) \text { sandy silty loam, granular, non-sticky, } \\
\text { friable, no roots, did not observe boundary }\end{array}$ & Sterile \\
\hline
\end{tabular}

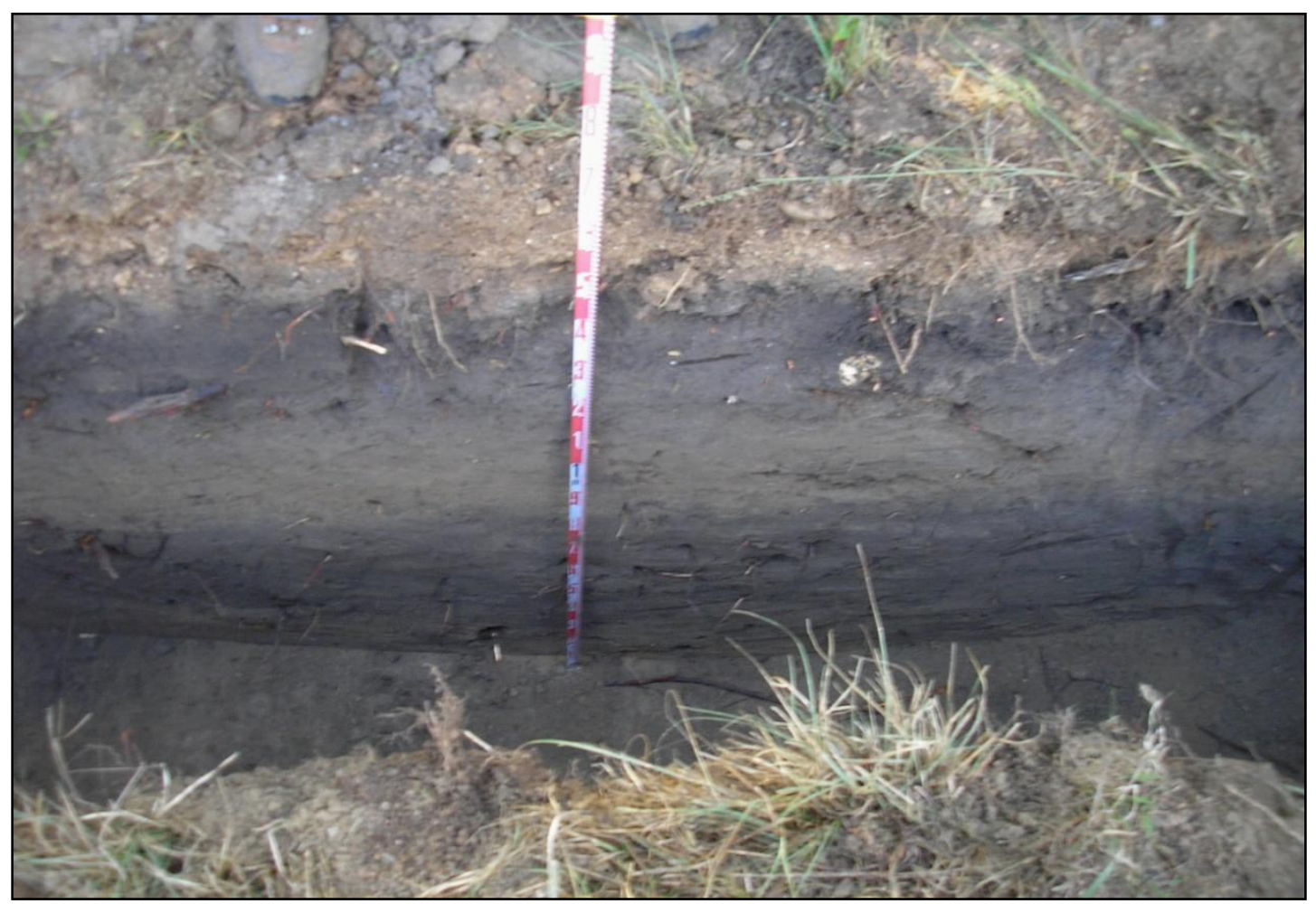

Figure 11. Trench 7 north wall profile. 


\section{Trench 8}

Trench 8 was excavated in the southeastern quadrant of the APE. This trench reached a total length of $7 \mathrm{~m}$ and a maximum depth of $190 \mathrm{~cm}$ bs. Bedrock was not encountered. A concentration of charcoal and possible burned rock was observed at approximately $185 \mathrm{~cm}$ bs (Table 9, Figure 12). To determine if these materials were cultural in origin, one 1-x-1-m test unit (Test Unit 1) was placed adjacent to the trench.

\begin{tabular}{|c|c|c|c|}
\hline \multirow[b]{2}{*}{ Horizon } & & $\begin{array}{c}\text { Table } 9 \\
\text { Backhoe Trench } 8 \text { North Wall Profile }\end{array}$ & \multirow[b]{2}{*}{ Contents } \\
\hline & $(\mathrm{cm} \mathrm{bs})$ & Soil Description & \\
\hline I & $0-42$ & $\begin{array}{l}\text { Brown (10YR } 4 / 3) \text { loaded fill with mixed gravels and clay clasts, } \\
\text { clear abrupt boundary }\end{array}$ & Sterile \\
\hline II & $42-55$ & Brown (10YR 5/3) sand, likely fill, discrete boundary & Sterile \\
\hline III & $55-76$ & $\begin{array}{l}\text { Dark brown (10YR 3/3) silty clay, appears to be the A horizon } \\
\text { buried by fill, common roots, some } \mathrm{CaCO}_{3} \text {, diffuse boundary }\end{array}$ & Sterile \\
\hline IV & $76-88$ & $\begin{array}{l}\text { Dark grayish brown (10YR 4/4) sandy silty loam, compact, very } \\
\text { weak structure, roots, } \mathrm{CaCO}_{3} \text { filaments, clear gradual boundary }\end{array}$ & Sterile \\
\hline $\mathrm{V}$ & $88-164$ & $\begin{array}{l}\text { Very dark grayish brown }(10 \mathrm{YR} 3 / 2) \text { silty loam, roots, granular, } \\
\text { non-sticky, abundant } \mathrm{CaCO}_{3} \text { filaments, gradual smooth boundary }\end{array}$ & Sterile \\
\hline VI & $164+$ & $\begin{array}{l}\text { Dark grayish brown (10YR 4/2) sandy silt, scattered charcoal } \\
\text { flecks, boundary not observed, gravels at base }\end{array}$ & $\begin{array}{l}\text { Smoothed } \\
\text { flake }\end{array}$ \\
\hline
\end{tabular}

\section{Trench 9}

Trench 9 was excavated in the southeastern quadrant nearest the creek. This trench reached a maximum depth of $175 \mathrm{~cm}$ bs and a total length of $5.5 \mathrm{~m}$. The upper $80 \mathrm{~cm}$ of this trench consisted of fill. Near the bottom of the fill deposits, large cut limestone blocks and concrete slabs retaining rebar were exposed (Table 10, Figure 13). It is likely that this material is associated with previous bridge replacements. Below this fill gravel, channel deposits were encountered.

\section{Trench 10}

Trench 10 was excavated in the northeastern quadrant of the APE at site 41BT427. This trench was excavated to a maximum depth of $220 \mathrm{~cm}$ bs and was $7.5 \mathrm{~m}$ in length. A cluster of three burned rocks was exposed in the north wall at approximately $80-85 \mathrm{~cm}$ bs (Table 11; Figure 14). One additional burned rock was located a meter east of the cluster at $85-90 \mathrm{~cm}$ bs. Charcoal flecks were scattered between 70-210 cm bs. No burned rock was apparent below $1 \mathrm{~m}$, and there was no evidence of the lower component identified when the site was originally recorded. Test Units 4 and 5 were excavated adjacent to Trench 10. 


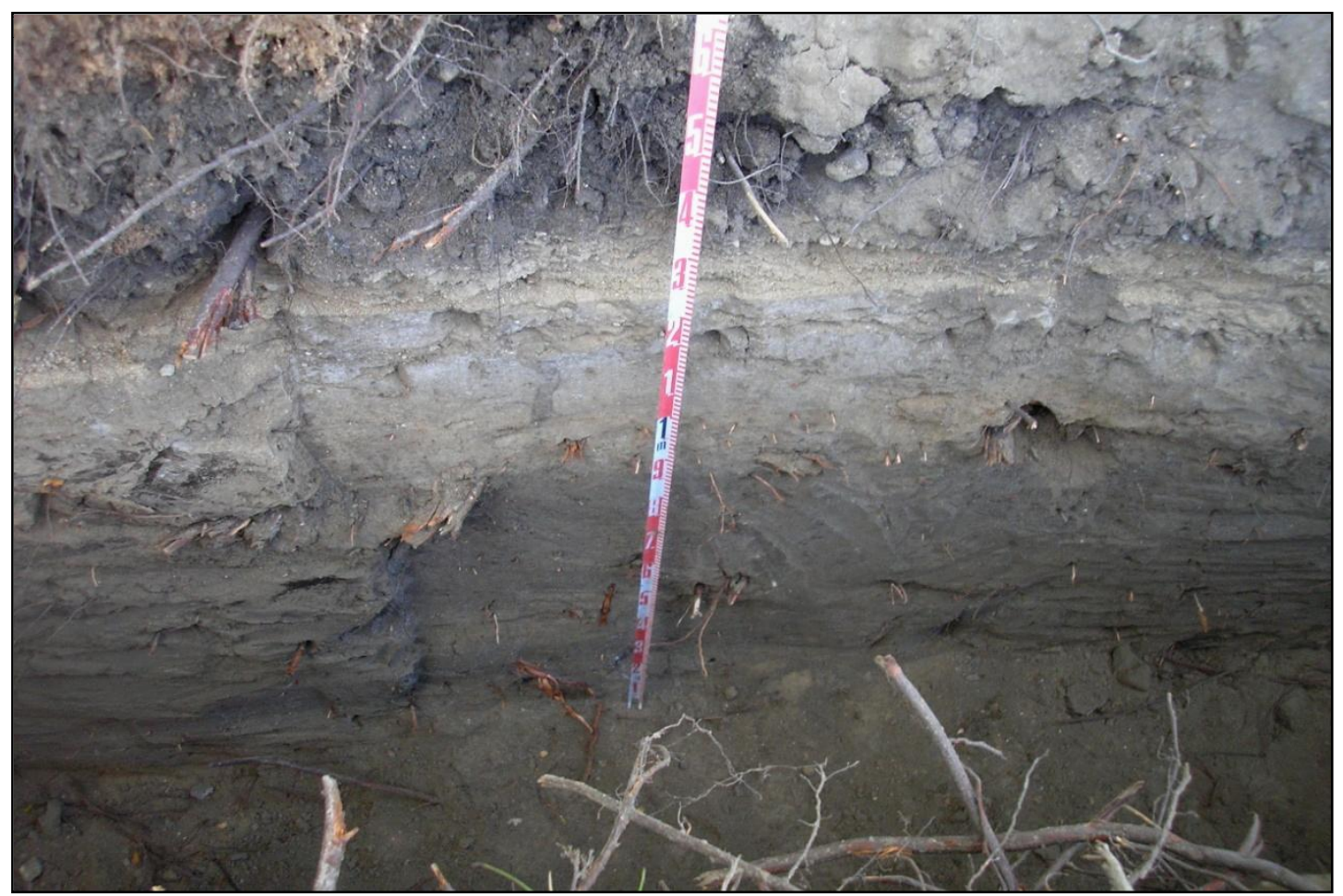

Figure 12. Trench 8 north wall profile.

Table 10

Backhoe Trench 9 North Wall Profile

\begin{tabular}{crll} 
Horizon & $\begin{array}{r}\text { Depth } \\
(\mathrm{cm} \mathrm{bs})\end{array}$ & Soil Description & Contents \\
\hline I & $0-80$ & $\begin{array}{c}\text { Mixed gravel fill containing limestone blocks and concrete slabs } \\
\text { with rebar, clear abrupt boundary }\end{array}$ & Sterile \\
II & $80-175$ & Gravel and coarse sand channel deposits & Sterile \\
\hline
\end{tabular}

\section{Trench 11}

Trench 11 was excavated in the northeastern quadrant of the APE, at site 41BT427. This trench was excavated to a maximum depth of $220 \mathrm{~cm}$ bs and was $7.5 \mathrm{~m}$ in length. Charcoal was observed throughout the profile between 70 and $210 \mathrm{~cm}$ bs. One bivalve shell and a burned rock located in Horizon III, at $90 \mathrm{~cm}$ bs in the north wall, were the impetus for the placement of Test Unit 2 along this trench (Table 12, Figure 15). A safety bench was excavated on the northern side of the trench and overburden was removed to approximately $70 \mathrm{~cm} \mathrm{bs}$. 


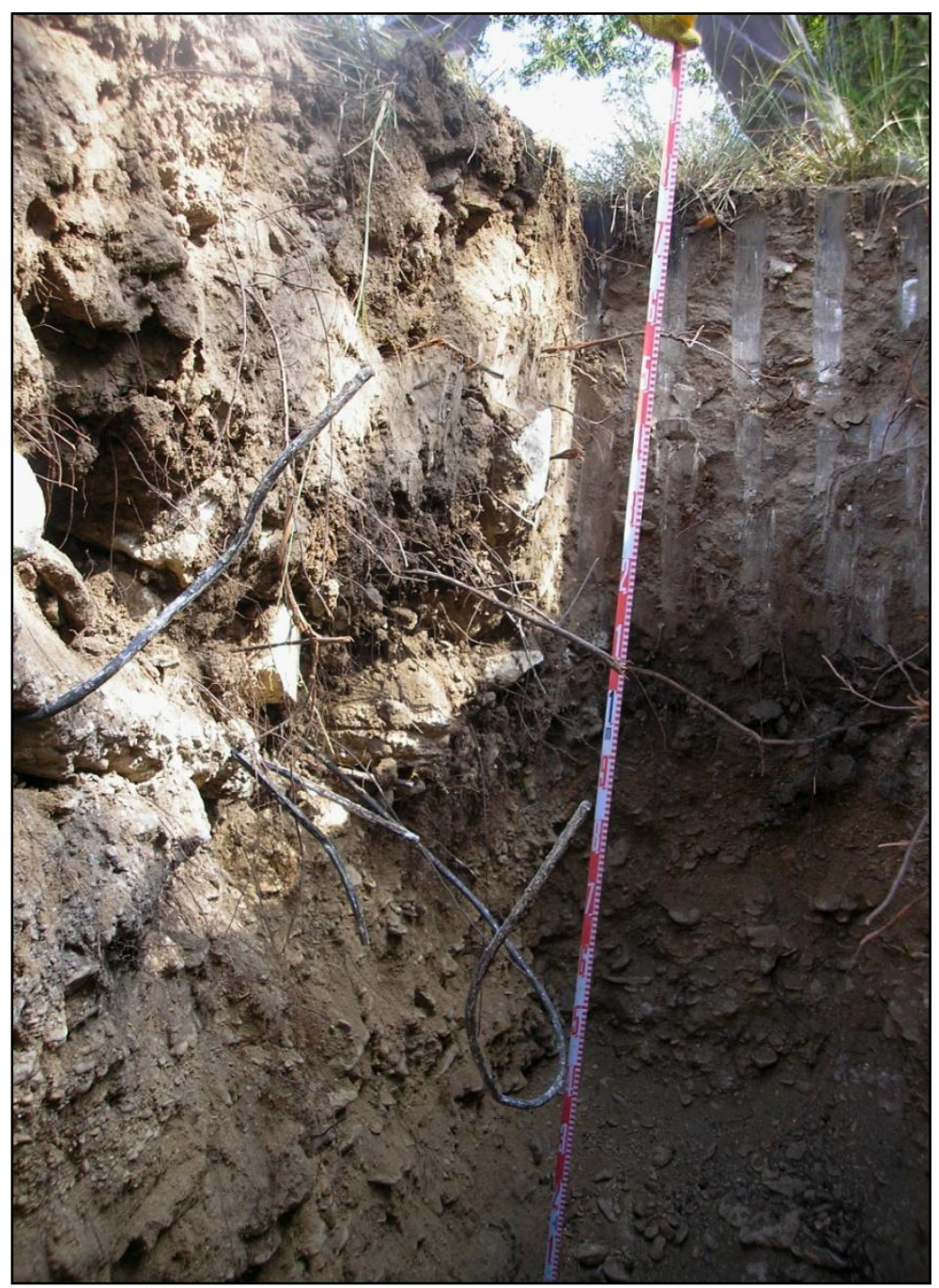

Figure 13. Trench 9 north wall profile.

\section{Trench 12}

Trench 12 was excavated in the northeastern quadrant of the APE at site 41BT427. This trench was excavated to a maximum depth of $217 \mathrm{~cm}$ bs and a total length of $7 \mathrm{~m}$. No cultural material or burned rock was observed in either profile of Trench 12, though charcoal was dispersed throughout much of the trench below $75 \mathrm{~cm}$ (Table 13, Figure 16). Nevertheless, Test Unit 3 was placed adjacent to Trench 12.

\section{Trench 13}

Trench 13 was excavated in the northeastern quadrant of the APE at site 41BT427. This trench reached a maximum depth of $175 \mathrm{~cm}$ bs and a total length of $7.5 \mathrm{~m}$. One large tabular piece of limestone was removed from this trench during mechanical excavation but was not observed until it was dumped into the backdirt pile (Figure 17). This limestone slab might possibly be ground 
Table 11

Backhoe Trench 10 North Wall Profile

\begin{tabular}{|c|c|c|c|}
\hline Horizon & $\begin{array}{r}\text { Depth } \\
(\mathrm{cm} \mathrm{bs})\end{array}$ & Soil Description & Contents \\
\hline I & $0-27$ & $\begin{array}{l}\text { Black (10YR } 2 / 1) \text { silty clay with abundant vegetation and } \\
\text { common roots, diffuse boundary }\end{array}$ & Sterile \\
\hline II & $27-49$ & $\begin{array}{l}\text { Very dark grayish brown (10YR } 3 / 2) \text { silty clay, common fine } \\
\text { roots, gradual diffuse boundary }\end{array}$ & Sterile \\
\hline III & $49-62$ & $\begin{array}{l}\text { Dark grayish brown (10YR 4/2) sandy silty clay, weak } \\
\text { structure, non-plastic, few roots, and a clear smooth } \\
\text { boundary }\end{array}$ & Sterile \\
\hline IV & $62-111$ & $\begin{array}{l}\text { Very dark grayish brown (10YR 3/2) granular silty loam, } \\
\text { compact, non-plastic, few roots, charcoal flecking, weak } \\
\text { structure, with a diffuse boundary }\end{array}$ & $\begin{array}{l}\text { Burned rock, } \\
\text { bone }\end{array}$ \\
\hline V & $111-118$ & $\begin{array}{l}\text { Dark grayish brown (10YR 4/2) silty clay, charcoal flecking, } \\
\text { sticky, plastic, no roots, common } \mathrm{CaCO}_{3} \text { filaments, and a } \\
\text { clear smooth boundary }\end{array}$ & Sterile \\
\hline VI & $118-163$ & $\begin{array}{l}\text { Very dark grayish brown (10YR 3/2) silty loam, weak } \\
\text { structure, charcoal flecking, } \mathrm{CaCO}_{3} \text { filaments, clear } \\
\text { discrete boundary }\end{array}$ & Sterile \\
\hline VII & $163-220$ & $\begin{array}{l}\text { Brown (10YR 4/3) silty sand, charcoal flecking, non-sticky, } \\
\text { non-plastic, grading down to coarser sands and gravels }\end{array}$ & Sterile \\
\hline
\end{tabular}

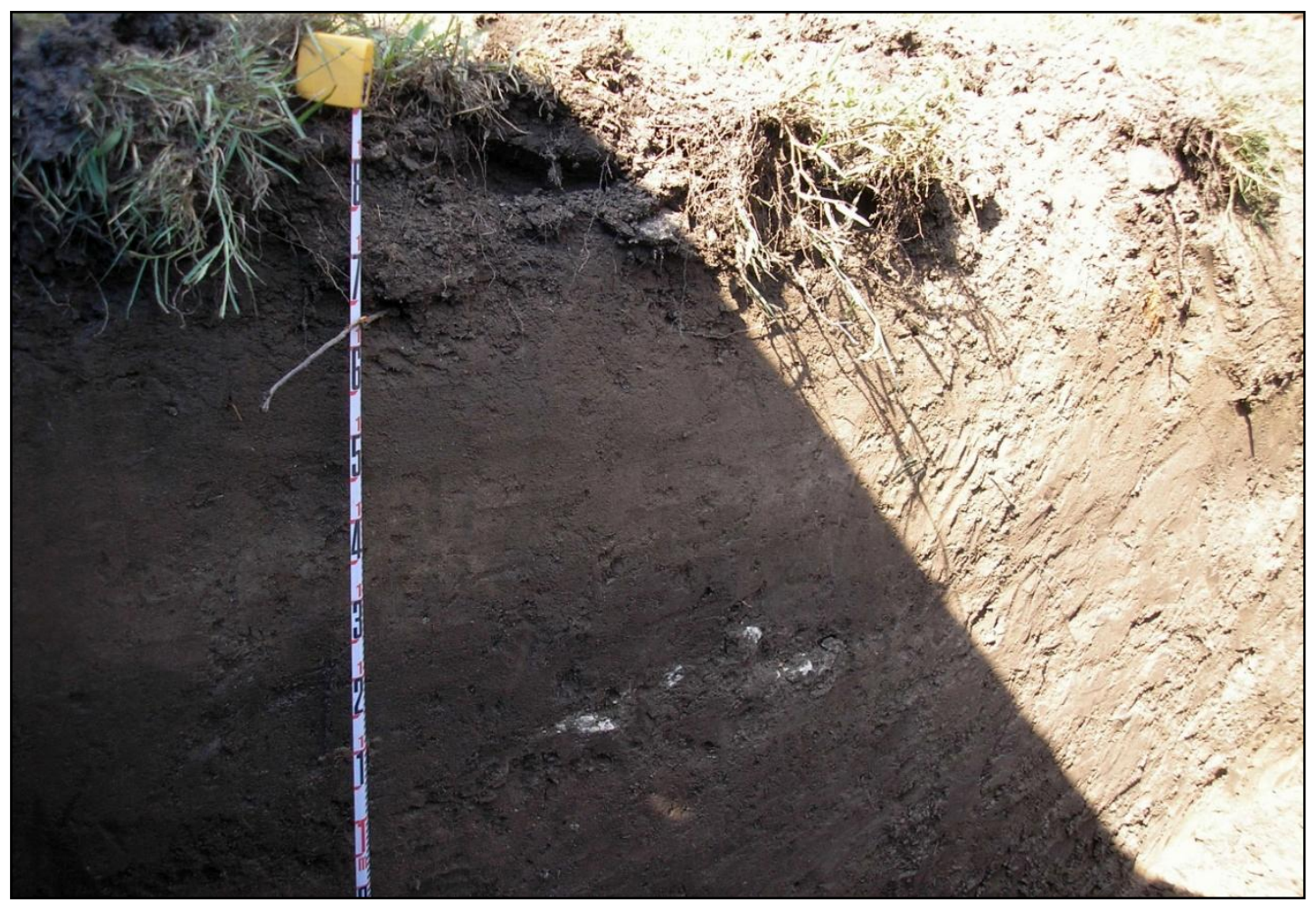

Figure 14. Burned rock cluster in Trench 10 north wall profile. 
Table 12

Backhoe Trench 11 North Wall Profile

\begin{tabular}{|c|c|c|c|}
\hline Horizon & $\begin{array}{r}\text { Depth } \\
(\mathrm{cm} \mathrm{bs})\end{array}$ & Soil Description & Contents \\
\hline I & $0-20$ & $\begin{array}{l}\text { Very dark grayish brown (10YR 3/2) silty clay with some small } \\
\text { pebbles dispersed, somewhat mixed appearance, common roots, } \\
\text { clear abrupt boundary }\end{array}$ & Sterile \\
\hline II & $20-77$ & $\begin{array}{l}\text { Brown (10YR 4/3) sandy silty loam, small charcoal flecks } \\
\text { throughout, common fine roots, non-plastic, clear smooth } \\
\text { boundary }\end{array}$ & Sterile \\
\hline III & 77-99 & $\begin{array}{l}\text { Dark grayish brown (10YR 4/2) sandy silty loam, very few tiny } \\
\text { charcoal flecks, non-plastic, diffuse boundary }\end{array}$ & $\begin{array}{l}\text { Mussel shell, } \\
\text { burned } \\
\text { rock }\end{array}$ \\
\hline IV & 99-105 & $\begin{array}{l}\text { Brown (10YR 4/3) silty sandy loam, friable, non-plastic, few roots, } \\
\text { weak structure, charcoal flecking, clear smooth boundary }\end{array}$ & Sterile \\
\hline V & $105-120$ & $\begin{array}{l}\text { Brown (10YR 4/3) silty loam, non-plastic, no roots, charcoal } \\
\text { flecking, clear smooth boundary }\end{array}$ & Sterile \\
\hline VI & $120-133$ & $\begin{array}{l}\text { Brown }(10 \mathrm{YR} 4 / 3) \text { silty clay with common } \mathrm{CaCO}_{3} \text { filaments and } \\
\text { redox staining, clear boundary }\end{array}$ & Sterile \\
\hline VII & $133-143$ & $\begin{array}{l}\text { Brown (10YR 4/3) silty loam, non-plastic, no roots, charcoal } \\
\text { flecking, clear smooth boundary }\end{array}$ & Sterile \\
\hline VIII & $143-153$ & $\begin{array}{l}\text { Brown (10YR 4/3) silty sandy loam, friable, non-plastic, few roots, } \\
\text { weak structure, charcoal flecking, clear smooth boundary }\end{array}$ & Sterile \\
\hline IX & $153-167$ & $\begin{array}{l}\text { Brown (10YR 4/3) silty loam, non-plastic, no roots, charcoal } \\
\text { flecking, clear smooth boundary }\end{array}$ & Sterile \\
\hline$X$ & $167-175$ & $\begin{array}{l}\text { Brown (10YR 4/3) silty sandy loam, friable, non-plastic, few roots, } \\
\text { weak structure, charcoal flecking, clear smooth boundary }\end{array}$ & Sterile \\
\hline XI & $175-207$ & $\begin{array}{l}\text { Brown (10YR 4/3) sandy silty clay, charcoal flecks, non-sticky, } \\
\text { non-plastic, gradual boundary }\end{array}$ & Sterile \\
\hline XII & $207-228$ & $\begin{array}{l}\text { Yellowish brown (10YR 5/4) sand, weak structure, friable, charcoal } \\
\text { flecking, discrete boundary, lens of darker sediment with } \\
\text { charcoal }\end{array}$ & Sterile \\
\hline XIII & $228+$ & $\begin{array}{l}\text { Dark yellowish brown (10YR 4/4-4/6) gravels, coarse sand, pea } \\
\text { gravel, loose, friable, charcoal flecking, boundary not observed }\end{array}$ & Sterile \\
\hline
\end{tabular}

stone, though no striations were observed upon careful inspection and it was not clearly ground. Two large burned rocks were observed during trench excavation at the eastern end of the trench in the north wall. These rocks were located at $90 \mathrm{~cm}$ bs in Horizon III (Table 14, Figure 18). Four rocks that appeared to be burned were located at $185 \mathrm{~cm}$ bs. Test Units $6-9$ were excavated adjacent to Trench 13. 


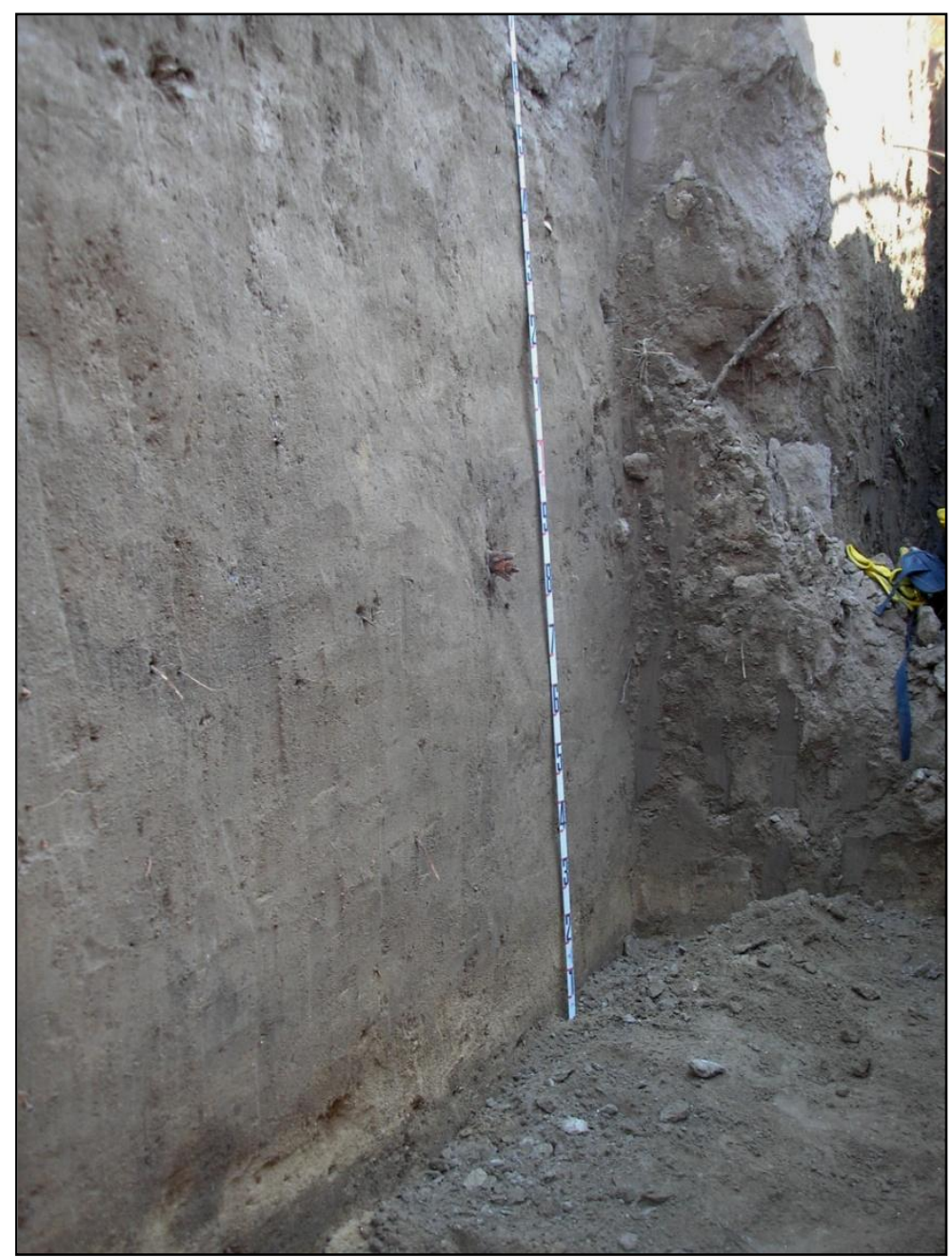

Figure 15. Trench 11 north wall profile.

Table 13

Backhoe Trench 12 North Wall Profile

\begin{tabular}{|c|c|c|c|}
\hline Horizon & $\begin{array}{r}\text { Depth } \\
(\mathrm{cm} \mathrm{bs})\end{array}$ & Soil Description & Contents \\
\hline I & $0-29$ & $\begin{array}{l}\text { Very dark grayish brown (10YR 3/2) silty clay, blocky } \\
\text { structure, common roots, clear abrupt boundary }\end{array}$ & Sterile \\
\hline II & $29-95$ & $\begin{array}{l}\text { Brown }(10 \mathrm{YR} 4 / 3) \text { sandy silty loam, compact, } \mathrm{CaCO}_{3} \text { filaments, } \\
\text { charcoal flecking, gradual boundary }\end{array}$ & Sterile \\
\hline III & $95-150$ & $\begin{array}{l}\text { Brown }(10 \mathrm{YR} 4 / 3) \text { sandy silty loam, granular, non-plastic, } \\
\mathrm{CaCO}_{3} \text { filaments, charcoal flecking, clear smooth boundary }\end{array}$ & Sterile \\
\hline IV & $150-195$ & $\begin{array}{l}\text { Brown (10YR 4/2-4/3) silty loam, compact, very weak structure, } \\
\text { abundant } \mathrm{CaCO}_{3} \text { filaments, charcoal flecking, diffuse } \\
\text { boundary }\end{array}$ & Sterile \\
\hline $\mathrm{V}$ & $195-220+$ & $\begin{array}{l}\text { Brown (10YR 4/3) gravel from pea-size to } 15 \mathrm{~cm} \text { in diameter, } \\
\text { did not observe boundary }\end{array}$ & Sterile \\
\hline
\end{tabular}




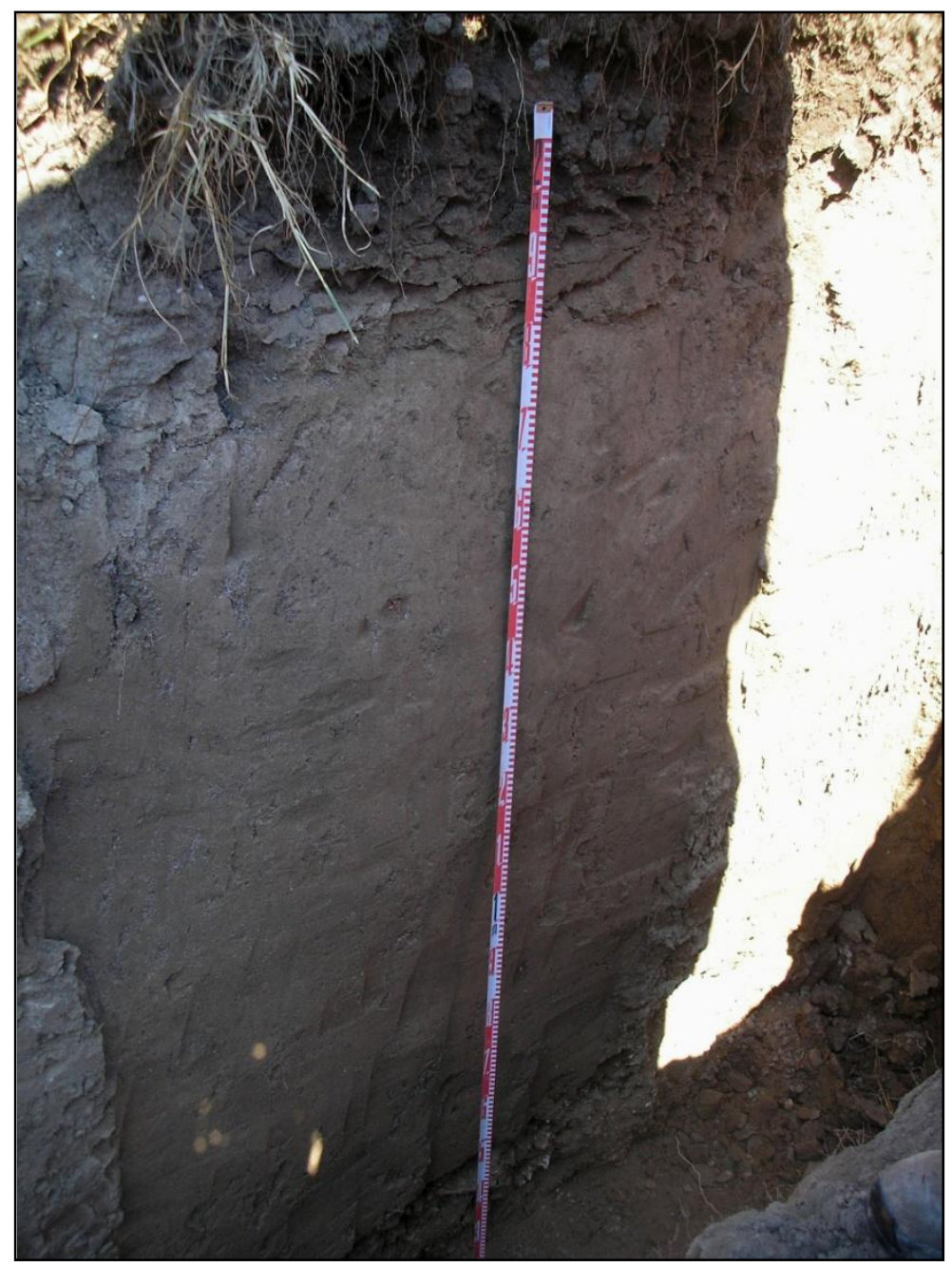

Figure 16. Trench 12 north wall profile.

\section{Test Unit Excavations}

National Register eligibility testing at 41BT427 entailed the excavation of eight 1-x-1-m test units within the boundary of the site (Test Units 2-9) and one test unit outside the known southern site boundary (Test Unit 1). Each test unit was excavated adjacent to one of the four trenches excavated within the site boundaries (see Figure 4). The additional test unit (Test Unit 1) was placed outside the site across FM 963 adjacent to Trench 8 to test what appeared to be a concentration of charcoal and a burned rock in the trench profile. Overall, excavations from the testing yielded 105 chipped stone artifacts including one biface fragment and one projectile point fragment, 59 pieces of bone, and 21 pieces of mussel shell (see Appendix A). As charcoal was observed throughout the profile of each of these units, samples were collected within levels with associated artifacts as well as randomly in levels with low artifact recovery. In addition, $82.2 \mathrm{~g}$ of burned clay or burned earth were collected for inspection in the laboratory for impressions. 


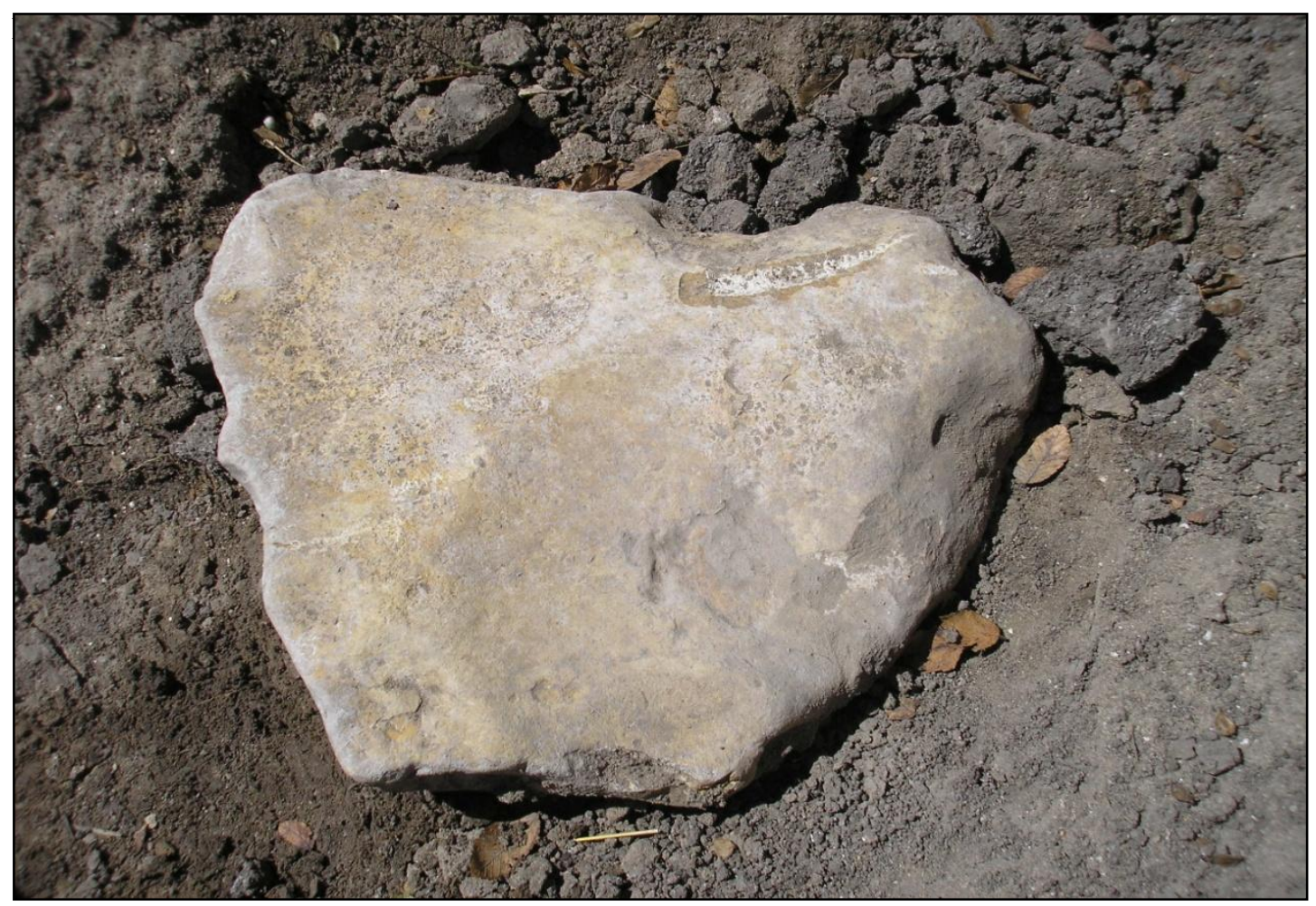

Figure 17. Tabular piece of limestone recovered from Trench 13.

Table 14

Backhoe Trench 13 North Wall Profile

\begin{tabular}{|c|c|c|c|}
\hline Horizon & $\begin{array}{r}\text { Depth } \\
(\mathrm{cm} \mathrm{bs})\end{array}$ & Soil Description & Contents \\
\hline I & $0-27$ & $\begin{array}{l}\text { Very dark grayish brown (10YR 3/2) silty clay loam, common } \\
\text { roots, clear abrupt boundary }\end{array}$ & Sterile \\
\hline II & $27-49$ & $\begin{array}{l}\text { Very dark grayish brown (10YR 3/2) sandy silty clay, } \mathrm{CaCO}_{3} \\
\text { filaments, clear smooth boundary }\end{array}$ & Sterile \\
\hline III & $49-93$ & $\begin{array}{l}\text { Very dark gray (10YR 3/1) silty clay, thick common } \mathrm{CaCO}_{3} \\
\text { filaments, weak structure, plastic, few roots, diffuse boundary }\end{array}$ & Burned rock \\
\hline IV & $93-120$ & $\begin{array}{l}\text { Very dark grayish brown (10YR 3/2) silty loam, abundant } \\
\text { charcoal flecking, weak structure, } \mathrm{CaCO}_{3} \text { filaments, clear } \\
\text { smooth boundary }\end{array}$ & Sterile \\
\hline V & $120-150$ & $\begin{array}{l}\text { Brown (10YR 4/2-4/3) sandy silty loam, } \mathrm{CaCO}_{3} \text {, non-sticky, non- } \\
\text { plastic, no roots, discrete smooth boundary }\end{array}$ & Sterile \\
\hline VI & $150-175$ & $\begin{array}{l}\text { Dark grayish brown (10YR 4/2) silt, charcoal flecking, weak } \\
\text { structure, diffuse boundary }\end{array}$ & Sterile \\
\hline VII & $175-195$ & $\begin{array}{l}\text { Dark gray to dark grayish brown (10YR } 4 / 1-4 / 2) \text { clayey silt, } \\
\text { plastic, moderately sticky, discrete boundary }\end{array}$ & $\begin{array}{l}\text { Possible } \\
\text { burned rock }\end{array}$ \\
\hline VIII & $195-215$ & $\begin{array}{l}\text { Brown (10YR } 5 / 3 \text { ) clay, sand, and gravel. Gravels range from } \\
\text { pea-size to } 10 \mathrm{~cm} \text { in diameter, very wet, did not observe } \\
\text { boundary }\end{array}$ & Sterile \\
\hline
\end{tabular}




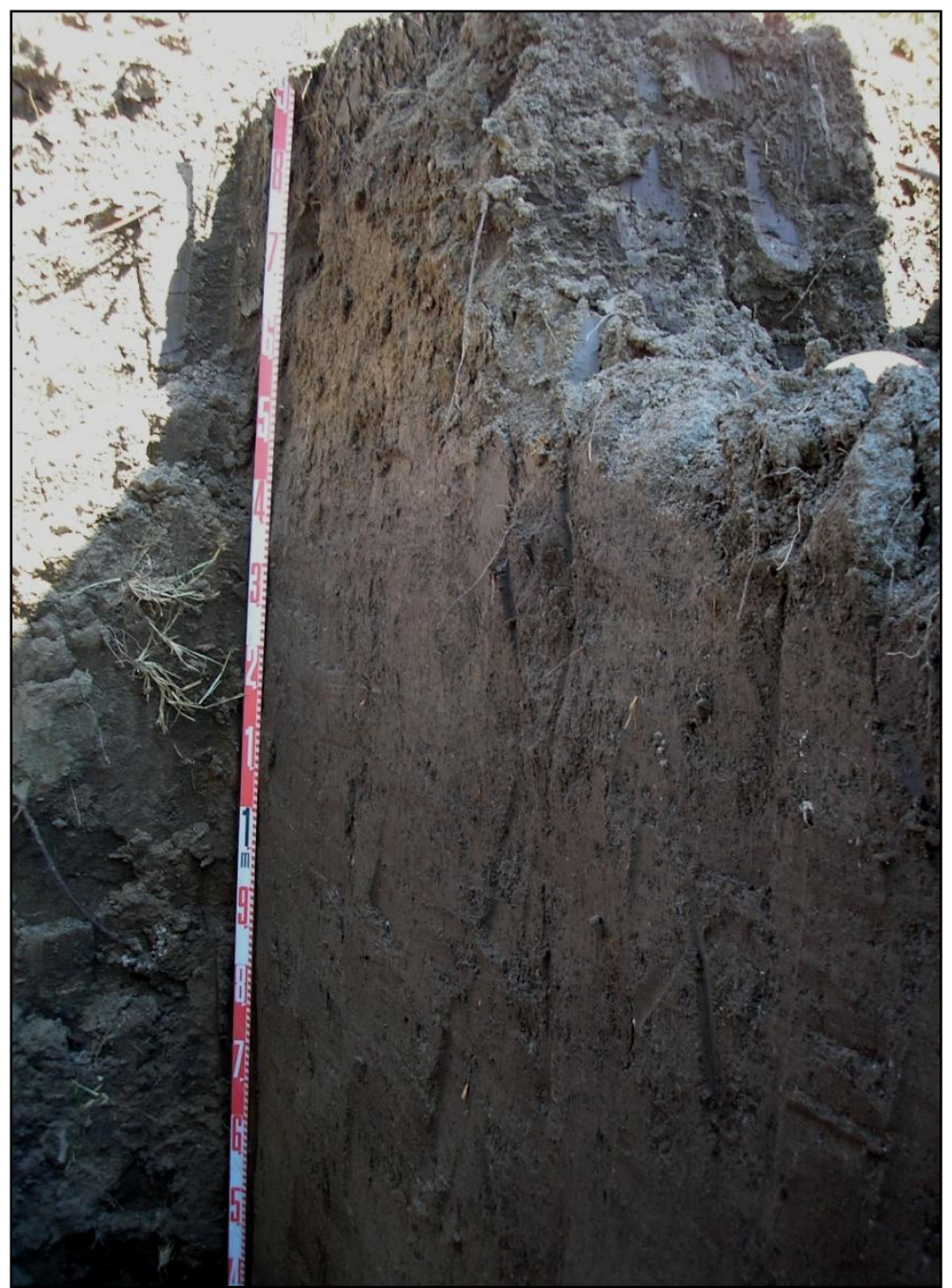

Figure 18. Trench 13 north wall profile.

\section{Test Unit 1 (98.83-98.38 m Elevation [174-219 cm bs])}

Test Unit 1 was excavated in the southeast quadrant adjacent to Trench 8, outside the boundaries of site 41BT427. This test unit and trench served primarily to prospect for cultural materials on the opposite side of the road from the originally defined boundary for site 41BT427. Test Unit 1 was excavated to test a charcoal concentration observed at approximately $185 \mathrm{~cm}$ bs (elevation $98.72 \mathrm{~m}$ ), the recorded depth for the lower component originally recorded at site 41BT427. To determine if this material was cultural in origin, 1-x-1-m Test Unit 1 was placed adjacent to the trench. Several small fragments of possibly burned rock and one smoothed chipped stone flake were encountered at $200 \mathrm{~cm}$ bs (elevation $98.57 \mathrm{~m}$ ) in a gravel lens (Table 15). It is unlikely that this material represents in situ cultural activity. 
Table 15

All Artifact Types Identified from All Proveniences at 41BT427

\begin{tabular}{|c|c|c|c|c|c|c|c|c|c|c|c|}
\hline $\begin{array}{l}\text { Test } \\
\text { Unit }\end{array}$ & Level & $\begin{array}{c}\text { Depth } \\
(\mathrm{cm} \mathrm{bs})\end{array}$ & Elevation $(\mathrm{m})$ & $\begin{array}{l}\text { Proj. } \\
\text { Point }\end{array}$ & Biface & $\begin{array}{l}\text { Chipped } \\
\text { Stone } \\
\text { Debitage }\end{array}$ & Shell & $\begin{array}{l}\text { Charcoal } \\
\text { Sample/g }\end{array}$ & $\begin{array}{c}\text { Burned } \\
\text { Clay }(\mathrm{g})\end{array}$ & Bone & $\begin{array}{c}\text { Burned } \\
\text { Rock/kg }\end{array}$ \\
\hline 1 & 1 & $174-184$ & $98.83-98.73$ & - & - & - & - & $100 / 31.1 \mathrm{~g}$ & - & - & 0 \\
\hline 1 & 4 & 204-219 & $98.53-98.38$ & - & - & 1 & - & - & - & - & - \\
\hline 2 & 4 & $90-100$ & $99.37-99.27$ & - & - & - & - & $\begin{array}{c}1 \\
5 / 2.6 \mathrm{~g}\end{array}$ & - & - & $\begin{array}{l}.1 \\
0\end{array}$ \\
\hline 2 & 5 & $100-110$ & $99.27-99.17$ & - & - & 1 & - & $\begin{array}{c}1 \\
7 / 3.4 \mathrm{~g}\end{array}$ & - & - & $\begin{array}{c}.01 \\
0\end{array}$ \\
\hline 2 & 7 & $120-130$ & 99.07-98.97 & - & - & - & - & - & & & $\begin{array}{l}.3 \\
0\end{array}$ \\
\hline 2 & 16 & $210-220$ & 98.17-98.07 & - & - & - & - & - & - & - & $\begin{array}{l}.2 \\
0\end{array}$ \\
\hline 3 & 1 & $55-65$ & $99.55-99.45$ & - & - & $\begin{array}{l}1 \\
0\end{array}$ & - & - & - & - & $\begin{array}{c}.1 \\
4 / 10.5\end{array}$ \\
\hline 3 & 2 & $65-75$ & $99.45-99.35$ & - & - & 2 & - & - & - & - & $\begin{array}{c}.1 \\
7 / 34.1\end{array}$ \\
\hline 3 & 3 & $75-85$ & $99.35-99.25$ & - & - & - & - & $\begin{array}{c}1 \\
20 / 1.9 \mathrm{~g}\end{array}$ & - & - & $\begin{array}{c}.1 \\
4 / 17.9\end{array}$ \\
\hline 3 & 4 & $85-95$ & $99.25-99.15$ & - & - & - & - & $\begin{array}{c}1 \\
3 / 04 \mathrm{~g}\end{array}$ & - & - & $\begin{array}{c}1.1 \\
1 / .6\end{array}$ \\
\hline 3 & 5 & 95-105 & $99.15-99.05$ & - & - & $\begin{array}{l}2 \\
1\end{array}$ & 1 & $\begin{array}{c}1 \\
2 / .3 \mathrm{~g}\end{array}$ & - & - & $\begin{array}{c}.2 \\
1 / 194.9\end{array}$ \\
\hline 3 & 6 & $105-115$ & 99.05-98.95 & - & - & - & - & - & - & - & $\begin{array}{c}.1 \\
2 / 30.4\end{array}$ \\
\hline 3 & 7 & $115-125$ & 98.95-98.85 & - & - & - & - & $\begin{array}{c}1 \\
19 / 2 \mathrm{~g}\end{array}$ & - & 1 & - \\
\hline 3 & 8 & $125-135$ & $98.85-98.75$ & - & - & 4 & - & $\begin{array}{c}1 \\
152.1 \mathrm{~g}\end{array}$ & - & - & - \\
\hline 3 & 9 & $135-145$ & $98.75-98.65$ & - & - & 5 & - & $1 / .05$ & - & - & - \\
\hline 3 & 10 & $145-155$ & $98.65-98.55$ & - & - & - & - & 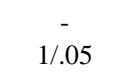 & & & $\begin{array}{c}.1 \\
1 / 1.2\end{array}$ \\
\hline 3 & 12 & $165-175$ & 98.45-98.35 & - & - & - & - & $1 / .4$ & & & - \\
\hline 3 & 13 & $175-185$ & $98.35-98.25$ & - & - & - & - & $\begin{array}{c}1 \\
9 / .9 \mathrm{~g}\end{array}$ & & & $\begin{array}{c}- \\
1 / 15.0\end{array}$ \\
\hline 3 & 14 & $185-195$ & $98.25-98.15$ & - & - & - & - & - & & & $\begin{array}{c}- \\
5 / 2.1\end{array}$ \\
\hline 4 & 1 & $75-85$ & $99.36-99.26$ & - & 1 & - & - & - & - & - & $\begin{array}{c}.1 \\
9 / 6.3\end{array}$ \\
\hline 4 & 2 & $85-95$ & $99.26-99.16$ & - & - & $\begin{array}{c}2 \\
16\end{array}$ & - & $\begin{array}{c}1 \\
7 / .015 \mathrm{~g}\end{array}$ & - & $\begin{array}{l}3 \\
4\end{array}$ & $\begin{array}{c}1.42 \\
25 / 1.0\end{array}$ \\
\hline 4 & 2 (soil) & $85-90$ & flotation & - & - & $\begin{array}{c}34 \\
4\end{array}$ & - & - & - & - & 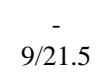 \\
\hline 4 & 4 & $105-115$ & 99.06-98.96 & - & - & - & - & $\begin{array}{l}1 \\
0\end{array}$ & - & - & $\begin{array}{l}.1 \\
1 / .2\end{array}$ \\
\hline 4 & 5 & $115-125$ & 98.96-98.86 & - & - & - & - & $1 / 4 \mathrm{~g}$ & - & - & - \\
\hline 4 & 6 & $125-135$ & 98.86-98.76 & - & - & 1 & - & $\begin{array}{c}1 \\
2 / .05\end{array}$ & - & - & $\begin{array}{l}.1 \\
0\end{array}$ \\
\hline 4 & 7 & $135-145$ & $98.76-98.66$ & - & - & - & - & - & - & - & $\begin{array}{l}.1 \\
1 / .7\end{array}$ \\
\hline 4 & 10 & $165-175$ & $98.46-98.36$ & - & - & - & - & - & - & & $\begin{array}{c}.1 \\
1 / 2.9\end{array}$ \\
\hline
\end{tabular}


Table 15 (cont'd)

\begin{tabular}{|c|c|c|c|c|c|c|c|c|c|c|c|}
\hline $\begin{array}{l}\text { Test } \\
\text { Unit }\end{array}$ & Level & $\begin{array}{c}\text { Depth } \\
(\mathrm{cm} \mathrm{bs})\end{array}$ & Elevation (m) & $\begin{array}{l}\text { Proj. } \\
\text { Point }\end{array}$ & Biface & $\begin{array}{l}\text { Chipped } \\
\text { Stone } \\
\text { Debitage }\end{array}$ & Shell & $\begin{array}{l}\text { Charcoal } \\
\text { Sample/g }\end{array}$ & $\begin{array}{c}\text { Burned } \\
\text { Clay }(\mathrm{g})\end{array}$ & Bone & $\begin{array}{c}\text { Burned } \\
\text { Rock/kg }\end{array}$ \\
\hline 4 & 11 & $175-185$ & $98.36-98.26$ & - & - & - & - & $\begin{array}{c}1 \\
2 / .4 \mathrm{~g}\end{array}$ & - & - & - \\
\hline 5 & 1 & $75-85$ & $99.36-99.26$ & - & - & - & - & - & - & $\overline{3}$ & $\begin{array}{c}.1 \\
1 / 48.9\end{array}$ \\
\hline 5 & 2 & $85-95$ & $99.26-99.16$ & 1 & - & 1 & 1 & $\stackrel{-}{3 / .01 \mathrm{~g}}$ & $\begin{array}{c}2.5 \\
6.5 \mathrm{~g}\end{array}$ & - & $\begin{array}{c}.3 \\
33 / 227.0\end{array}$ \\
\hline 5 & 3 & $95-105$ & $99.16-99.06$ & - & - & - & - & - & - & - & $\begin{array}{c}.3 \\
16 / 457.1\end{array}$ \\
\hline 5 & 4 & $105-115$ & $99.06-98.96$ & - & - & - & - & $\begin{array}{c}1 \\
20 / 35.1 \mathrm{~g}\end{array}$ & - & - & $\begin{array}{l}.01 \\
1 / 1.1\end{array}$ \\
\hline 5 & 6 & $125-135$ & $99.86-98.76$ & - & - & - & - & - & - & - & $\begin{array}{l}.01 \\
1 / .3\end{array}$ \\
\hline 6 & 1 & $79-90$ & $99.49-99.38$ & - & - & 1 & - & - & - & - & - \\
\hline 6 & 3 & $100-110$ & $99.28-99.18$ & - & - & 3 & - & $\begin{array}{c}1 \\
50 / 6 \mathrm{~g}\end{array}$ & - & 3 & $\begin{array}{l}.1 \\
0\end{array}$ \\
\hline 6 & 4 & $110-120$ & $99.18-99.08$ & - & - & $\begin{array}{l}28 \\
26\end{array}$ & - & $\begin{array}{c}1 \\
90 / 33.7 \mathrm{~g}\end{array}$ & 5.0 & $\begin{array}{l}21 \\
28\end{array}$ & $\begin{array}{c}3.1 \\
12 / 40.9\end{array}$ \\
\hline 6 & 4 (soil) & ???110-120 & flotation & - & - & $\begin{array}{l}29 \\
22\end{array}$ & - & $\begin{array}{c}- \\
50 / .375 \mathrm{~g}\end{array}$ & 8.0 & - & - \\
\hline 6 & 5 & $120-130$ & $99.08-98.98$ & - & & - & - & $\begin{array}{c}1 \\
20 / 16.4 \mathrm{~g}\end{array}$ & - & - & $\begin{array}{c}1.1 \\
0\end{array}$ \\
\hline 6 & 6 & $130-140$ & 98.98-98.88 & - & - & 1 & - & - & - & - & $\begin{array}{c}1.5 \\
0\end{array}$ \\
\hline 6 & 7 & $140-150$ & 98.88-98.78 & - & - & - & - & - & - & - & $\begin{array}{l}.3 \\
0\end{array}$ \\
\hline 6 & 9 & $160-170$ & $98.68-98.58$ & - & - & 1 & - & - & - & - & $\begin{array}{l}.5 \\
0\end{array}$ \\
\hline 6 & 11 & $180-190$ & $98.48-98.38$ & - & - & - & - & $\begin{array}{c}1 \\
20 / 11.3\end{array}$ & - & - & $\begin{array}{l}.7 \\
0\end{array}$ \\
\hline 6 & 12 & $190-200$ & $98.38-98.28$ & - & - & - & - & - & - & 3 & $\begin{array}{l}.1 \\
0\end{array}$ \\
\hline 6 & 13 & $200-210$ & $98.28-98.18$ & - & - & - & - & - & - & - & $\begin{array}{c}.01 \\
0\end{array}$ \\
\hline 7 & 2 & $90-100$ & $99.38-99.28$ & - & - & - & - & - & - & - & .1 \\
\hline 7 & 3 (soil) & $100-110$ & $99.28-99.18$ & - & - & - & $\overline{9}$ & $\begin{array}{c}- \\
16 / .01\end{array}$ & - & $\overline{1}$ & $\begin{array}{c}.4 \\
4 / 6\end{array}$ \\
\hline 7 & 4 & $110-120$ & 99.18-99.08 & - & - & 2 & - & $50 / 10.5 \mathrm{~g}$ & $1.1 \mathrm{~g}$ & - & - \\
\hline 7 & 4 (soil) & $110-120$ & $99.18-99.08$ & - & - & $\begin{array}{l}9 \\
0\end{array}$ & - & $\begin{array}{c}1 \\
33 / .095\end{array}$ & $\begin{array}{l}1.5 \\
.2\end{array}$ & - & $\begin{array}{c}17 \\
14 / 2\end{array}$ \\
\hline 7 & 5 & $120-130$ & $99.08-98.98$ & - & - & - & - & $\begin{array}{c}1 \\
15 / 4.4\end{array}$ & - & - & $\begin{array}{l}.1 \\
0\end{array}$ \\
\hline 7 & 7 & $140-150$ & 98.88-98.78 & - & - & 1 & - & $\begin{array}{c}1 \\
26 / 7\end{array}$ & $\begin{array}{c}10.5 \\
0\end{array}$ & - & $\begin{array}{c}.5 \\
12 / 9.7\end{array}$ \\
\hline 7 & 8 & $150-160$ & $98.78-98.68$ & - & - & 1 & - & $\begin{array}{c}1 \\
28 / 18.9\end{array}$ & - & - & $\begin{array}{l}1 \\
0\end{array}$ \\
\hline 8 & 3 & 95-105 & $99.33-99.23$ & - & - & - & - & - & $\begin{array}{l}.1 \\
0\end{array}$ & - & $\begin{array}{c}.01 \\
2 / 12.4\end{array}$ \\
\hline 8 & 4 & $105-115$ & $99.23-99.13$ & - & - & - & - & $\begin{array}{c}1 \\
50 / 5.2\end{array}$ & $\begin{array}{l}.3 \\
.2\end{array}$ & - & $\begin{array}{c}0.1 \\
23 / 521.1\end{array}$ \\
\hline 8 & 5 & $115-125$ & $99.13-99.03$ & - & - & - & - & $\begin{array}{c}1 \\
2 / .2\end{array}$ & 30.5 & 1 & $\begin{array}{c}.1 \\
35 / 141.1\end{array}$ \\
\hline 8 & 6 & $125-135$ & $98.93-98.83$ & - & - & 1 & - & - & $\begin{array}{c}1.8 \\
.7\end{array}$ & - & $\begin{array}{c}.1 \\
3 / .9\end{array}$ \\
\hline
\end{tabular}


Table 15 (cont'd)

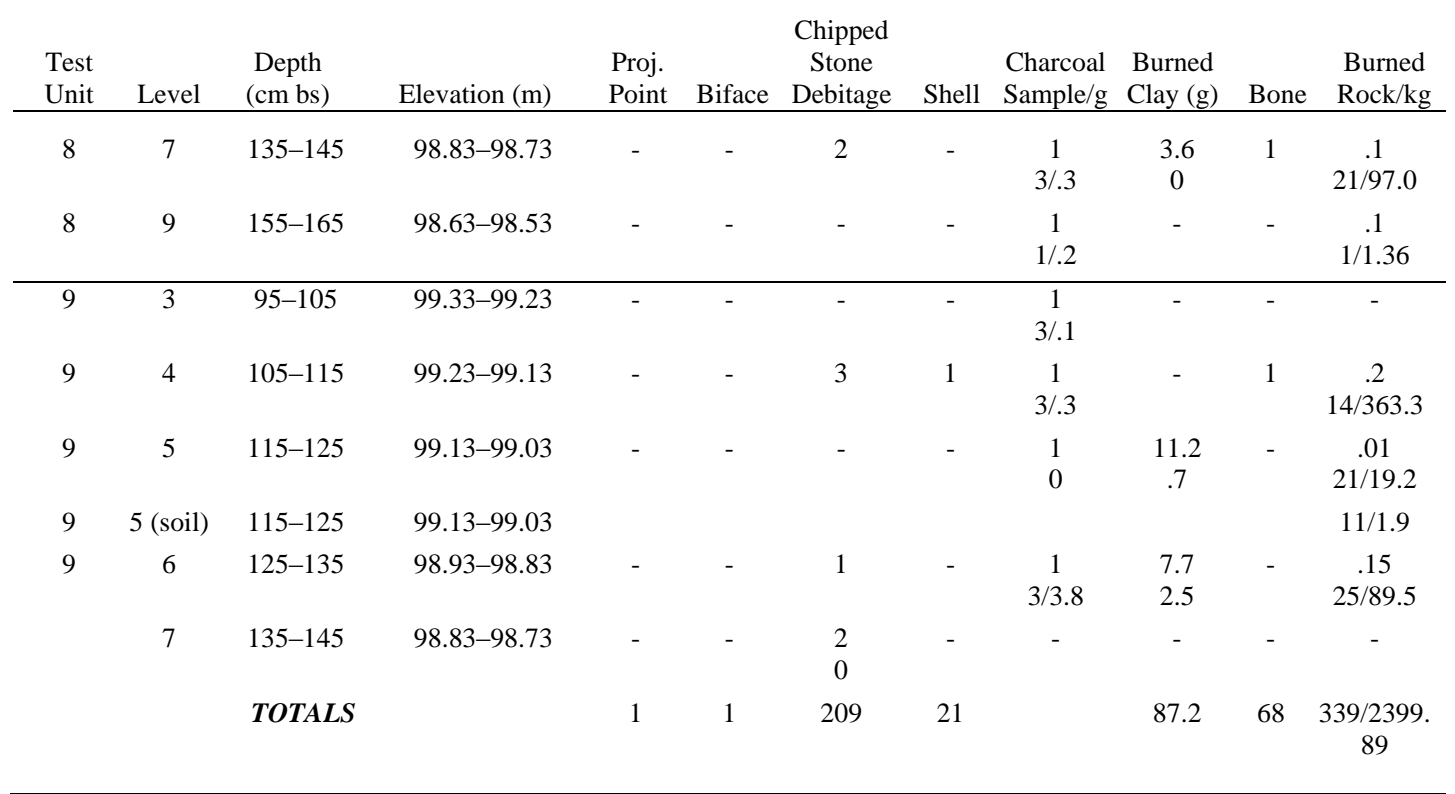

\section{Test Unit $2(99.69-97.87$ m Elevation [58-240 cm bs])}

Test Unit 2 was excavated at 41BT427 adjacent to Trench 11 to test an area along the north trench profile that exposed a bivalve shell as well as a burned rock. Charcoal flecking was observed in the trench wall and during hand excavation between $70 \mathrm{~cm}$ to $210 \mathrm{~cm}$ bs $(99.57-$ $98.17 \mathrm{~m}$ ) with a concentration near $210 \mathrm{~cm}$ bs $(98.17 \mathrm{~m})$, just above a sand layer. Only one chipped stone flake was collected during excavation from Level 5 (99.27-99.17 m) (see Table $15)$.

\section{Test Unit 3 (99.55-98.15 m Elevation [55-195 cm bs])}

Test Unit 3 was excavated adjacent to Trench 12 at site 41BT427. Although no cultural material was observed in the profiles of Trench 12, this area required testing to determine the presence of cultural material that escaped notice or was simply not exposed in profile. During excavation charcoal was observed throughout the profile. Large pieces were periodically collected as samples, though unassociated with cultural material. A total of 15 chipped stone flakes was recovered in this unit; three from Levels 1 and 2 (99.55-99.35 m), three from Level 5 (99.15$99.05 \mathrm{~m}$ ), and nine from Levels 8 and $9(98.85-98.65 \mathrm{~m}$ ) (see Table 15). One fragment of mussel shell was collected from Level 5. One fragment of bone was collected from Level 7 (98.95$98.85 \mathrm{~m})$.

\section{Test Unit 4 (99.36-98.26 m Elevation [75-185 cm bs])}

Test Unit 4 at 41BT427 was excavated adjacent to Trench 10 over a cluster of three burned rocks observed in the north profile at $80-85 \mathrm{~cm}$ bs $(99.31-99.26 \mathrm{~m})$. Feature 1 was identified in this unit and consisted of a small cluster of burned, friable limestone, chipped stone flakes, and a 
small amount of animal bone in Test Unit 4 along Trench 10 between 85 and $90 \mathrm{~cm}$ bs $(99.26-$ $99.21 \mathrm{~m}$ ) (Figure 19). Although one basal fragment of a biface was collected from Level 1, the majority of cultural material was recovered from Level 2 (99.26-99.16 m) (Figure 20). This included 56 chipped stone flakes (34 recovered from flotation) and seven bone fragments (see Table 15).

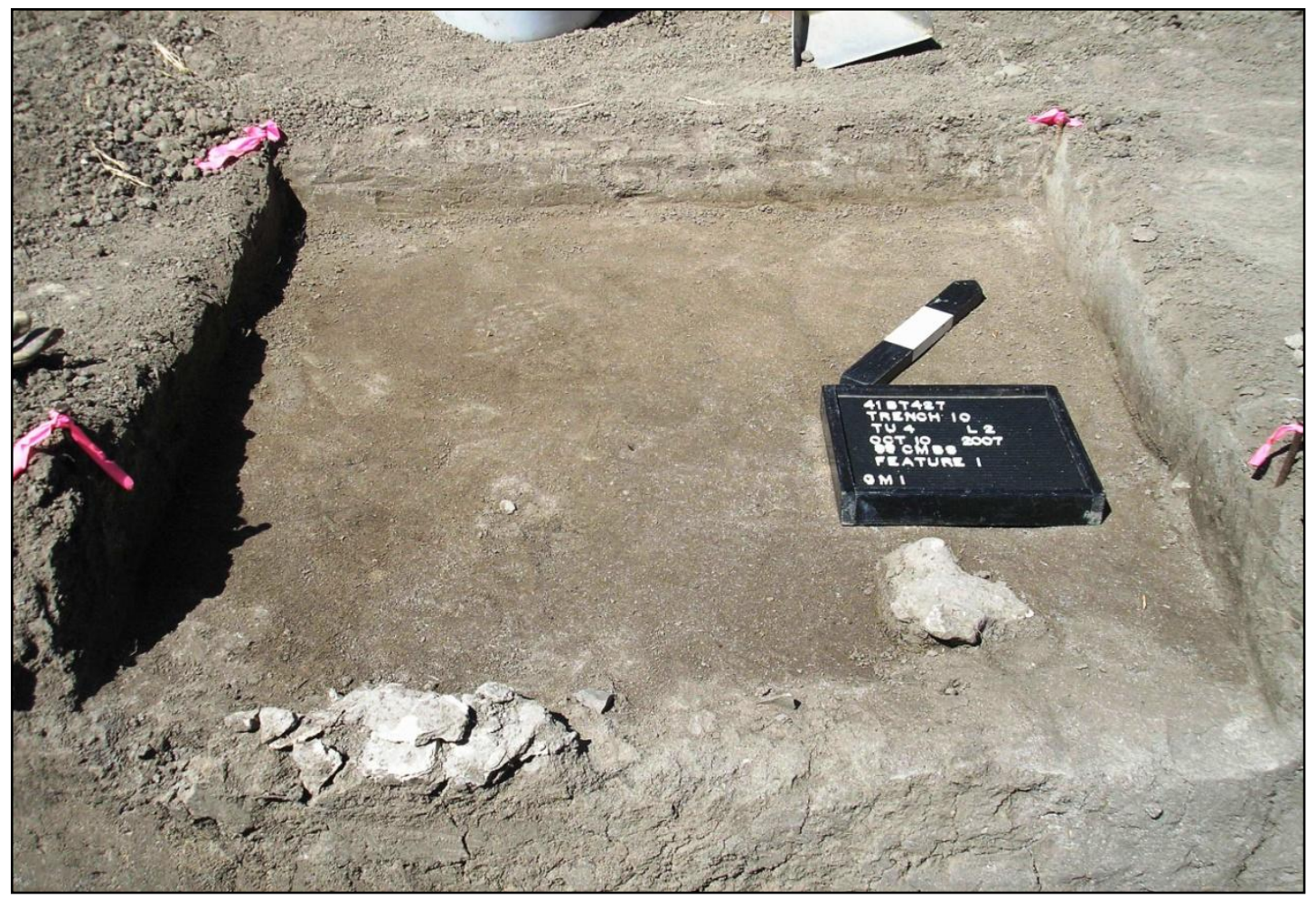

Figure 19. Feature 1 rock cluster in Test Unit 4, photographer is facing north-northwest.

The biface fragment was made from a gray, fine-grained chert with pale inclusions similar to common Edwards chert varieties. The extant piece has a $27.5-\mathrm{mm}$ maximum width, a $25-\mathrm{mm}$ maximum length, and a 6-mm maximum thickness.

Even though charcoal flecking was observed in the level containing Feature 1, only one larger piece of charcoal could be collected. This charcoal was submitted for radiocarbon dating (Beta 236942) and produced a 2 sigma calibrated result of A.D. 650 to 780 (Cal BP 1300 to 1170) (Appendix C). In addition, very small flecks of burned earth were observed throughout the soil matrix.

Below the Feature 1 occupation zone, materials were scattered throughout the profile. One chipped stone flake was recovered from Level 6 (98.86-98.76 m) (Figure 21; see Table 15). 


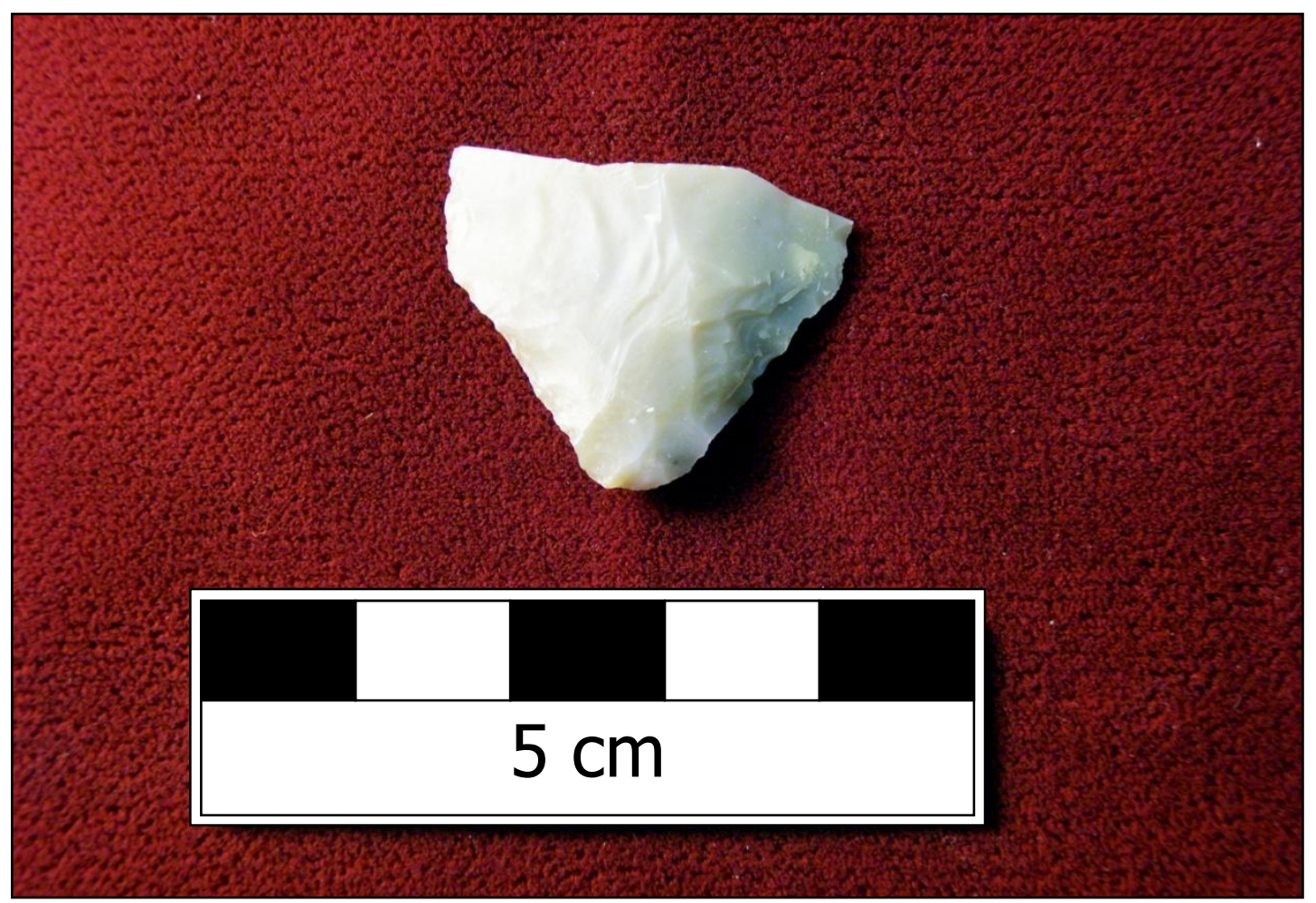

Figure 20. Basal fragment of a biface recovered in Test Unit 4, Level 1 (99.36-99.26 m).

\section{Test Unit 5 (99.36-98.66 m Elevation [75-145 cm bs])}

Test Unit 5 at 41BT427 was excavated adjacent to Trench 10 and on the east side of Test Unit 4. This unit was opened up to test the apparent concentration in Levels 1 and 2 (99.36-99.16 m) that was observed in Test Unit 4 and to test the location of an additional burned rock observed in the trench profile. The density of artifacts recovered from the levels adjacent to Feature 1 was much lower than observed in Test Unit 4. One chipped stone flake and one diagnostic tool were recovered from Level $2(99.26-99.16 \mathrm{~m})$ in addition to one piece of shell and $2.5 \mathrm{~g}$ of burned clay (see Table 15).

The only diagnostic artifact recovered during this investigation was found in this unit. The basal portion of a medium-sized dart point was recovered from $88 \mathrm{~cm}$ bs (Level 2) in Test Unit 5 (Figure 22). The projectile point base is broken along a lateral edge and across the blade. This point is barbed with a bifurcated base. The fracture removed one barb. The stem is straight and the base is thinned but does not appear to be ground. This tool was made from a gray to tan chert with inclusions that appear common in many varieties of Edwards chert. The stem width is $18 \mathrm{~mm}$, total extant length is $30 \mathrm{~mm}$, and stem length is $13 \mathrm{~mm}$; projected maximum width would be $31 \mathrm{~mm}$ if this point was roughly symmetrical prior to breakage. 


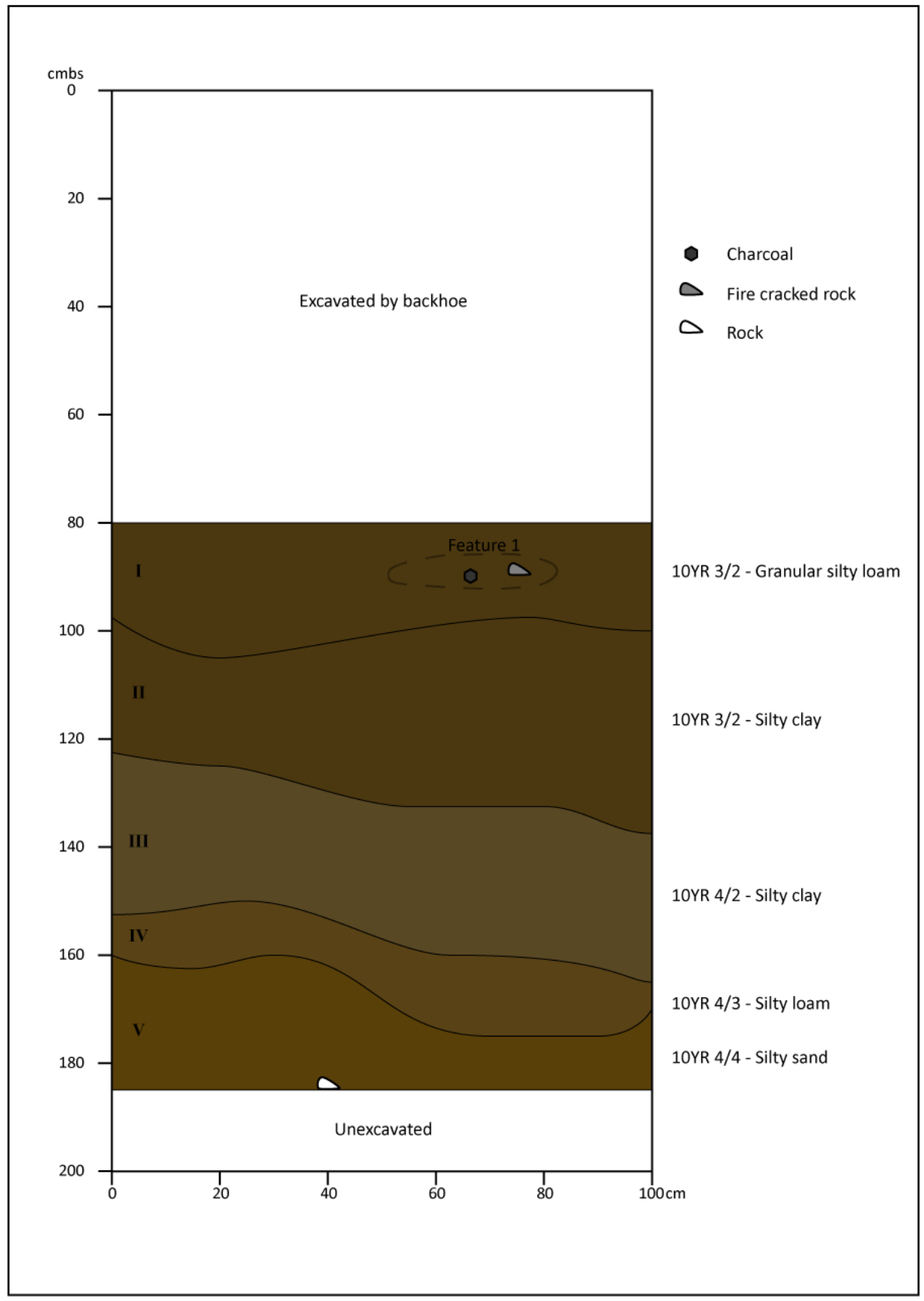

Figure 21. Profile of the northeast wall of Trench 10, site 41BT427. 


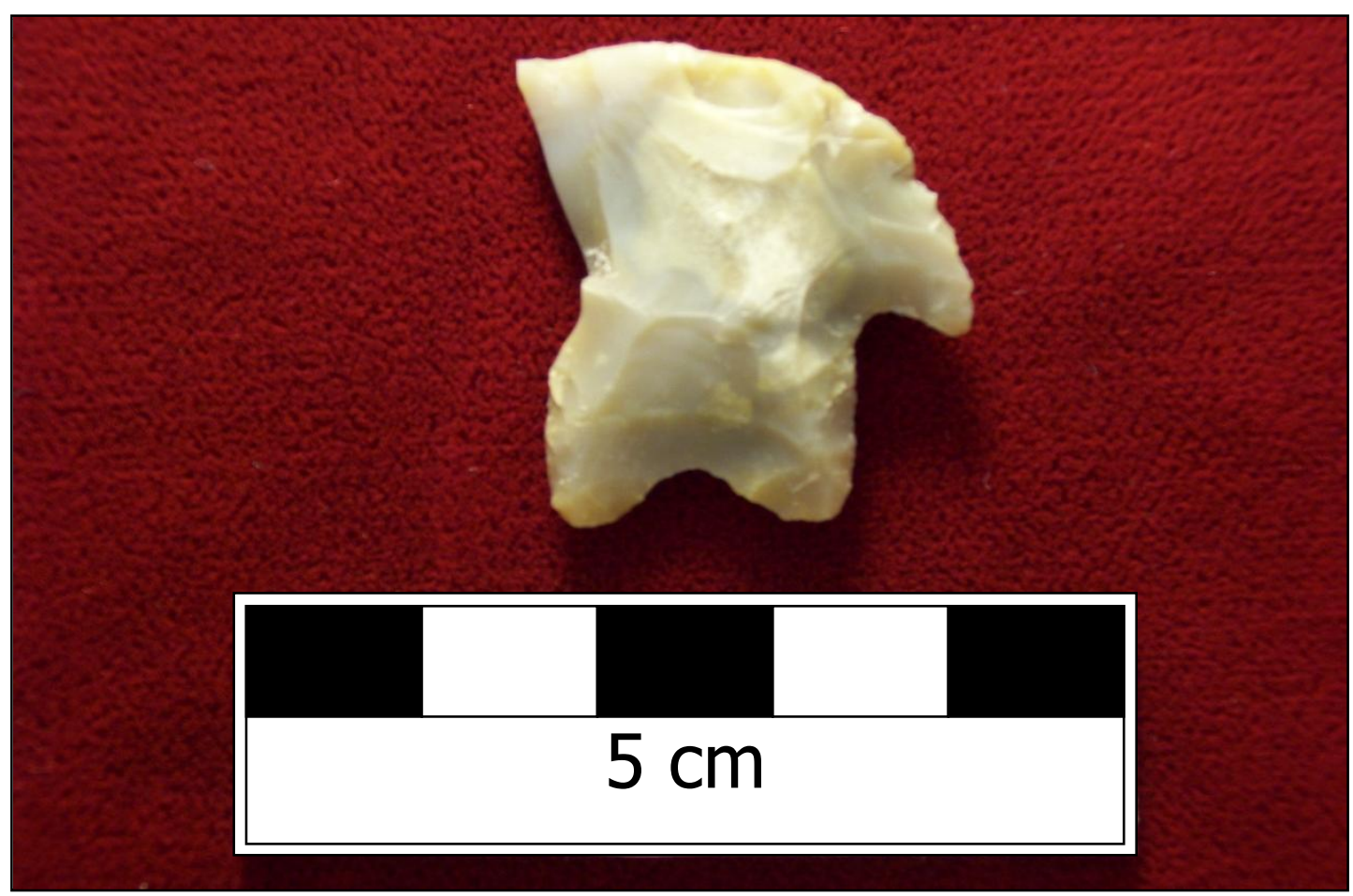

Figure 22. Dart point fragment recovered from Test Unit 5, Level 2 (99.26-99.16 m).

\section{Test Unit 6 (99.49-98.18 m Elevation [76-210 cm bs])}

Test Unit 6 was excavated adjacent to Trench 13 to test two large burned rocks that were exposed in the north trench wall at approximately $90 \mathrm{~cm}$ bs $(99.38 \mathrm{~m})$. Again, one clear occupation zone was recorded. A cluster of burned and unburned rock was recorded and photographed in Level 4 (Figure 23). A total of 108 pieces of chipped stone debitage were collected from Levels 3 and 4 (99.28-99.08 m), with 105 coming from Level $4(99.18-99.08 \mathrm{~m})$ alone (51 were from flotation samples). In addition, $34 \mathrm{~g}$ of burned clay were collected from Level 4, 49 fragments of animal bone were recovered from Level 4 and 3 fragments from Level 3 (99.28-99.18 m) (see Table 15). Charcoal from Level 4 was collected and submitted for radiocarbon dating (Beta 236943) and resulted in a 2 sigma calibrated age of A.D. 660 to 780 (Cal BP 1290 to 1160) (Appendix C).

Below this occupation zone, artifact recovery was sparse (Figure 24). One flake each was recovered from Levels $6(98.98-98.88 \mathrm{~m})$ and $9(98.68-98.58 \mathrm{~m})$, and three bone fragments were recovered from Level 12 (98.38-98.28 m) (see Table 15).

\section{Test Unit 7 (99.49-98.58 m Elevation [77-170 cm bs])}

Test Unit 7 was one of three test units placed adjacent to Trench 13 and west of Test Unit 6 to further explore the occupation zone that was recorded in Level 4 of TU $6(99.18-99.08 \mathrm{~m})$. Several large rocks were exposed in Levels 3 and $4(99.28-99.08 \mathrm{~m})$ and 11 chipped stone flakes and $2.6 \mathrm{~g}$ of burned clay were collected from Level 4 (Figure 25). Below the Level 4 occupation zone, one flake each was recovered from Level 7 (98.88-98.78 m) and Level 8 (98.78-98.68 m), and $10.5 \mathrm{~g}$ of burned clay were collected from Level 7. 


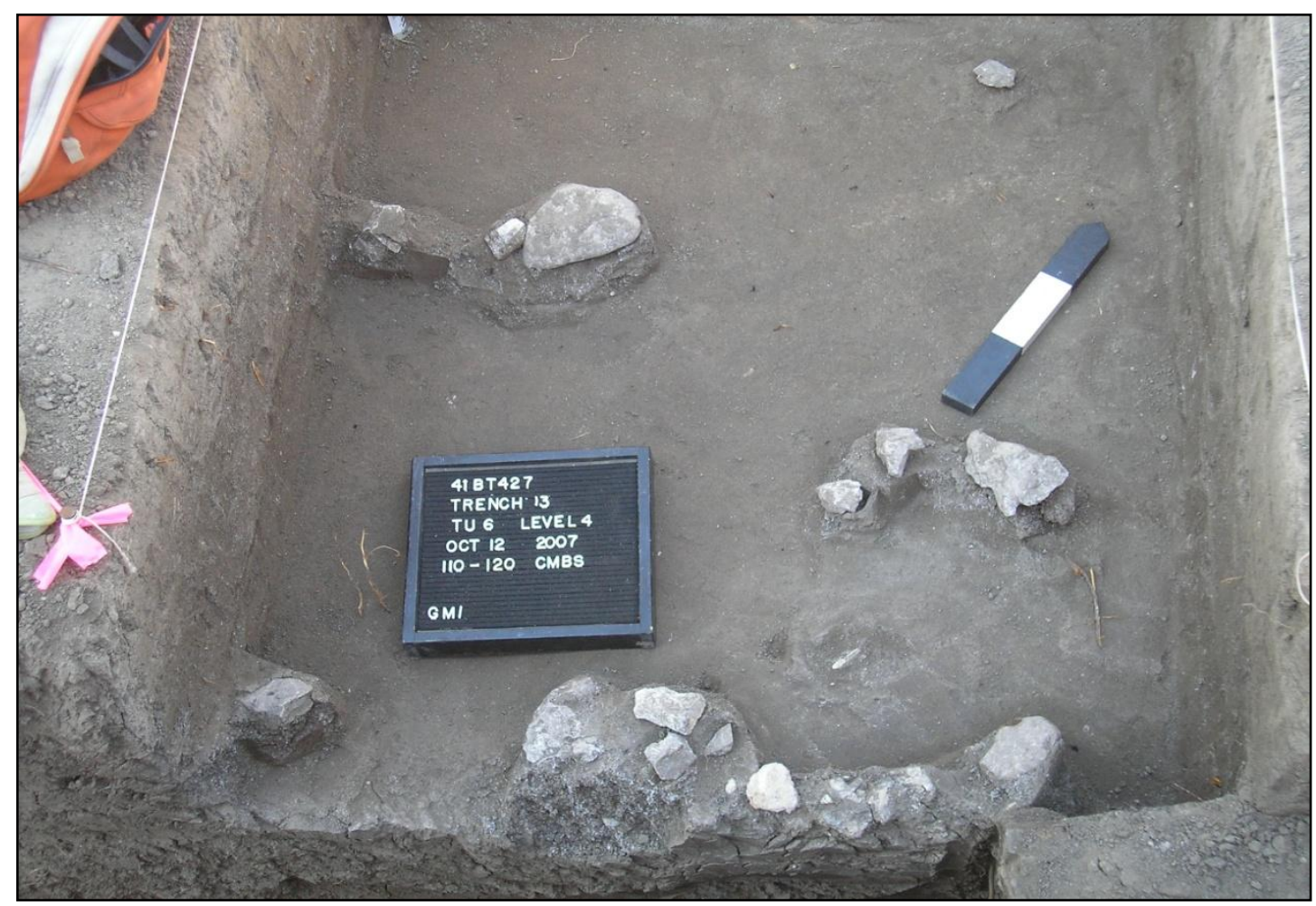

Figure 23. Cluster of burned and unburned rocks in Level 4, Test Unit 6.

\section{Test Unit 8 (99.53-98.63 m Elevation [75-165 cm bs])}

Test Unit 8 was excavated just west of Test Unit 7 to further expose the occupation zone at approximately $99.18-99.08 \mathrm{~m}$. Recovery was much lower in this unit than in Test Units 6 and 7. No chipped stone was recovered in the upper five levels of Test Unit 8. However, $40.0 \mathrm{~g}$ of burned clay were collected from Levels 3, 4, and $5(99.33-99.03 \mathrm{~m})$, and one bone fragment was recovered in Level $5(99.13-99.03 \mathrm{~m})$. Three chipped stone flakes and $6.1 \mathrm{~g}$ of burned clay were recovered from Levels 6 and $7(99.03-98.83 \mathrm{~m})$. The artifact density recorded for Test Unit 8 is very low and does not reflect the density observed elsewhere on site in association with the thin occupation zone.

\section{Test Unit 9 (99.53-98.73 m Elevation [75-155 cm bs])}

Test Unit 9 was excavated just west of Test Unit 8 along the north wall of Trench 13. Six chipped stone flakes were recovered in this unit: three in Level $4(99.23-99.13 \mathrm{~m})$, one in Level 6 $(99.03-98.93 \mathrm{~m})$, and two in Level $7(98.93-98.83 \mathrm{~m})$. In addition, $22.1 \mathrm{~g}$ of burned clay were collected from Levels 5 and $6(99.13-99.03 \mathrm{~m})$. Similar to Test Unit 8, the artifact density is much lower than it was in units excavated further to the east. The occupation zone recorded elsewhere on site is not reflected by cultural material distribution in this unit. 


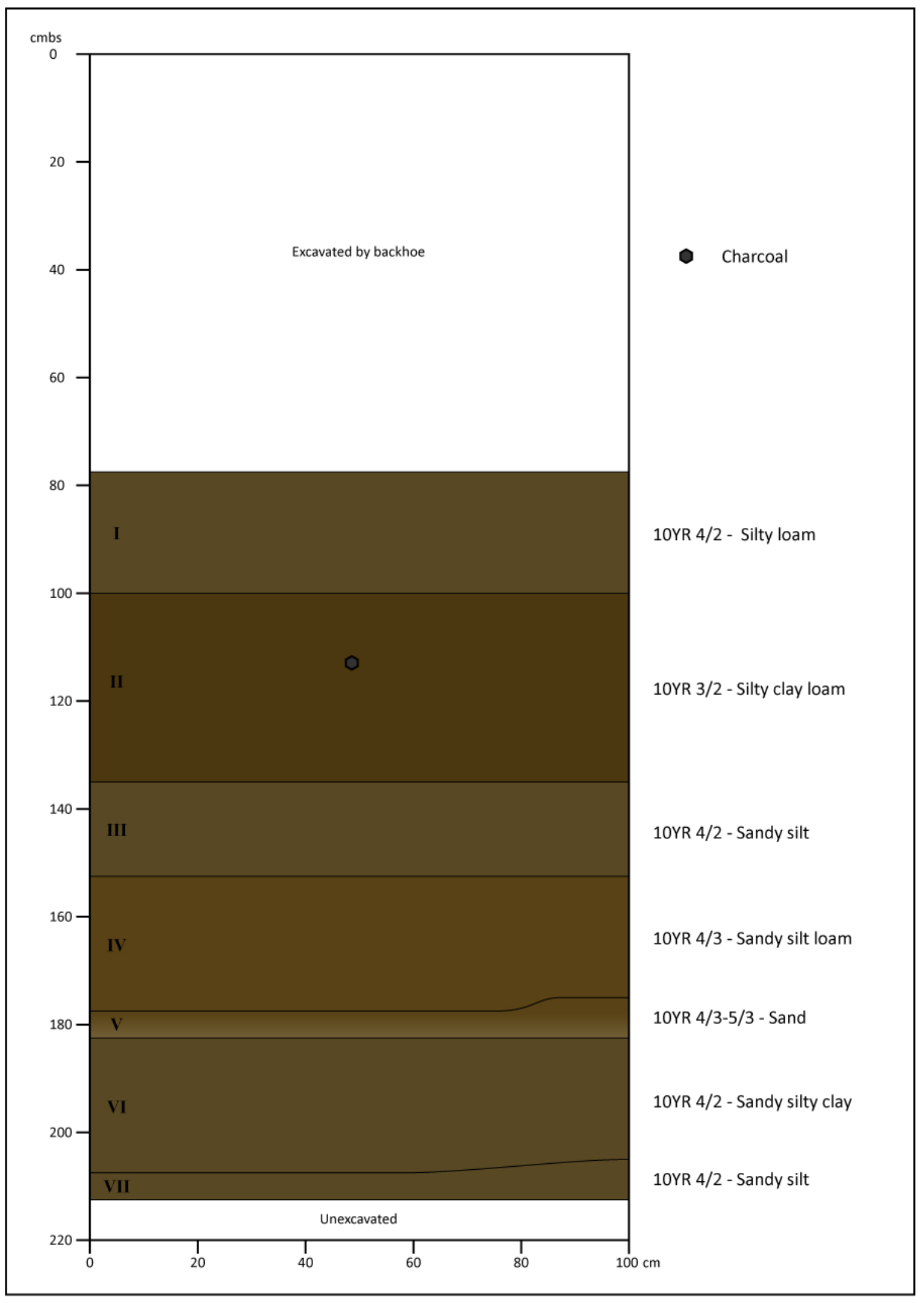

Figure 24. Profile of the northwest wall of Trench 13, Unit 6. 


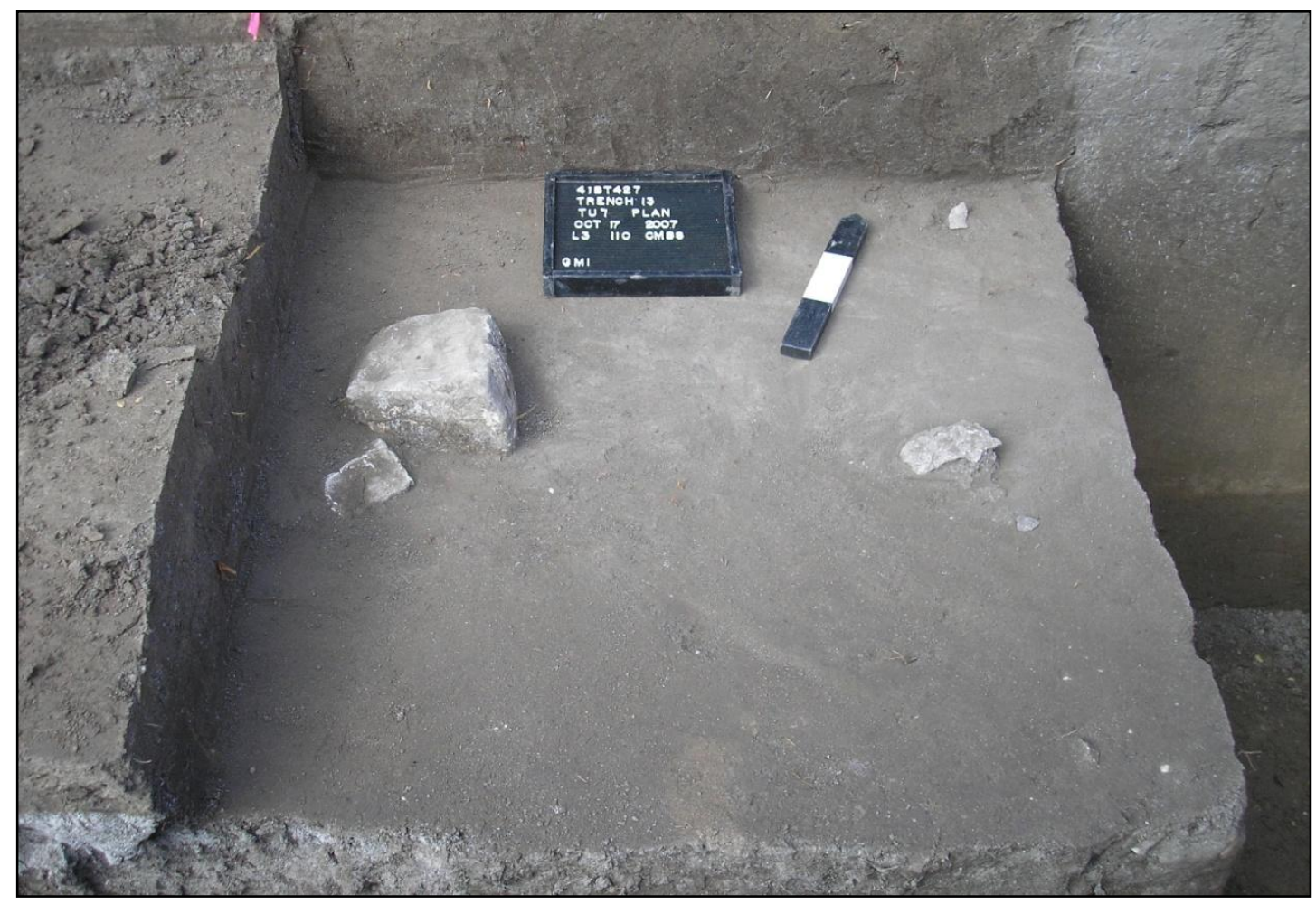

Figure 25. Base of Level 3 with several large rocks exposed.

\section{Summary of Excavations}

The excavation of four mechanical trenches and eight hand-excavated units (8.94 cubic $\mathrm{m}$ ) at site 41BT427 resulted in the identification of only one definable cultural component. This occupation zone appears to lie on a natural surface that slopes down toward North Rocky Creek to the west. The material expression of this occupation was most abundant and apparent in Test Unit 4, Level 2, Feature $1(99.26-99.16 \mathrm{~m})$, as well as in Test Unit 6, Level $4(99.18-99.08 \mathrm{~m})$. This indicates only an 8-cm slope of this surface over a distance of approximately $36 \mathrm{~m}$. Charcoal samples from both of these levels were submitted for radiocarbon dating (Beta 236942 and 236943) and produced 2 sigma calibrated results of A.D. 650 to 780 (Cal BP 1300 to 1170) and A.D. 660 to 780 (Cal BP 1290 to 1160). Both AMS dates are consistent with the transitional Late Archaic to Late Prehistoric period in Central Texas. No diagnostic cultural material was collected from the test unit or backhoe trench excavations. It appears that site 41BT427 represents an ephemeral, shortterm campsite used by hunter-gatherers, perhaps during a brief foray for resource exploitation along North Rocky Creek.

\section{LABORATORY ANALYSES}

The following describes the analyses of all artifacts recovered from the testing of 41BT427. Table 15 quantifies the materials (lithics, shell, vegetal sample, burned clay, bone, and firecracked rock) from each of the test units by depth. Detailed discussions of the individual artifact classes follow below. 


\section{Faunal Remains}

The recovered faunal remains from 41BT427 totaled 50 unworked fragments with 39 unidentified. The identified fragments included three specimens of Small Terrestrial Mammal, one specimen of Medium Terrestrial Mammal, one specimen each of Large Terrestrial Mammal and Canis sp., three molluscan specimens, and two unidentifiable specimens of fish (Table 16). Overall, the faunal sample from site 41BT427 was small, poorly preserved and provides little information concerning prehistoric subsistence patterns.

Table 16

Faunal Remains from 41BT427

\begin{tabular}{lc}
\hline Small Terrestrial Mammal & $\mathrm{n}=3$ \\
Medium Terrestrial Mammal & $\mathrm{n}=1$ \\
Large Terrestrial Mammal & $\mathrm{n}=1$ \\
Canis sp. & $\mathrm{n}=1$ \\
Fish sp. & $\mathrm{n}=2$ \\
Mollusca & $\mathrm{n}=3$ \\
Unidentified & $\mathrm{n}=39$ \\
& Total $\mathbf{5 0}$ \\
\cline { 2 - 2 }
\end{tabular}

\section{Botanical Remains}

Macrobotanical remains recovered by flotation are given in Tables 17 and 18 by count and weight, respectively. Table 19 lists uncarbonized seeds on a presence/absence basis.

\section{Carbonized Plant Remains}

\section{Wood Charcoal}

A total of 80 fragments weighing $1.48 \mathrm{~g}$ was recovered and 47 fragments were identified (see Table 17). Eleven wood fragments (23 percent) were too small or in too poor condition to be identified more specifically than as a hardwood. Interestingly, oaks make up only 23 percent of the assemblage. Even if all indeterminable fragments were oak, it would still make up less than half the assemblage. Oak typically comprises 60-80 percent of the wood charcoal in burned rock features in Central Texas (Bush 2009, 2010; Mehalchick et al. 2004). Most likely, inhabitants at41BT427 were collecting wood for fuel from the riparian environment in the immediate site area, where pecan, elm, ash, sycamore, and willow or cottonwood are more common than oaks, which dominate the uplands. Although pecan burns nearly as hot as oak and makes good coals, the other woods recovered are of considerably lower quality as firewood. Juniper is absent from the archeological assemblage, both because it is a relatively poor fuelwood and because it would have been restricted to ravines and limestone outcrops in pre-agricultural times (Fonteyn et al. 1988:88). 
Table 17

Carbonized Plant Remains from 41BT427 by Count

Plant Remains

FS\# / Count

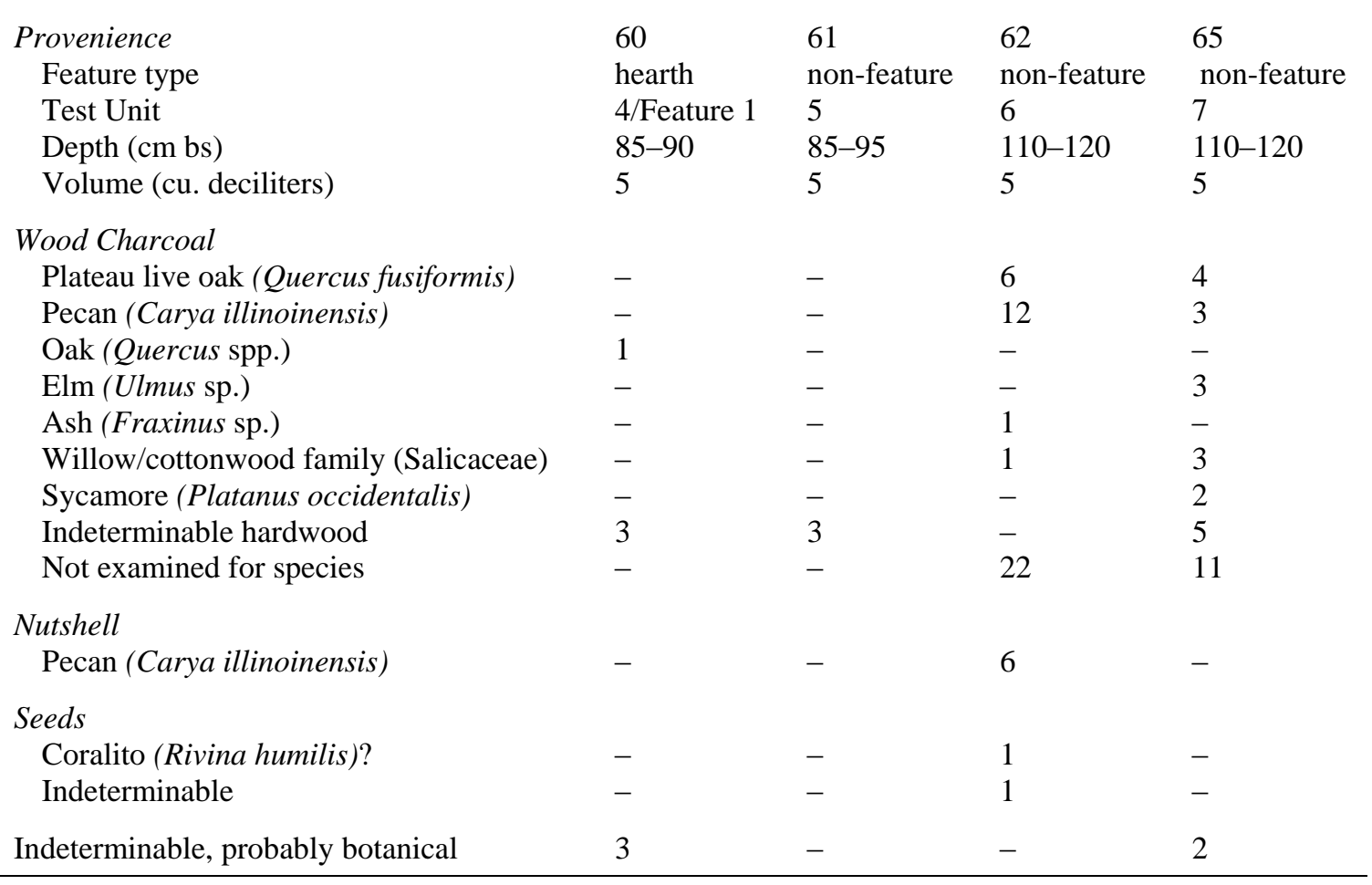

Table 18

Carbonized Plant Remains from 41BT427 by Weight

Plant Remains

FS\# / Weight (in grams)

\begin{tabular}{|c|c|c|c|c|}
\hline Provenience & 60 & 61 & 62 & 65 \\
\hline Feature type & hearth & non-feature & non feature & non-feature \\
\hline Test Unit & 4/Feature 1 & 5 & 6 & 7 \\
\hline Depth (cm bs) & $85-90$ & $85-95$ & $110-120$ & $110-120$ \\
\hline Volume (cu. deciliters) & 5 & 5 & 5 & 5 \\
\hline \multicolumn{5}{|l|}{ Wood Charcoal } \\
\hline Plateau live oak (Quercus fusiformis) & - & - & 0.03 & 0.02 \\
\hline Pecan (Carya illinoinensis) & - & - & 0.09 & 0.01 \\
\hline Oak (Quercus spp.) & 0.01 & - & - & - \\
\hline Elm (Ulmus sp.) & - & - & - & 0.01 \\
\hline Ash (Fraxinus sp.) & - & - & 0.04 & - \\
\hline Willow/cottonwood family (Salicaceae) & - & - & 1.00 & 0.01 \\
\hline Sycamore (Platanus occidentalis) & - & - & 0.01 & 0.01 \\
\hline Indeterminable hardwood & 0.01 & 0.01 & & 0.01 \\
\hline Not examined for species & - & - & 0.19 & 0.02 \\
\hline
\end{tabular}


Table 18 (cont'd)

\begin{tabular}{lllll} 
Plant Remains & \multicolumn{5}{c}{ FS\# / Weight (in grams) } \\
\hline Nutshell & & & 0.01 & - \\
$\quad$ Pecan (Carya illinoinensis) & - & - & & \\
Seeds & & & 0.01 & - \\
$\quad$ Coralito (Rivina humilis)? & - & - & 0.01 & - \\
$\quad$ Indeterminable & - & - & - & 0.01 \\
$\quad$ Indeterminable, probably botanical & 0.01 & - &
\end{tabular}

Table 19

Uncarbonized Seeds from 41BT427

\begin{tabular}{lllll} 
Plant Remains & \multicolumn{5}{c}{ FS\# / Presence/Absence } \\
\hline Provenience & 60 & 61 & 62 & 65 \\
Depth (cm bs) & $85-90$ & $85-95$ & $110-120$ & $110-120$ \\
Volume (cu. deciliters) & 5 & 5 & 5 & 5 \\
Presence/Absence & & & & \\
Grass family (Poaceae ) & $\mathrm{X}$ & - & $\mathrm{X}$ & $\mathrm{X}$ \\
Mesquite (Prosopis sp.) & - & - & - & $\mathrm{X}$ \\
Hackberry (Celtis sp.) & - & - & - & $\mathrm{X}$ \\
Sandmat (Chamaesyce sp.) & - & - & - & $\mathrm{X}$ \\
Unknown (samara, 7 mm) & - & $\mathrm{X}$ & - & - \\
\hline
\end{tabular}

\section{Nutshell}

Six fragments of pecan nutshell were recovered from FS\#62. Pecan nutshell is unlikely to have been carbonized incidental to the burning of pecan wood, since pecan nuts do not cling to the tree branches as the hulls do. Rather, it represents a probable ancient food resource for inhabitants of the site. Grant Hall (2000:109-110) points out that the fat in pecan nuts may have been critical to hunter-gatherers who relied on lean meat for a portion of the year. Nutritional data for pecans are given in Table 20.

\section{Seeds}

Two seeds were recovered from Test Unit 6. One seed is approximately one-third complete and cannot be identified. The other seed is saucer-shaped, $1.5 \mathrm{~mm}$ in diameter, sparsely papillate in texture, with a triangular hilum nearly identical to that of pokeweed (Phytolacca americana). An identification of coralito (Rivina humilis) is suggested. Coralito, also called pigeon-berry or rougeplant, is a more delicate relative of pokeweed that grows in woodlands near streams. It has smaller seeds than pokeweed. The seed texture is described as hairy (Diggs et al. 1999:882), whereas pokeweed seeds are smooth. Both pokeweed and coralito are considered toxic, but their berries make excellent red dyes (Correll and Johnston 1970; Tull 1987). 
Table 20

Nutrient Values for Pecan Nuts per 100 g Edible Portion

\begin{tabular}{lr}
\hline Water $(\mathrm{g})$ & 3.52 \\
Energy $(\mathrm{kcal})$ & 691.00 \\
Energy $(\mathrm{kj})$ & 2889.00 \\
Protein $(\mathrm{g})$ & 9.17 \\
Total lipid $(\mathrm{g})$ & 71.97 \\
Ash $(\mathrm{g})$ & 1.49 \\
Carbohydrate, by difference $(\mathrm{g})$ & 13.86 \\
\hline
\end{tabular}

Source: U.S. Department of Agriculture, Agricultural Research Service 2009

Macroflora from site 41BT427 show selection of wood in the immediate vicinity of the site for fuel despite the relatively low fuel value of some of those taxa. Test Unit 6 also yielded pecan nutshells, indicating exploitation of nut resources that may have provided valuable dietary fat.

\section{Uncarbonized Plant Remains}

Most uncarbonized plant remains at 41BT427 appear in the form of rootlets that are clearly modern and not reported here. In addition, five types of uncarbonized seeds were recovered in flotation (see Table 19). Uncarbonized seeds are a common occurrence on most archeological sites, but they usually represent seeds of modern plants that have made their way into the soil either through their own dispersal mechanisms or by faunalturbation, floralturbation, or argilliturbation (Bryant 1985:51-52; Keepax 1977; Miksicek 1987:231-232). In all except the driest areas of North America, uncarbonized plant material on open-air sites can be assumed to be of modern origin unless compelling evidence suggests otherwise (Lopinot and Brussell 1982; Miksicek 1987:231). Although site 41BT427 has offered no such evidence and the seeds are interpreted as modern seed rain, one taxon — hackberry - however, merits further discussion.

Unlike the other uncarbonized seeds from site 41BT427, hackberry seeds are known to persist for many centuries in the soil. Hackberry's high resistance to decay presents particular interpretive difficulties on archeological sites. What archeologists typically recover is the hackberry endocarp, the thick white seedcoat from under the under thin fleshy layer of the fruit. The endocarp has a high mineral content: It contains 40-70 percent aragonite, a crystalline form of calcium carbonate (Wang et al. 1997; Yanovsky et al. 1932). The carbonate helps hackberry endocarps preserve unusually well in the soil, and it makes hackberry endocarps excellent candidates for dating of the geological sediments in which they originated. Yang Wang and colleagues argue that dating of sediments by hackberry inclusions is preferable to other methods. Since the carbonates form over a single growing season, their initial ${ }^{14} \mathrm{C}$ content is the same as that in the atmosphere, and they can be tested for reliability before dating (Wang et al. 1997:342). Hackberry endocarps are surprisingly common in geological and archeological strata (Wang et al. 1997:337), but they are not necessarily archeological in origin. The difficulty for archeobotanists is determining whether the hackberry endocarps represent the traces of human hackberry use or merely the presence of hackberries at the site location (or the location at which the site sediments originated). 
The single, whole hackberry seed from FS\#65 at 41BT427 is white in color and therefore has not been exposed to the cultural agent of fire as the demonstrably ancient plants have. Most likely, it represents recent seed rain. Hackberry fruits are a candidate for ancient plant exploitation at 41BT427, however, because they were likely present near the confluence of North Rocky Creek and South Rocky Creek in prehistoric times and were widely used by historic people (Moerman 1998). Nonetheless, the particular hackberry observed in the samples probably does not represent the archeological traces of this activity.

\section{Chipped Stone Tools and Debitage}

The lithic assemblage from site 41BT427 consists of one biface fragment and a dart projectile point fragment (see discussions for Test Units 4 and 5, respectively). The 103 pieces of debitage (102 reduction flakes and one piece of shatter) are of various sizes and were quantified by size, raw materials, and heated/not heated categories (Table 21).

Table 21

41BT 427 Lithic Debitage Sorted by Size, Raw Material, and Heated

\begin{tabular}{rrrrrrr} 
Size $(\mathrm{mm})$ & Quantity & \multicolumn{2}{c}{ Material } & \multirow{2}{*}{ Not heated } \\
\cline { 3 - 6 } & & Edwards Chert & Limestone & Quartzite & Undifferentiated Chert & 13 \\
$0-6.4$ & 29 & 6 & 0 & 2 & 21 & 9 \\
$6.4-12.7$ & 29 & 15 & 0 & 8 & 6 & 5 \\
$12.7-19$ & 17 & 7 & 0 & 5 & 10 & 6 \\
$19-25.4$ & 20 & 3 & 1 & 6 & 4 & 5 \\
$25.4-38.1$ & 7 & 2 & 1 & 0 & 0 & 1 \\
$38.1-50.8$ & 1 & 1 & 0 & 0 & 43 & 41 \\
Total & 103 & 34 & 2 & 21 & & 5 \\
\hline
\end{tabular}

The majority of the lithic debitage was $19 \mathrm{~mm}$ or smaller with just less than a third of the total assemblage being larger. Among the the debitage, the majority was made from chert (42 percent from undifferentiated chert, 33 percent from fine-grained Edwards chert), 20 percent from quartzite, and a negligible 0.02 percent from limestone. The majority of the assemblage (60 percent) showed some indication (discolored, fractured, or potlidded) of having been affected by fire to some degree.

\section{Baked Clay}

Irregular masses of fire-hardened clay were collected during the excavation and returned to the lab for basic quantification (Table 22). The total number of baked clay masses only totaled 22 and all were relatively small at less than $19 \mathrm{~mm}$. Among the collection, only one specimen was found to be impressed daub (Test Unit 8, 125-135 cm bs), with the others showing no indication of impressions. The baked clay specimens were found in Test Units 5, 8, and 9 (85-135 cm bs), as well as from the soil samples taken from Test Units 6 and $7(100-122 \mathrm{~cm} \mathrm{bs})$. 
Table 22

41BT 427 Baked Clay Sorted by Size

Size $(\mathrm{mm}) \quad$ Quantity

\begin{tabular}{rl} 
Size $(\mathrm{mm})$ & Quantity \\
$0-6.4$ & 7 \\
$6.4-12.7$ & 13 \\
$12.7-19$ & 2 (includes the single piece of impressed baked clay) \\
\cline { 2 - 2 } Total & 22 \\
\hline
\end{tabular}

All baked clay specimens were fired in a low temperature environment as evidence of color change was minimal. With the exception of the impressed specimen, all other examples of baked clay were eroded with sub-rounded edges, suggesting some level of disturbance since their original firing. The impressed specimen has two horizontal impressions, each approximately 1 $\mathrm{mm}$ in width, consistent with various small grass taxa. It is unlikely the impressed baked clay specimen represents daub but rather an incidental grass impression within a clay ground surface.

\section{Fire-Cracked Rock}

Fire-cracked rock (FCR) collected from the testing was first analyzed for material type and then sorted by size. FCR was the most represented artifact class with a total of 348 fragments, ranging in size from less than $6.4 \mathrm{~mm}$ to over $50 \mathrm{~mm}$ (Table 23). The majority of the FCR assemblage from site 41BT427 was limestone ( $n=323,93$ percent); the remaining 15 specimens were of quartzite $(n=7)$, steatite $(n=6)$, and undifferentiated chert $(n=2)$. Test Units 3, 4, 5, 6, 7, 8, and 9 all yielded FCR $(n=298)$. The soil samples from Test Units 5, 7, and 9 additionally produced 50 of the of FCR specimens.

Table 23

41BT427 Fire-Cracked Rock Sorted by Size

Size $(\mathrm{mm})$

Quantity

\begin{tabular}{rc} 
Size $(\mathrm{mm})$ & Quantity \\
$0-6.4$ & 96 \\
$6.4-12.7$ & 114 \\
$12.7-19$ & 63 \\
$19-25.4$ & 25 \\
$25.4-38.1$ & 30 \\
$38.1-50.8$ & 12 \\
$>50.8$ & 8 \\
Total & 348 \\
\hline
\end{tabular}




\section{CHAPTER 6 SUMMARY AND RECOMMENDATIONS}

The test excavation of 41BT427 was designed to collect sufficient data for the evaluation of the eligibility for inclusion in the NRHP and for designation as an SAL as well as its continued research potential. This chapter presents a summary of investigations and recommendations.

\section{ELIGIBILITY CRITERIA}

\section{National Register of Historic Places}

Archeological sites are evaluated according to criteria based on federal regulations for determining the significance of cultural resources for inclusion in the NRHP. Determinations of eligibility for inclusion in the NRHP are applied following the identification of the following criteria, relevant historical themes, and related research questions:

The quality of significance in American history, architecture, archeology, and culture is present in districts, sites, buildings, structures, and objects that possess integrity of location, design, setting, materials, workmanship, feeling, and association, and:

(A) that are associated with events that have made a significant contribution to the broad patterns of our history; or

(B) that are associated with the lives of persons significant in our past; or

(C) that embody the distinctive characteristics of a type, period, or method of construction, or that represent a significant and distinguishable entity whose components may lack individual distinction; or

(D) that have yielded, or may be likely to yield, information important in prehistory or history[36 CFR § 60.4].

Usually, Criterion D is applied to most prehistoric and many historic sites. Important information is generally recognized to as referring to scientific importance. This importance is, of course, driven by such factors as current research perspectives and the state of available information regarding a particular research topic in a specific research area. Over time, data requirements for some research questions may be addressed to various degrees, even though complementary data are often needed from different temporal periods, geographic settings, or site types to fully 
understand the diversity of past human activities. If data approach redundancy, the need for corroborative information from similar sites is diminished. This suggests that information deemed important are tied to both a specific geographical area, reflecting a cultural adaptation or region, and a state of accumulated knowledge regarding a research domain. Archeological sites with integrity containing artifacts and features that can contribute information toward addressing research issues are regarded as significant and are eligible for inclusion in the NRHP.

In many cases, and for various reasons of preservation, site formation processes, or postdepositional disturbances, some archeological remains are generally regarded as having very little or no research potential for contributing useful information toward the understanding of history or prehistory. For instance, an artifact assemblage might be disturbed from its primary context, or components of various temporal periods might be mixed or otherwise not interpretable. In such cases, a site is not regarded as scientifically important, and in general, these kinds of sites are not eligible for inclusion in the NRHP.

\section{State Archeological Landmark}

At the state level, archeological sites may be considered significant and be recognized or designated as an SAL, provided that at least one of the following conditions is met:

1. The archeological site is situated on lands owned or controlled by the State of Texas or one of its political subdivisions; or

2. The archeological site is situated on private land which has been specifically designated as an SAL $\ldots$ and fits at least one of the following criteria:

(A) Preservation of materials must be sufficient to allow application of standard archeological techniques to advantage;

(B) The majority of artifacts are in place so that a significant portion of the site's original characteristics can be defined through investigation;

(C) The site has the potential to contribute to cumulative culture history by the addition of new information;

(D) The site offers evidence of unique or rare attributes; and/or

(E) The site offers a unique and rare opportunity to test techniques, theory, or methods or preservation, thereby contributing to scientific knowledge [Texas Natural Resources Code 1977; Title 9, Chapter 191, Texas Antiquities Committee, Section 191.094 and Chapter 41.7, Antiquities Code of Texas].

\section{SUMMARY}

During the current project by Geo-Marine, the bridge replacement area was investigated via backhoe trenches and test units. Thirteen trenches were dug within the project area: nine survey trenches in the northwest, southwest, and southeast quadrants outside the known boundary of site 41BT427, and four trenches within the site itself in the northeast quadrant. The current investigation within site 41BT427 involved the mechanical excavation of the four trenches $(29.5$ linear meters) and the hand excavation of eight test units (8.94 cubic meters) within the site boundary (an additional test unit was excavated south of the site boundary). Only one definable cultural component (Feature 1) was identified at site 41BT427. The single feature identified consisted of a very small, disarticulated cluster of six burned rocks and included 56 chipped stone flakes and seven bone fragments. No diagnostic material was recovered during excavation. 
Backhoe trenching in the northwest, southwest, and southeast quadrants outside the known boundary of site 41BT427 did not reveal any cultural material. Test excavations within site 41BT427 provided sparse data concerning Central Texas prehistoric subsistence, seasonality, chronology and site specific activities. Limited faunal and botanical evidence suggest site inhabitants were targeting terrestrial food sources such as deer and pecan as well aquatic taxa like mussels and fish. The riparian setting of 41BT427 was likely inhabited during the fall season when deer and pecan would have been most plentiful but due to the paucity of data, site usage in other seasons cannot be discounted. All lithic material recovered from test excavations appear to be Edwards Plateau chert with no discernable evidence of imported chipped stone resources. The AMS data from the site's only feature (Feature 1) and associated strata both suggest the sites primary usage dates to the transitional Late Archaic - Late Prehistoric period. No other definitive culturally diagnostic material was recovered from the test excavations. Site activities such as tool maintenance, animal carcass processing and cooking can be tentatively inferred from the recovered lithic, faunal, and FCR evidence.

\section{RECOMMENDATIONS}

Testing (i.e. backhoe trenching and one test unit) outside of the site boundary for 41BT427 within the northwest, southwest, and southeast quadrants of the project area failed to detect any cultural material and no further work in these areas is recommended.

Although site 41BT427 does provide some very basic information concerning subsistence, seasonality, mobility, chronology, and site-specific activities, the data as such do not appreciably add to our understanding Central Texas prehistory. The sparse evidence provided by the lowdensity deposits of site 41BT427 indicates the site has little potential to add further to our understanding of Central Texas prehistory. Thus, site 41BT427 fails to meet the standards of Criterion D or any other significant standard for assessing NRHP or SAL eligibility. Site 41BT427 is recommended as not eligible for NRHP inclusion or for designation as an SAL. No historic properties as defined under 36 CFR 60.4, 13 TAC 26.5(6), 13 TAC 26.5(32), and 13 TAC 26.8 were identified during the archeological investigation of the current project APE. In accordance with 36 CFR 800.4(d)(2) and 13 TAC 26.2, no further investigation is necessary at site 41BT427. 



\section{REFERENCES CITED}

Baugh, T., and S. Perkins (eds.)

2008 Land of Our Ancestors: Studies in Protohistoric and Historic Wichita Cultures. Memoirs of the Plains Anthropological Society. Oklahoma Archaeological Survey, Norman.

Beaty, Harold E.

1978 A Checklist of Flora and Fauna, Central and West Bell County, Texas. Manuscript on file, Life Sciences Library, University of Texas at Austin.

Boyd, D. K

1997 Late Prehistoric II (A.D. 1100/1200-1541) and Protohistoric (A.D. 1541-1750) Periods. In Caprock Canyonlands Archeology: A Synthesis of the Late Prehistory and History of Lake Alan Henry and the Caprock Escarpment, edited by D. K. Boyd, S. A. Tomka, and M. D. Freeman, pp. 337-486. Vol. II. Reports of Investigations No. 110. Prewitt and Associates, Inc., Austin.

Black, S. L.

1989 Central Texas Plateau Prairie. In From the Gulf to the Rio Grande: Human Adaptation in Central, South, and Lower Pecos Texas, by T. R. Hester, S. L. Black, D. G. Steele, B. W. Olive, A. A. Fox, K. J. Reinhard, and L. C. Bement, pp. 17-38. Research Series No. 33. Arkansas Archaeological Survey, Fayetteville.

Bowden, G. B.

1940 History of Burnet County. Master's thesis, University of Texas at Austin.

Bryant, John A.

1985 Seed Physiology. Studies in Biology No. 165. The Institute of Biology. Edward Arnold, Ltd., London. 
Bryant, V. M., Jr., and R. G. Holloway

1985 A Late Quaternary Paleoenvironmental Record of Texas: An Overview of the Pollen Evidence. In Pollen Records of Late Quaternary North American Sediments, edited by Bryant, V. M., Jr., and R. G. Holloway, pp. 39-70. American Association of Stratigraphic Palynologist Foundation, Dallas.

Burt, W. H., and R. P. Grossenheider

1976 Peterson Field Guides: Mammals. Houghton Mifflin Company, Boston and New York.

Bush, Leslie L.

2009 Plant Remains from Three Burned Rock Middens at Fort Hood, Coryell County, Texas. Report submitted to Prewitt and Associates, Inc., Austin, Texas.

2010 Preliminary Report on a Flotation Sample from Eagle Bluff (41ME147): Medina County, Texas. Report submitted to Texas Archeological Society, San Antonio, Texas.

Castañeda, P. R.

1554[1904] The Journey of Coronado. Translated and edited by G. P. Winship. A. S. Barnes \& Co., New York.

Collins, M. B.

1994 Evidence of Early Archaic Occupation. In Archaic and Late Prehistoric Human Ecology $n$ the Middle Onion Creek Valley, Hays County, Texas, by R. A. Ricklis and M. B. Collins, pp. 67-100. Vol 1. Studies in Archaeology 19. Texas Archaeological Research Laboratory, University of Texas at Austin.

1995 Forty Years of Archaeology in Central Texas. Bulletin of the Texas Archaeological Society 66:361-400.

- 1998 Clovis and Folsom Lithic Technology on or Near the Southern Plains: Similar Ends, Different Means. In Folsom Lithic Technology: Explorations in Structure and Variation, edited by D. S. Amick, pp. 12-38. Archaeological Series 12. International Monographs in Prehistory. Ann Arbor, Michigan.

2004 Archeology in Central Texas. In The Prehistory of Texas, edited by T. Perttula, pp. 101-151. Texas A\&M University Press, College Station.

Collins, M. B., G. L. Evans, T. N. Campbell, M. C. Winans, and C. E. Mear

1989 Clovis Occupations at Kincaid Shelter, Texas. Current Research in the Pleistocene $6: 3-4$.

Core, H. A., W. A. Cote, and A. C. Day

1979 Wood Structure and Identification. 2nd ed. Syracuse University Press, Syracuse, New York.

Correll, Donovan Stewart, and Marshall Conring Johnston

1970 Manual of the Vascular Plants of Texas. Texas Research Foundation, Renner, Texas. 
Davis, Linda W.

1993 Weed Seeds of the Great Plains: A Handbook for Identification. University Press of Kansas, Lawrence.

Diggs Jr., George M., Barney L. Lipscomb, and Robert J. O'Kennon

1999 Shinners and Mahler's Illustrated Flora of North Central Texas. Second Printing, 2000, with minor corrections. Illustrated Texas Floras Project. Botanical Research Institute of Texas, Fort Worth.

Dillehay, T. D.

1974 Late Quaternary Bison Population Changes on the Southern Plains. Plains Anthropologist 19(65):180-196.

Fonteyn, Paul J., M. Wade Stone, Malinda A. Yancy, John T. Baccus, and Nalini M. Nadkarni

1988 Determination of Community Structure by Fire. In Edwards Plateau Vegetation: Plant Ecological Studies in Central Texas, edited by Bonnie B. Amos and Frederick R. Gehlbach. Baylor University Press, Waco, Texas.

Freeman, M. D., and D. K. Boyd

1997 Historic Sites Investigations at Lake Alan Henry and in the Texas Panhandle-Plains. In Caprock Canyonlands Archeology: A Synthesis of the Late Prehistory and History of Lake Alan Henry and the Caprock Escarpment, edited by D. K. Boyd, S. A. Tomka, and M. D. Freeman, pp. 65-98. Vol. I. Reports of Investigations No. 110. Prewitt and Associates, Inc., Austin.

Graham, R. W.

1987 Late Quaternary Fauna and Paleoenvironments of the Southwestern Plains of the United States. In Late Quaternary Mammalian Biogeography and Environments of the Great Plains and Prairies, edited by R. W. Graham, H. A. Smecken Jr., and M. A. Graham, pp. 24-86. Scientific Papers Volume 22. Illinois State Museum, Springfield.

Gould, Frank W.

1962 Texas Plants-A Checklist and Ecological Summary. The Agricultural and Mechanical College of Texas, Texas Agricultural Experiment Station, College Station, Texas.

Hall, Grant D.

2000 Pecan Food Potential in Prehistoric North America. Economic Botany 54(1):103112.

Hall, S. A., and S. Valastro Jr.

1995 Grassland Vegetation in the Southern Great Plains during the Last Glacial Maximum. Quaternary Research 44:237-245.

Hoadley, R. Bruce

1990 Identifying Wood: Accurate Results with Simple Tools. Taunton Press, Newtown, Connecticut. 
Johnson, E. H.

2001 "Lampasas Cut Plain." Handbook of Texas Online http://www.tsha.utexas.edu/ handbook/online/articles/GG/rxg2.html (accessed November 5, 2007).

Johnson, L

1994 The Life and Times of Toyah-Culture Folk as Seen from the Buckhollow Encampment, Site 41 KM16 of Kimble County Texas. Office of the State Archaeologist Report 38. Texas Department of Transportation and the Texas Historical Commission, Austin.

Johnson, L., and G. Goode

1994 A New Try at Dating and Characterizing Holocene Climates, as Well as Archaeological Periods, on the Eastern Edwards Plateau. Bulletin of the Texas Archaeological Society 65:1-51.

Keepax, Carole

1977 Contamination of archaeological deposits by seeds of modern origin with particular reference to the use of flotation machines. Journal of Archaeological Science 4:221229.

Kutac, E. A., and S. C. Caran

1994 Birds and Other Wildlife of South Central Texas. University of Texas Press, Austin.

Lipscomb, C. A.

2008 "Comanche Indians." The Handbook of Texas Online. http://www.tshaonline.org/ handbook/online/ articles/CC/bmc72.html (accessed 16 December 2008).

Lopinot, Neal H., and David Eric Brussell

1982 Assessing Uncarbonized Seeds from Open-air Sites in Mesic Environments: An Example from Southern Illinois. Journal of Archaeological Science 9:95-108.

Martin, Alexander C., and William D. Barkley

1961 Seed Identification Manual. University of California Press, Berkeley.

Masson, M. A., and M. B. Collins

1995 The Wilson-Leonard Site (41WM235). Cultural Resource Management News and Views 7(1):6-10. Forty Years of Archaeology in Central Texas. Bulletin of the Texas Archaeological Society 66: 361-400.

Mehalchick, Gemma, Douglas K. Boyd, Karl W. Kibler, and Christopher W. Ringstaff

2004 Shifting Sands and Geophytes: Geoarcheological Investigations at Paluxy Sites on Fort Hood, Texas. Research Report No. 48. United States Army Fort Hood Archeological Resource Management Series.

Miksicek, Charles H.

1987 Formation Processes of the Archaeobotanical Record. In Advances in Archaeological Method and Theory, vol. 10, edited by Michael B. Schiffer, pp. 211247. Academic Press, Inc. 
Moerman, Daniel E.

1998 Native American Ethnobotany. Timber Press, Portland, Oregon.

Musil, Albina F.

1963 Identification of Crop and Weed Seeds. Agriculture Handbook No. 219. U.S. Department of Agriculture, Washington, D.C.

Nichols, M. L., and B. W. Farabough

2007 Interim Report for Archeological Survey: FM 963 at North Rocky Creek. Submitted to TxDOT ENV.

Panshin, A. J., and Carol de Zeeuw

1980 Textbook of Wood Technology: Structure, Identification, Properties, and Uses of the Commercial Woods of the United States and Canada. 4th ed. McGraw-Hill, New York.

Pearsall, Deborah M.

2000 Paleoethnobotany: A Handbook of Procedures. 2nd ed. Academic Press, San Diego.

Posada, A. de

1686[1982] Alonso de Posada Report, 1686 (Situación de Quivira y Teguayo Provincias Cercanos de Nuevo Mexico). Edited and translated by A. B. Thomas. Perdido Bay Press, Pensacola.

Ricklis, R. A.

1994 Toyah Components: Evidence for Occupations in the Project Area During the Later Part of the Late Prehistoric Period. In Archaic and Late Prehistoric Human Ecology $n$ the Middle Onion Creek Valley, Hays County, Texas, vol. 1, by R. A. Ricklis and M. B. Collins, pp. 207-316. Studies in Archaeology 19. Texas Archaeological Research Laboratory, University of Texas at Austin.

Riskind, David H., and David D. Diamond

1988 An Introduction to Environments and Vegetation. In Edwards Plateau Vegetation: Plant Ecological Studies in Central Texas, edited by Bonnie B. Amos and Frederick R. Gehlbach, pp. 1-15. Baylor University Press, Waco, Texas.

Roberts, A., and J. E. Bradford

1997 Speaking Nation to Nation: A Common Cause on Common Ground. Common Ground 2(3/4). Available at http://www.nps.gov/archeology/CG/vol2_num34/common.htm, accessed 11 April 2010.

Toomey, R. S., III, M. D. Blum, and S. Valastro Jr.

1993 Late Quaternary Climates and Environments of the Edwards Plateau, Texas. Global and Planetary Change 7:299-320.

Tull, Delena

1999 Edible and Useful Plants of Texas and the Southwest. University of Texas Press, Austin. 
U.S. Department of Agriculture, Agricultural Research Service

2009 USDA National Nutrient Database for Standard Reference. Release 22. Accessed $2 / 23 / 10$.

U.S. Department of Agriculture, Natural Resources Conservation Service (USDA, NRCS)

2010a Online Web Soil Survey, http://websoilsurvey.nrcs.usda.gov/app/ (accessed April 1, 2010).

2010b The PLANTS Database, http://plants.usda.gov/ (accessed 2/3/10).

Wang, Yang, A. Hope Jahren, and Ronald Amundson

1997 Potential for ${ }^{14} \mathrm{C}$ Dating of Biogenic Carbonate in Hackberry (Celtis) Endocarps. Quaternary Research 47:337-343.

Yanovsky, E., E. K. Nelson, and R. M. Kingsbury

1932 Berries Rich in Calcium. Science 75(1952):565-566. 
APPENDIX A

\section{ARTIFACT ANALYSES DATA}





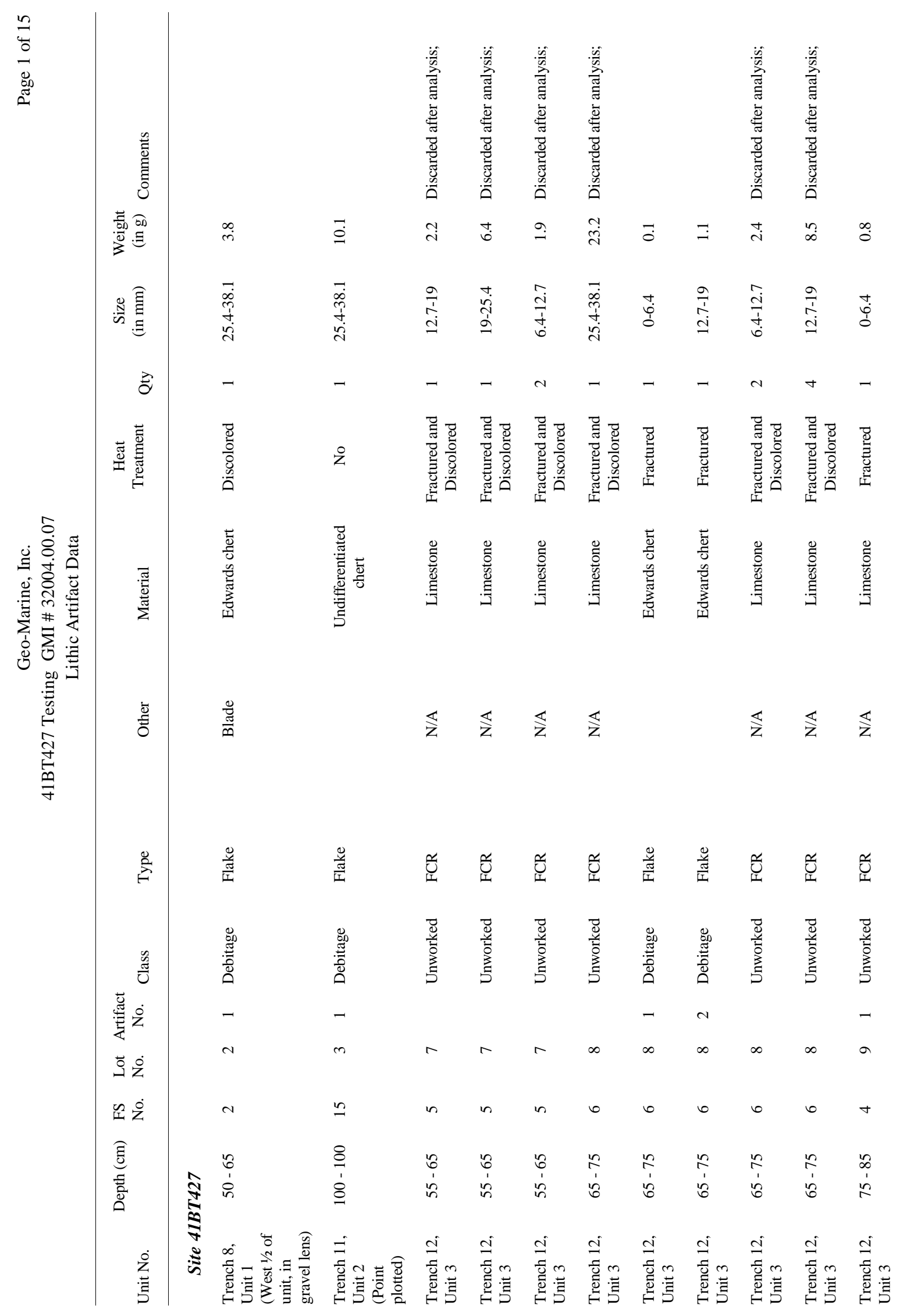




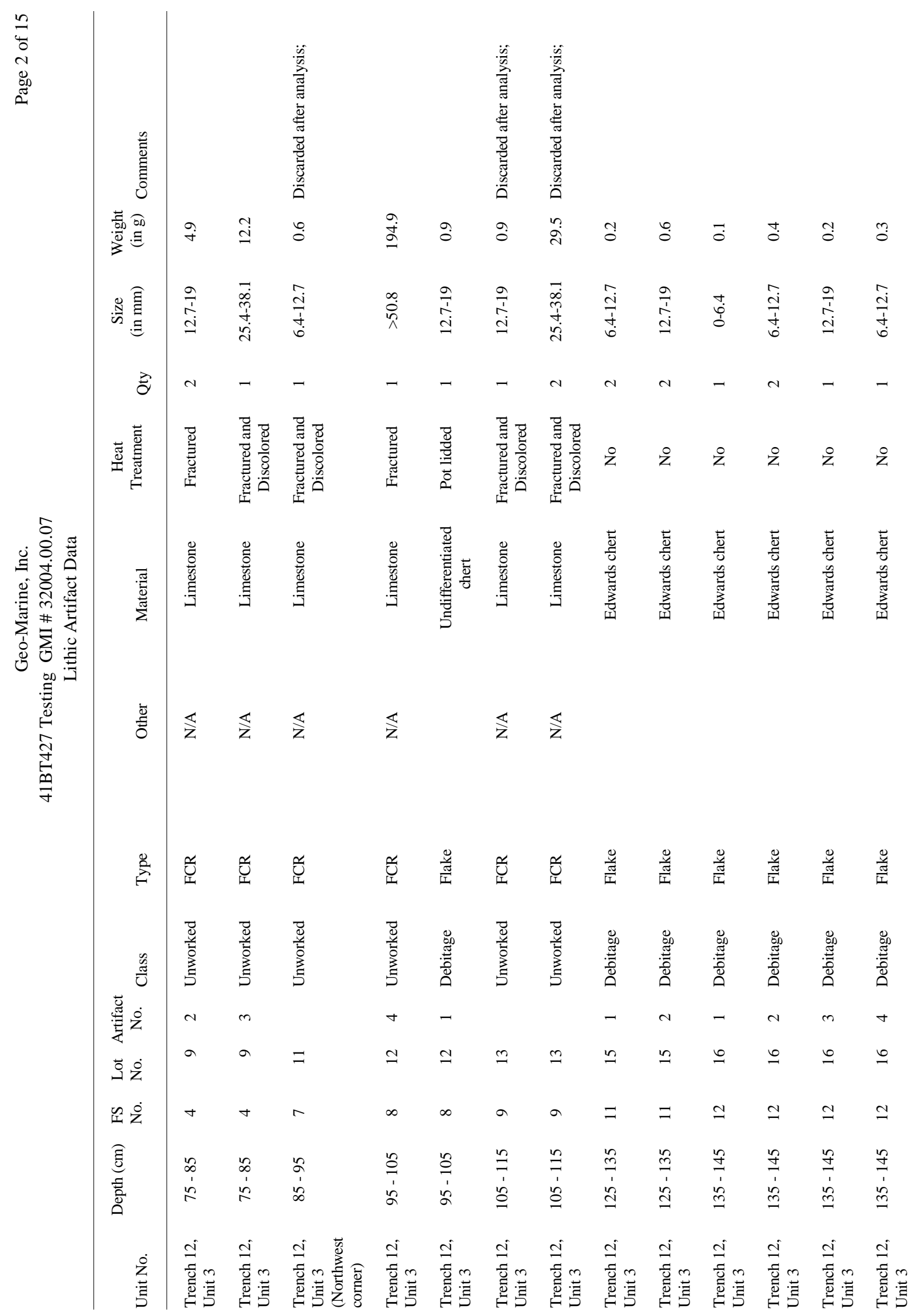




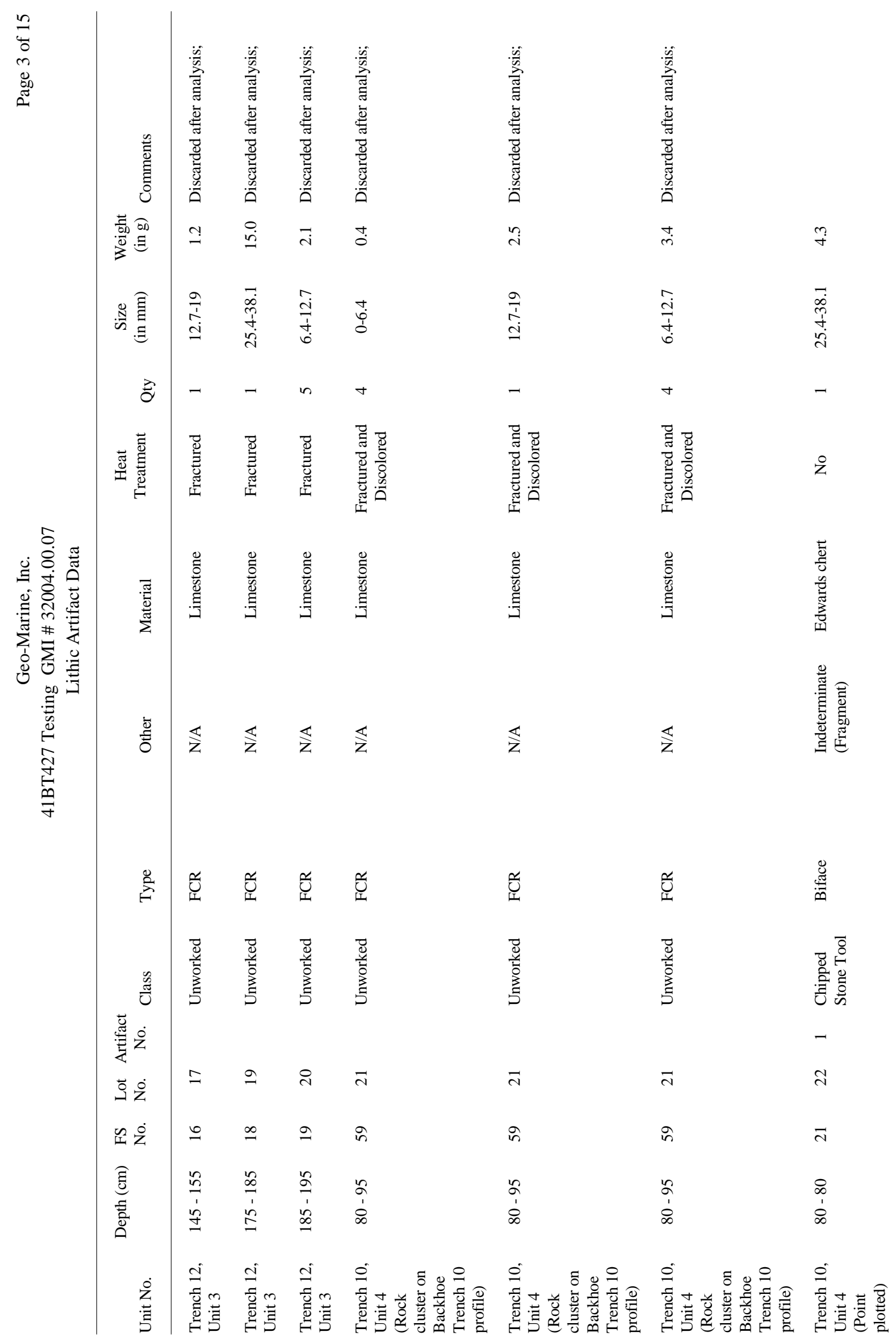




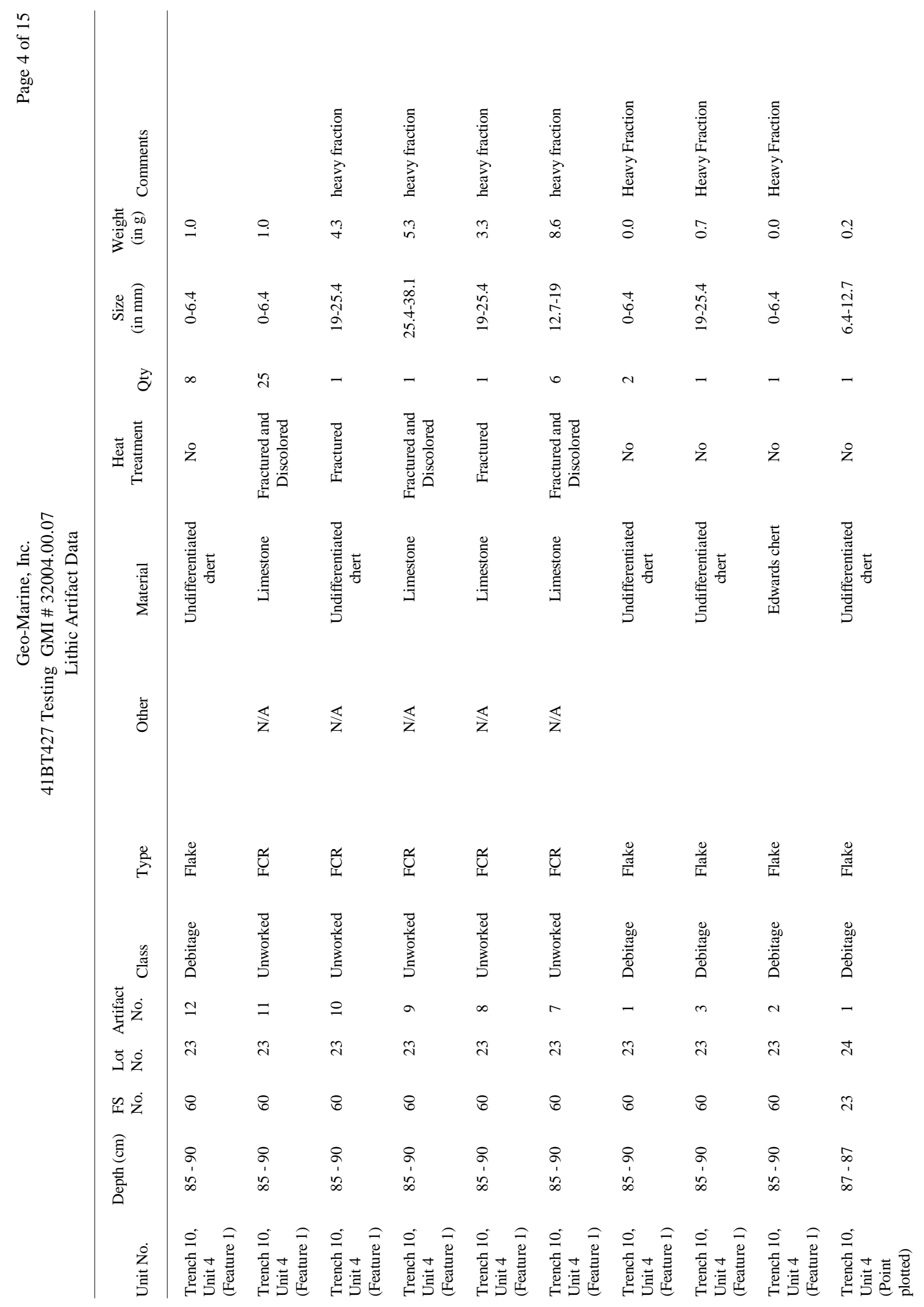




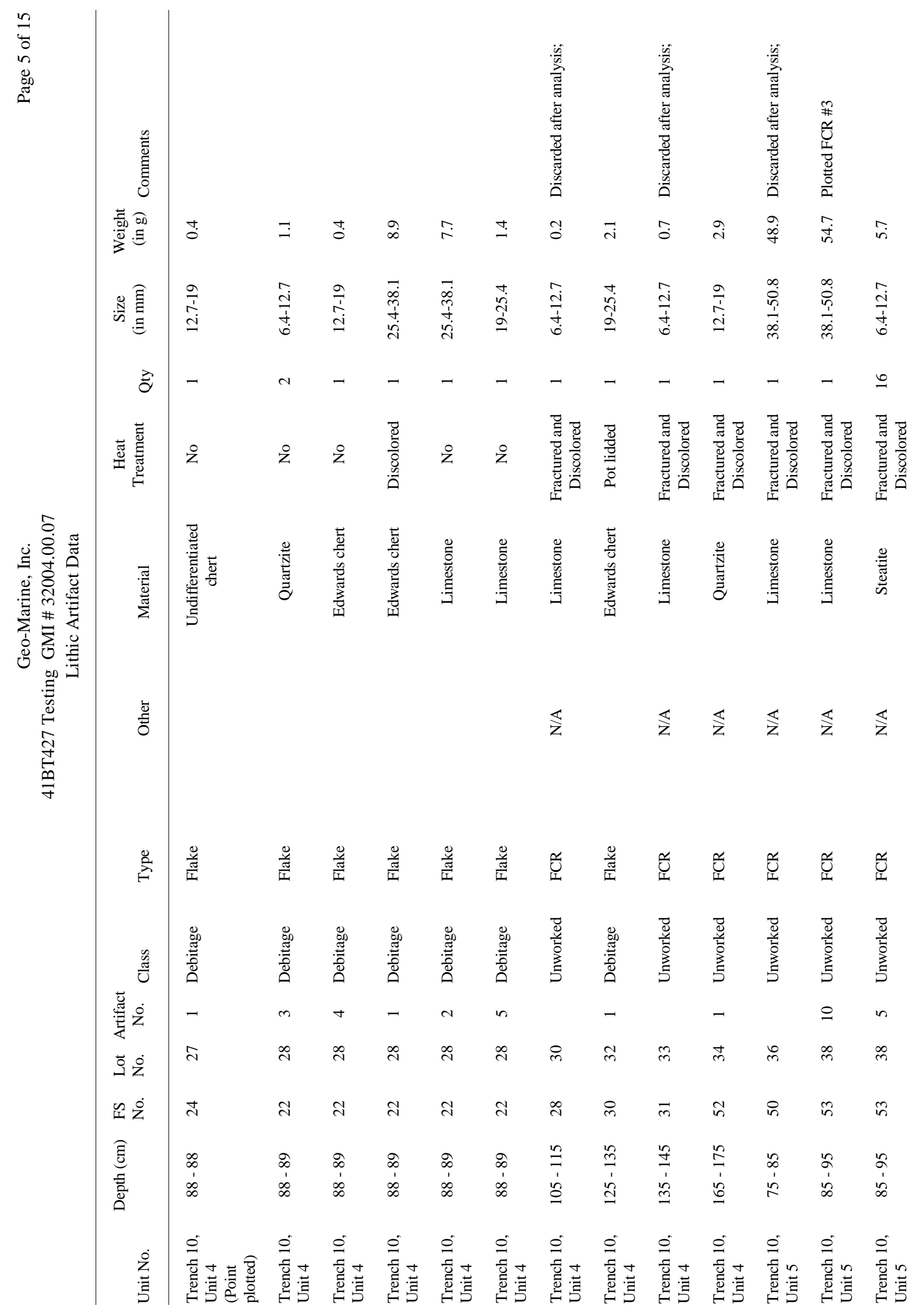




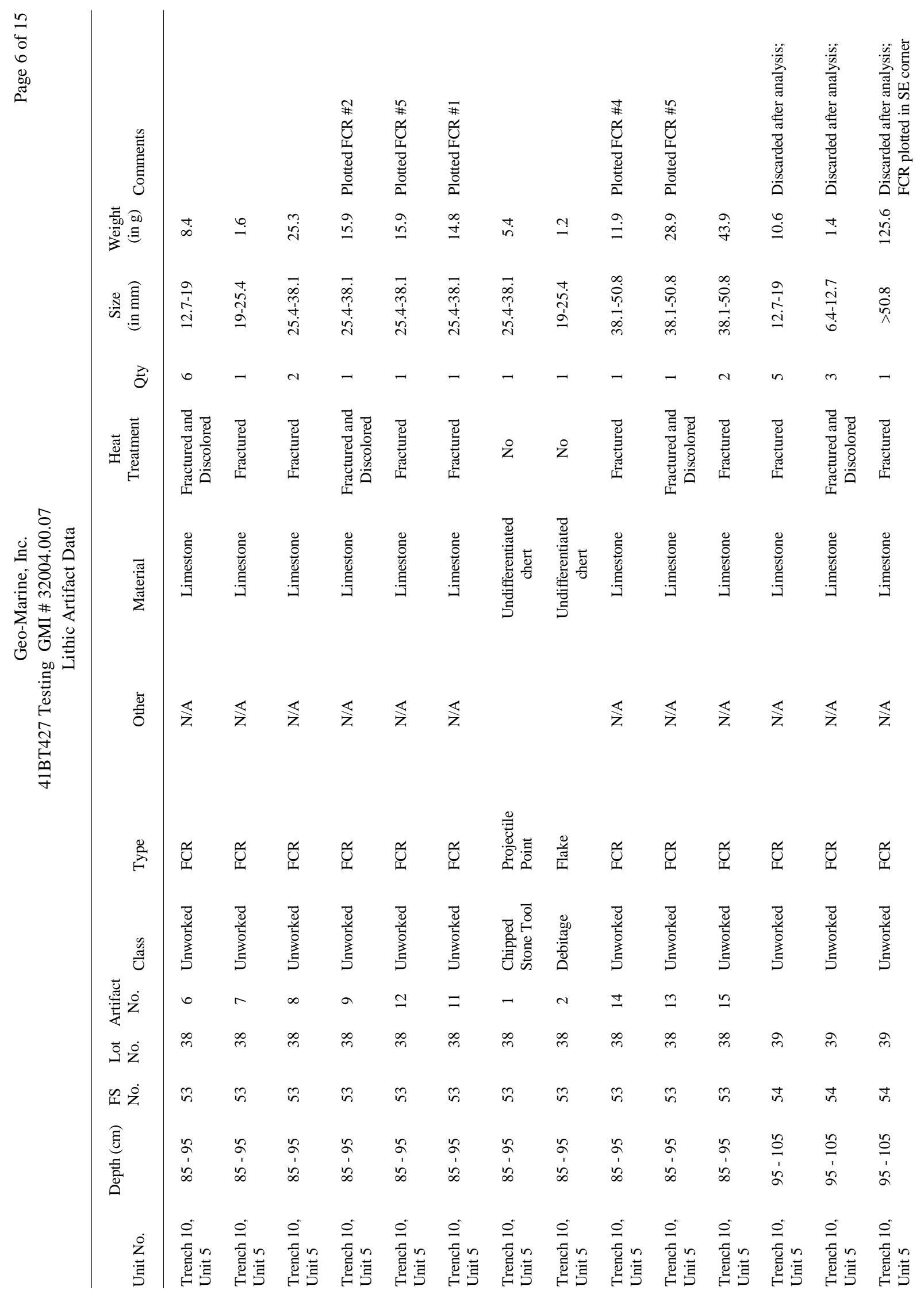




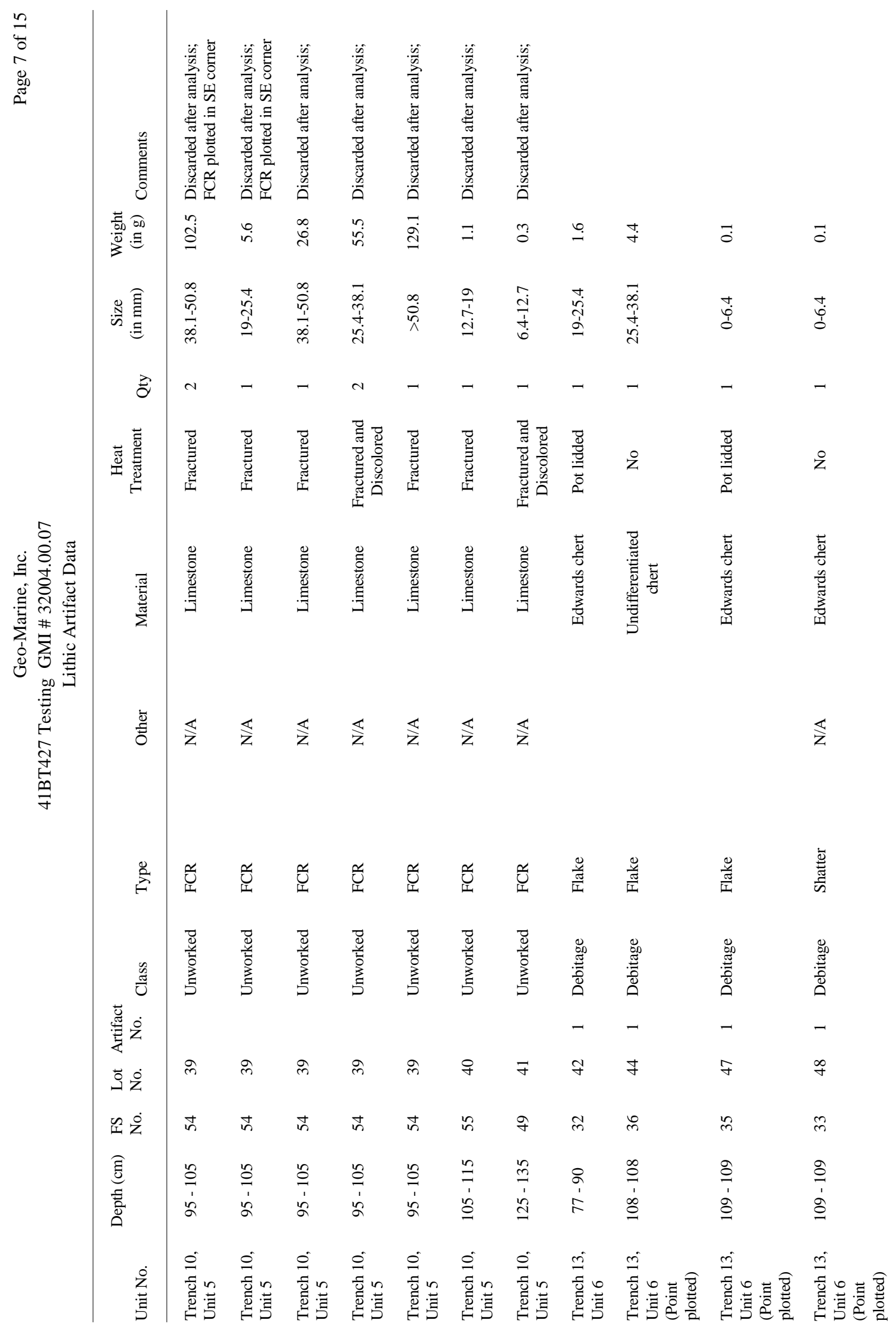




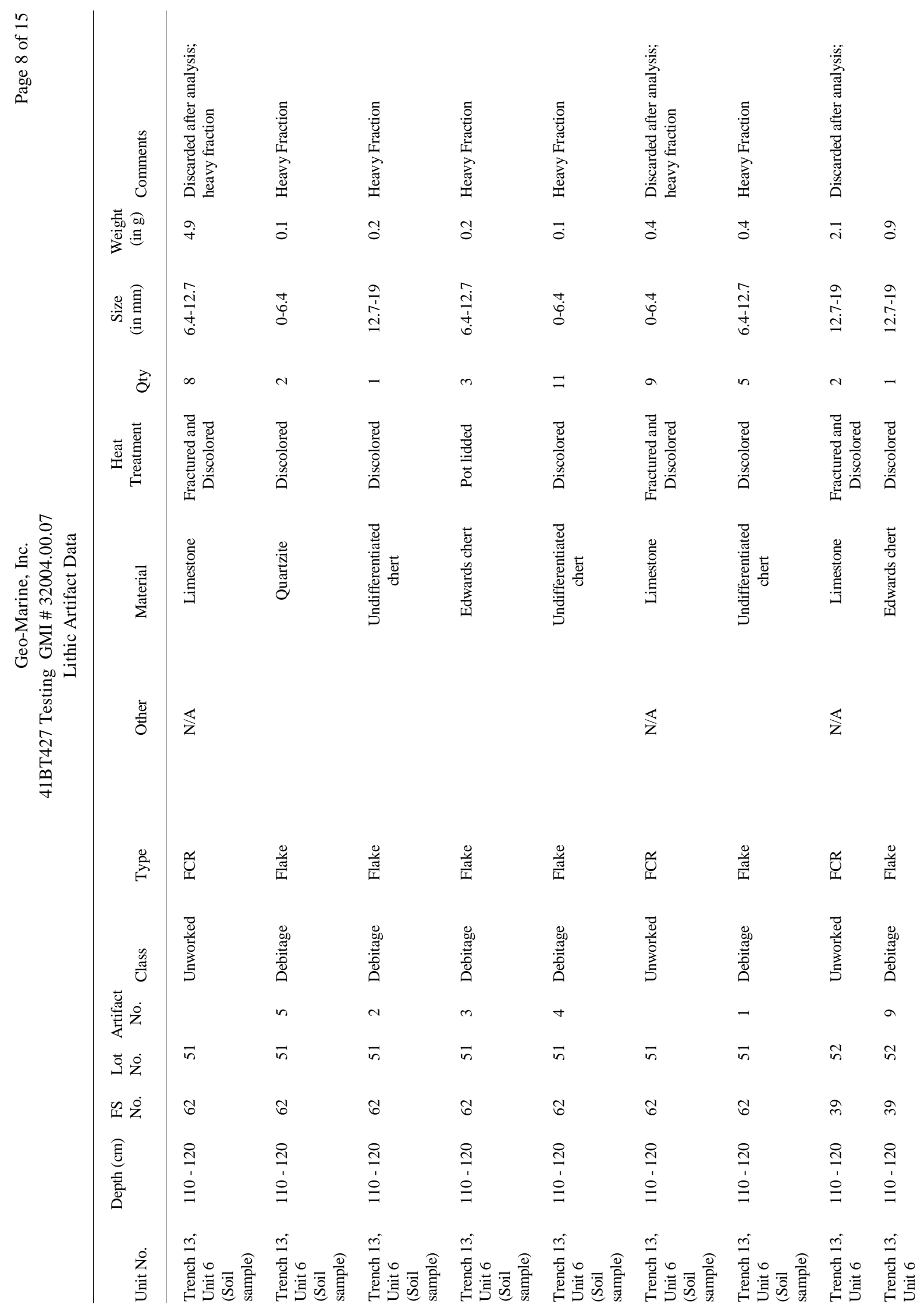




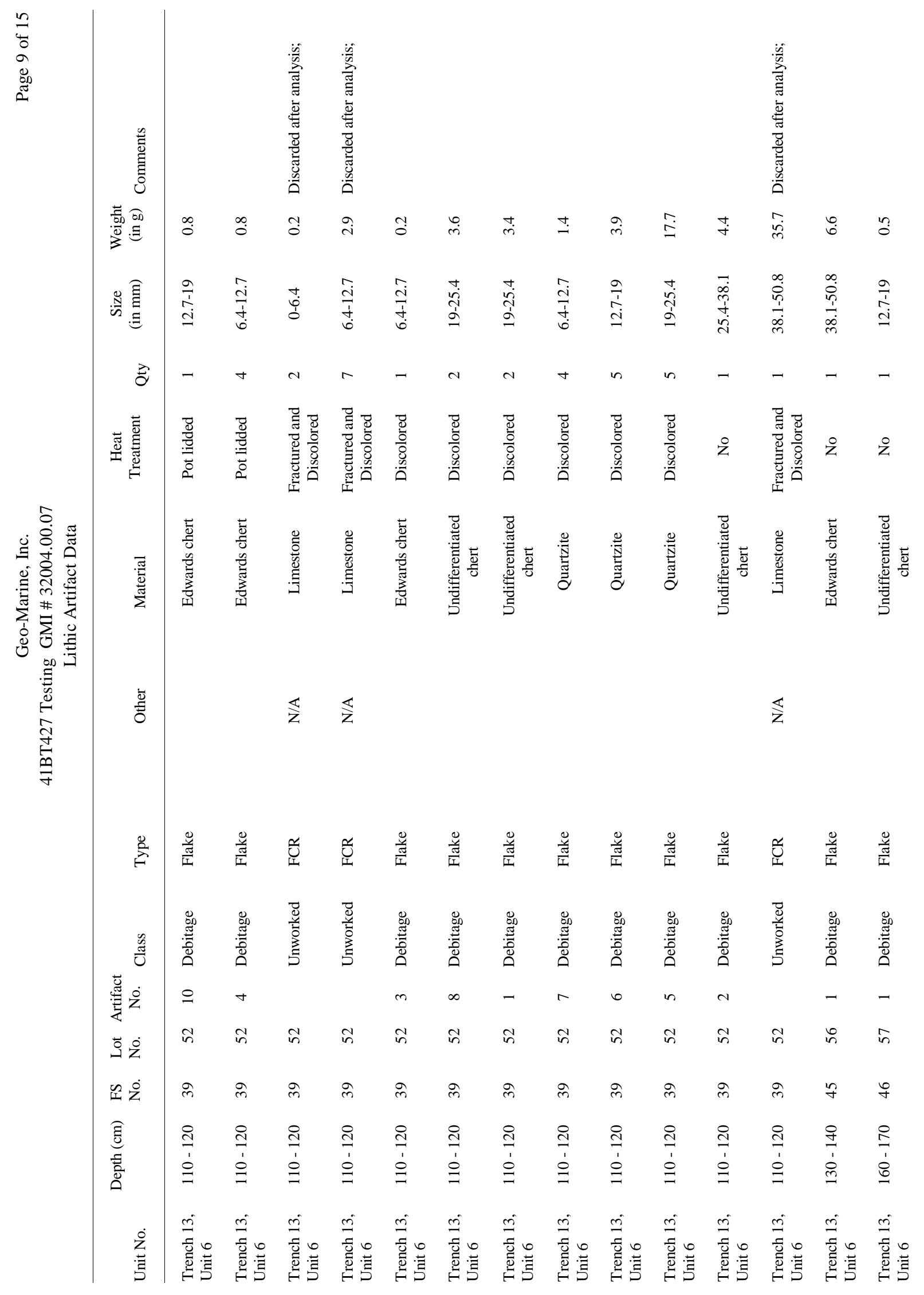




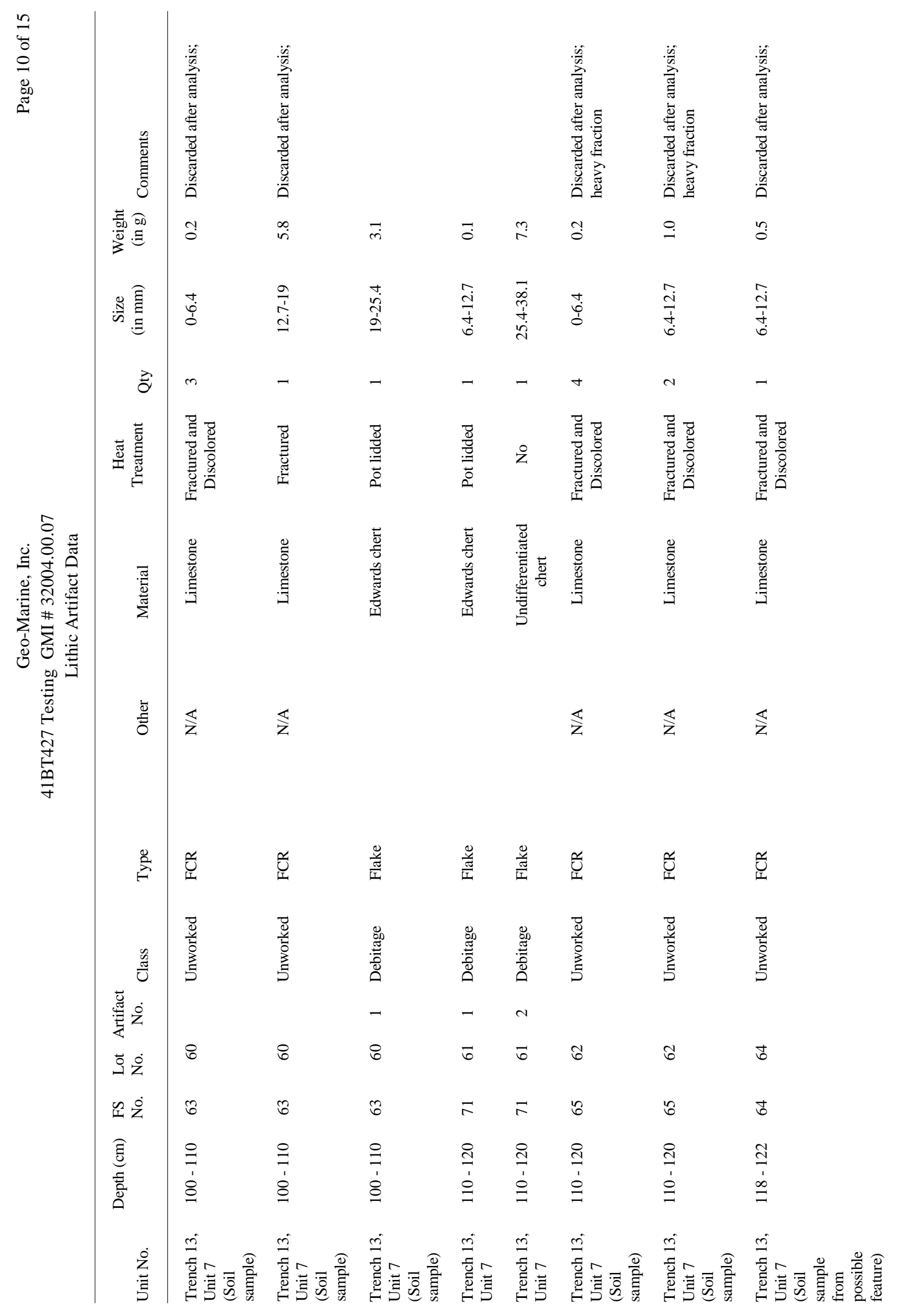




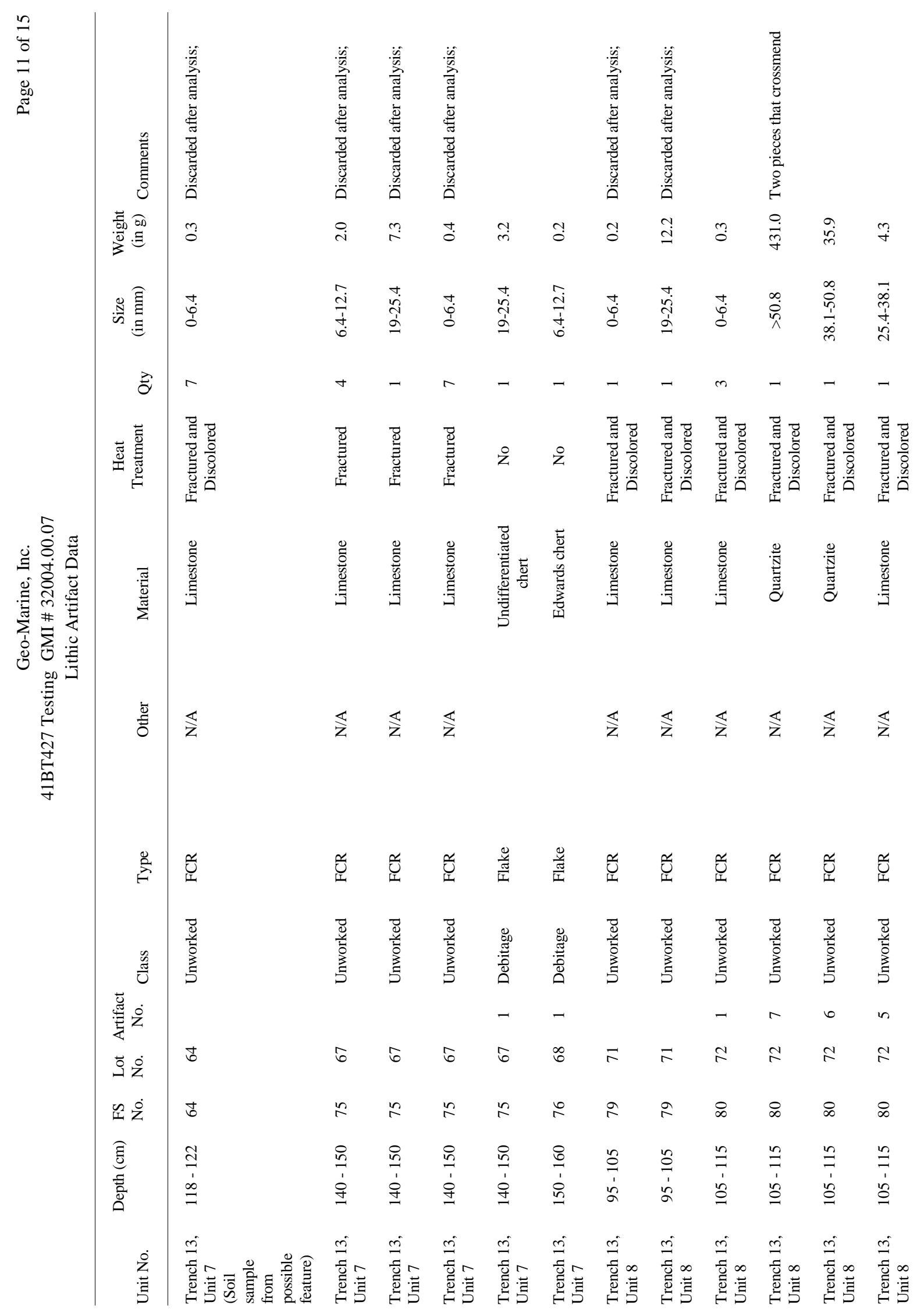




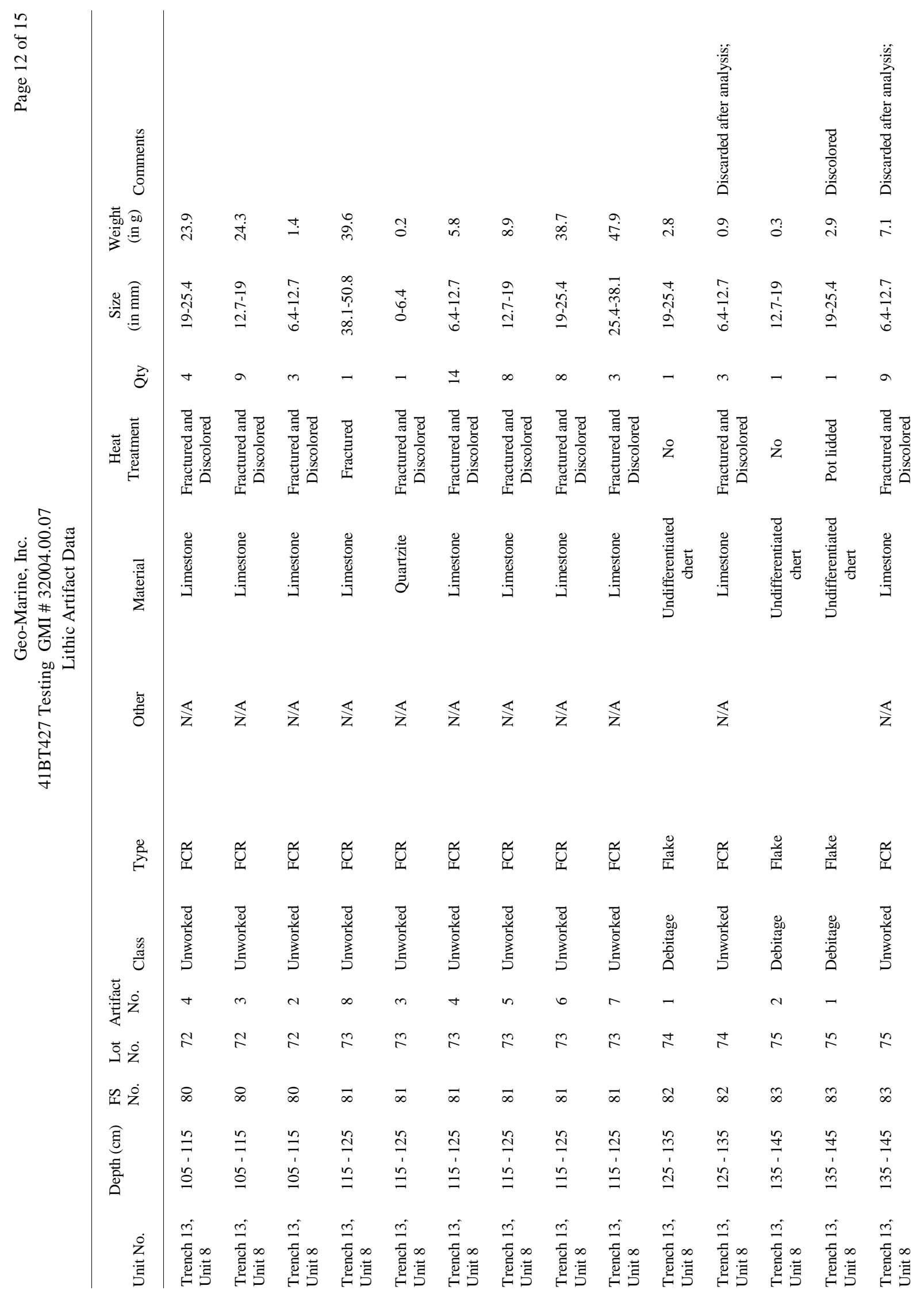




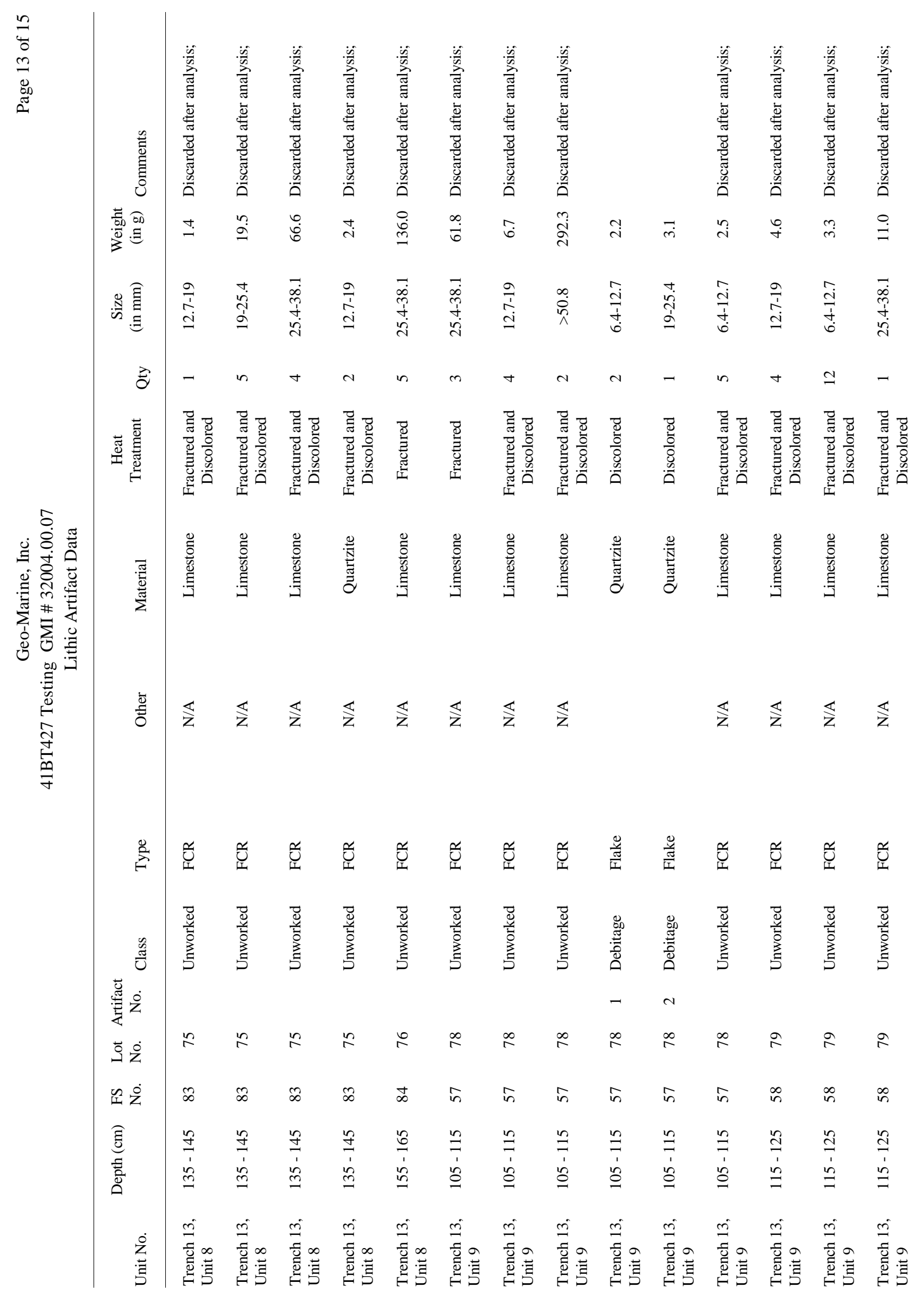




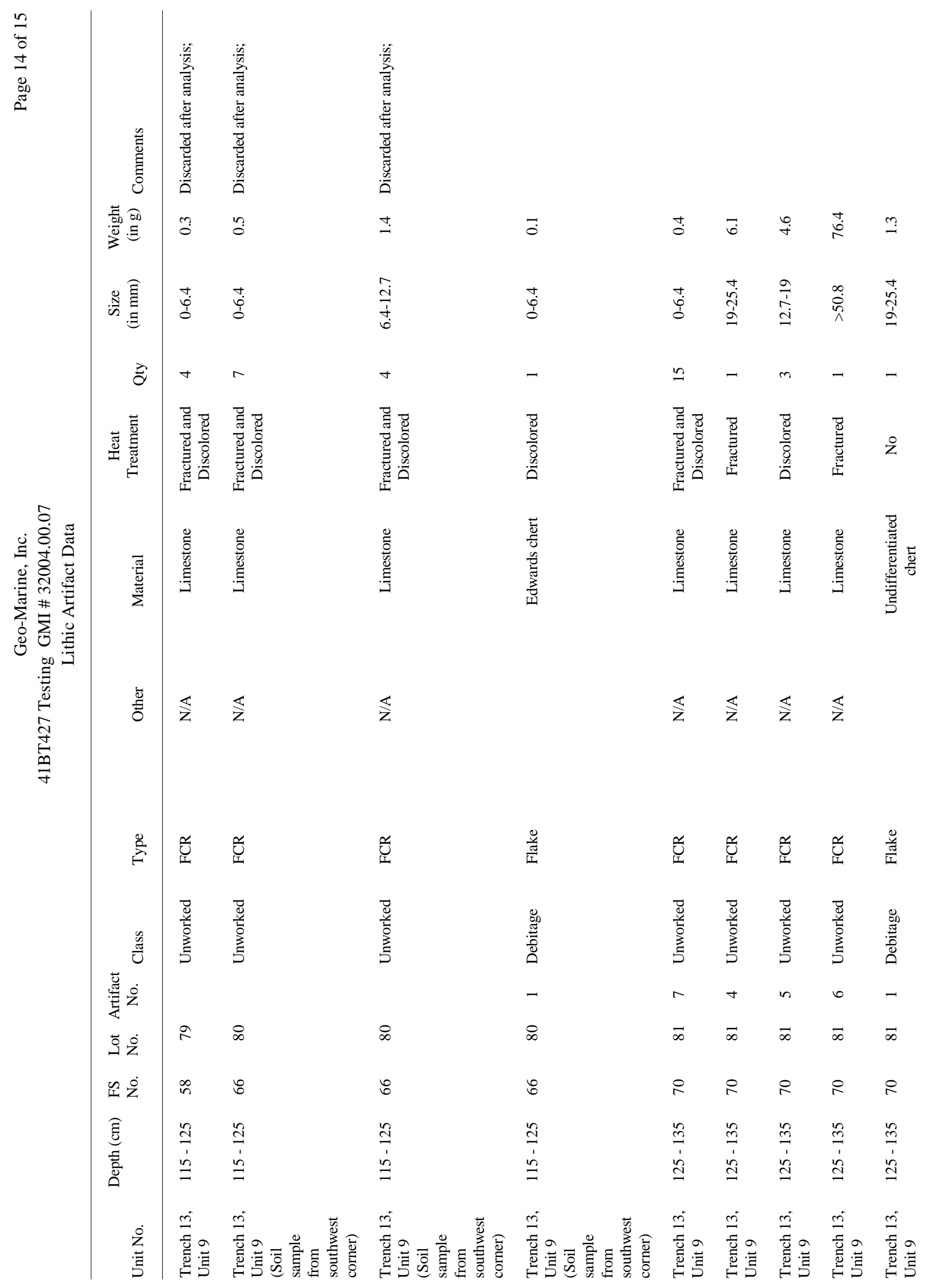




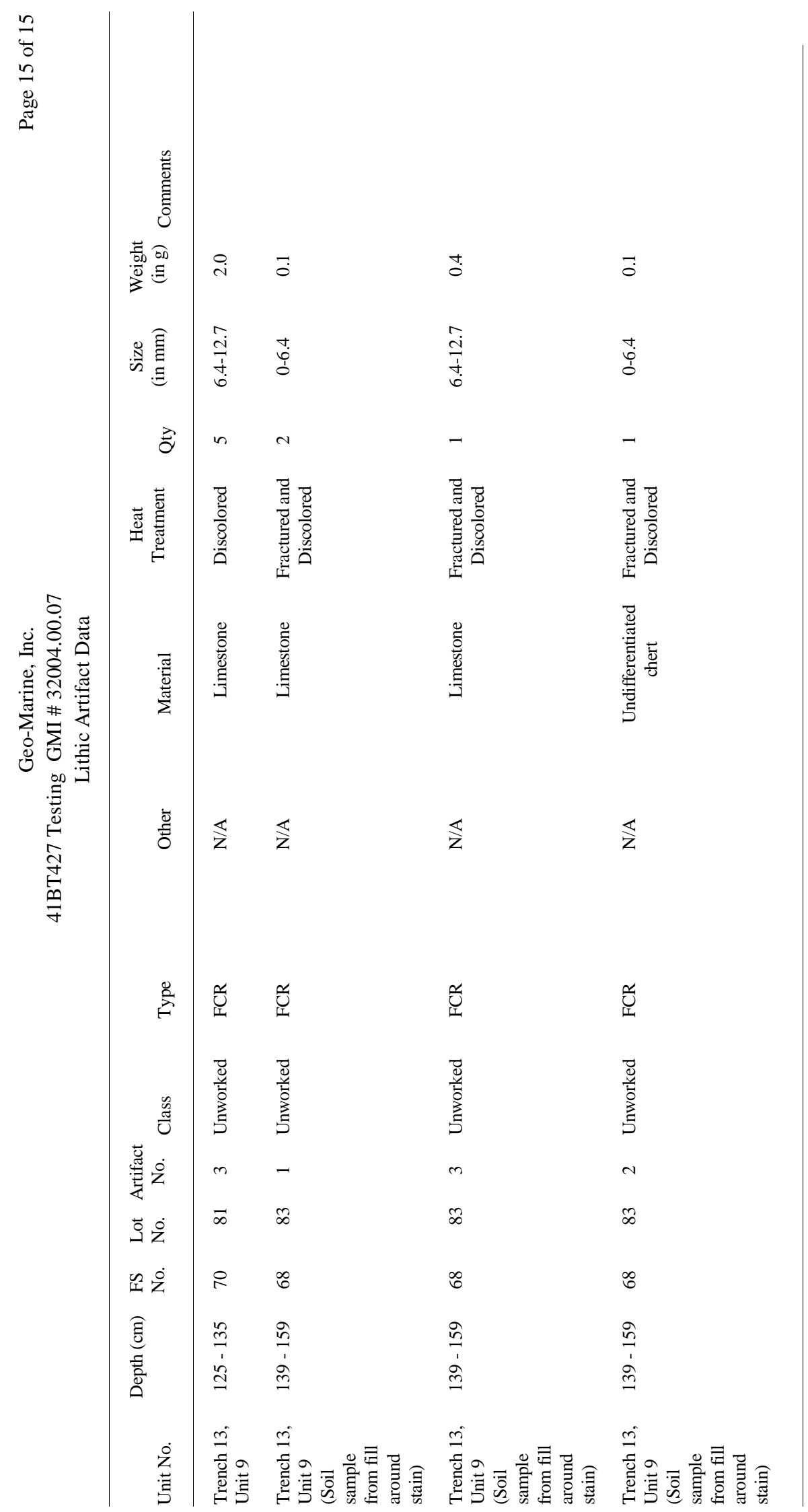





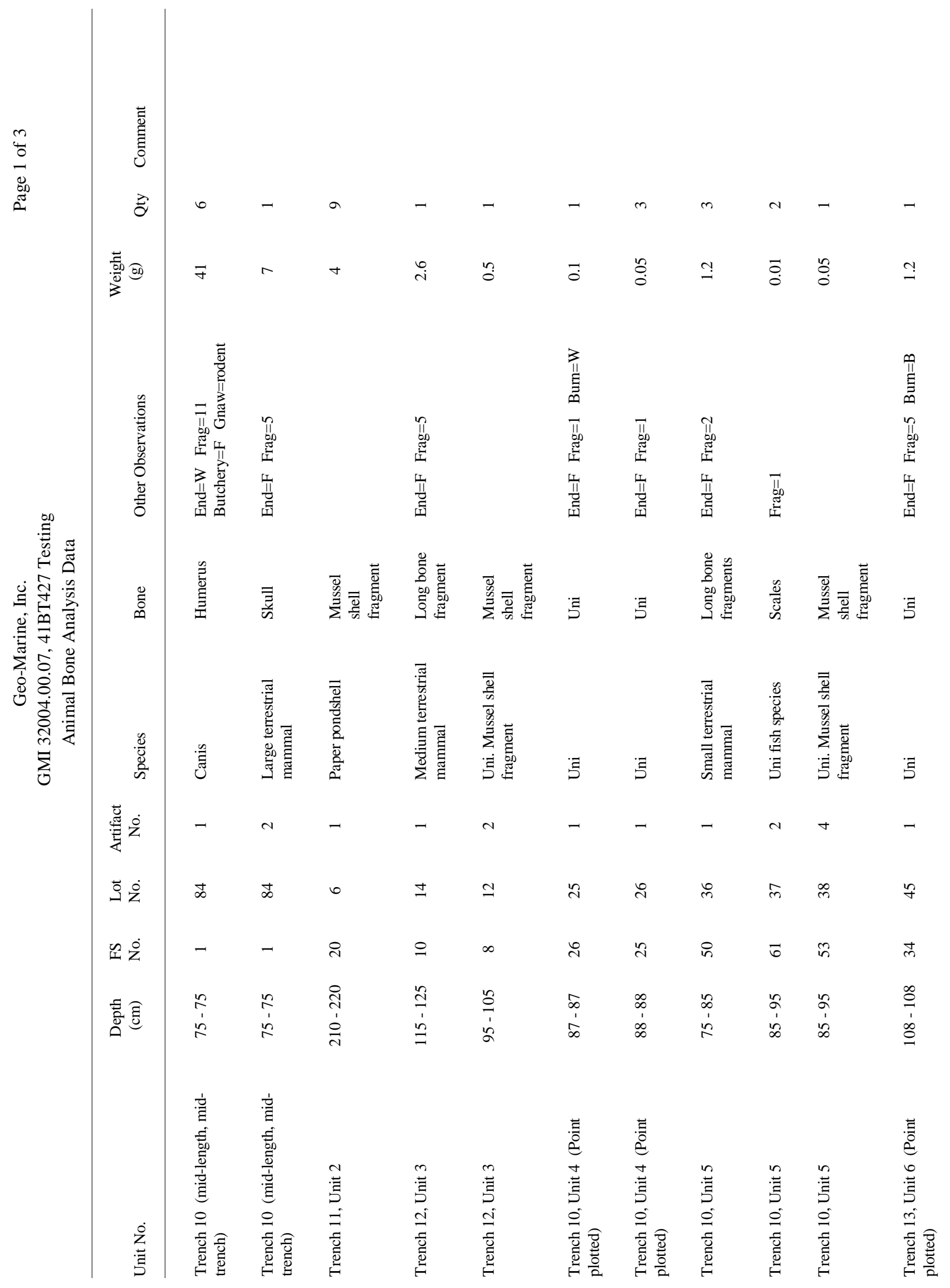




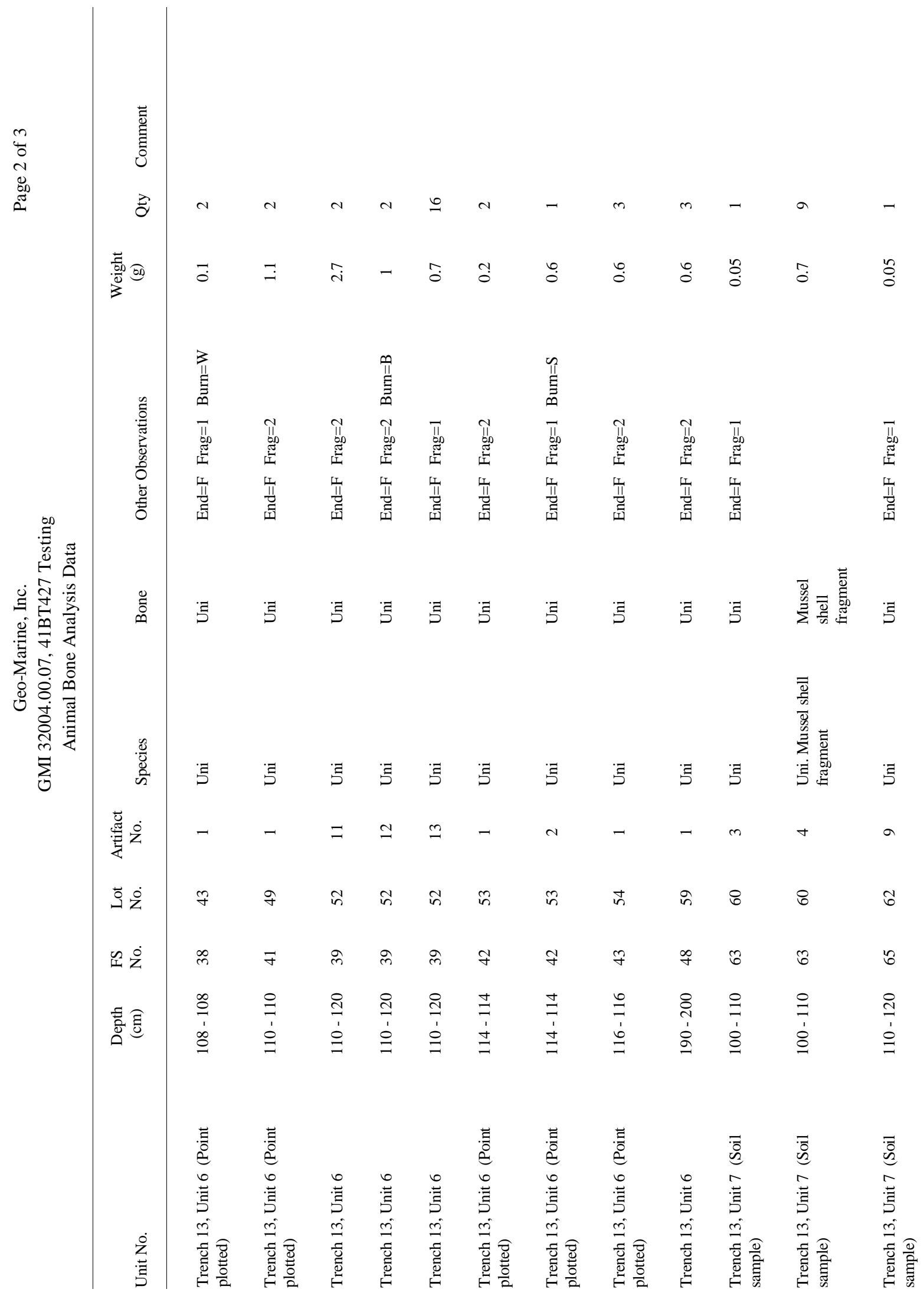




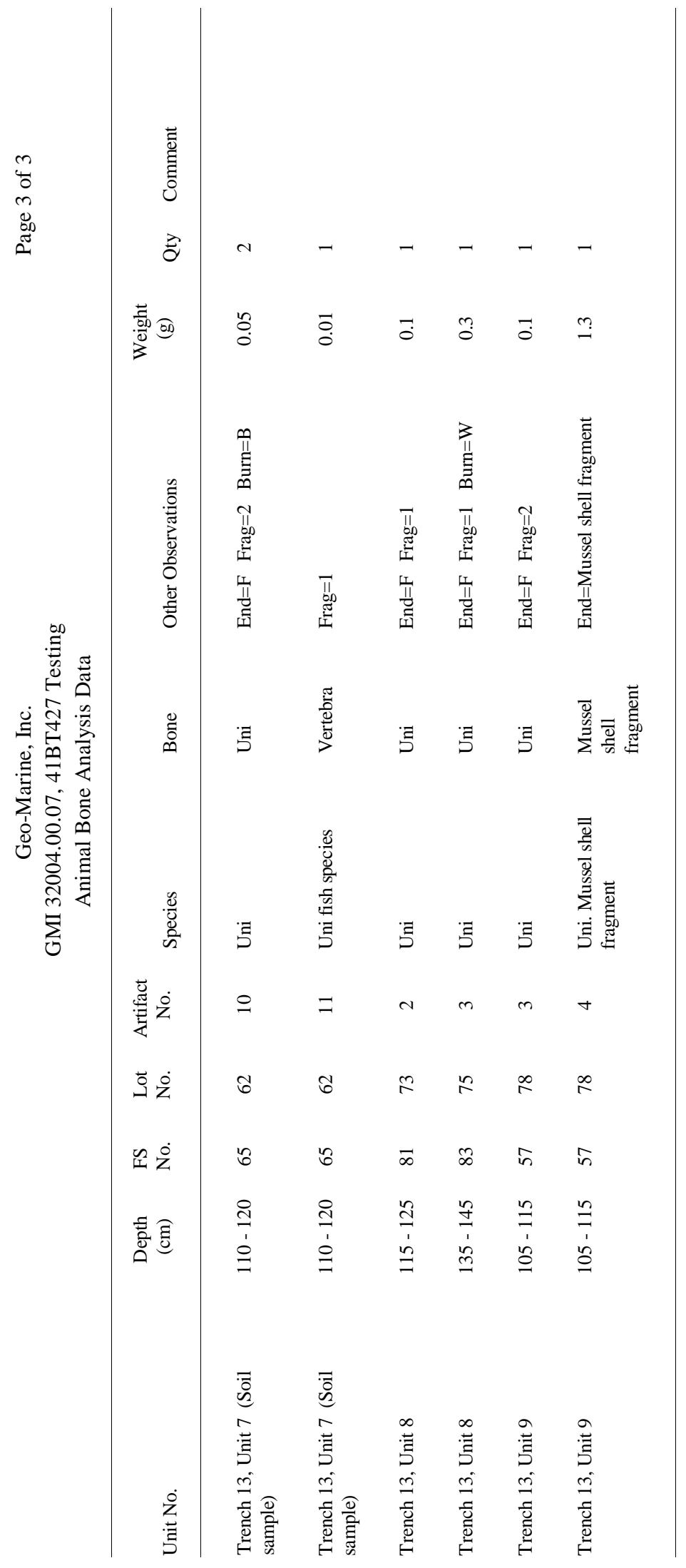





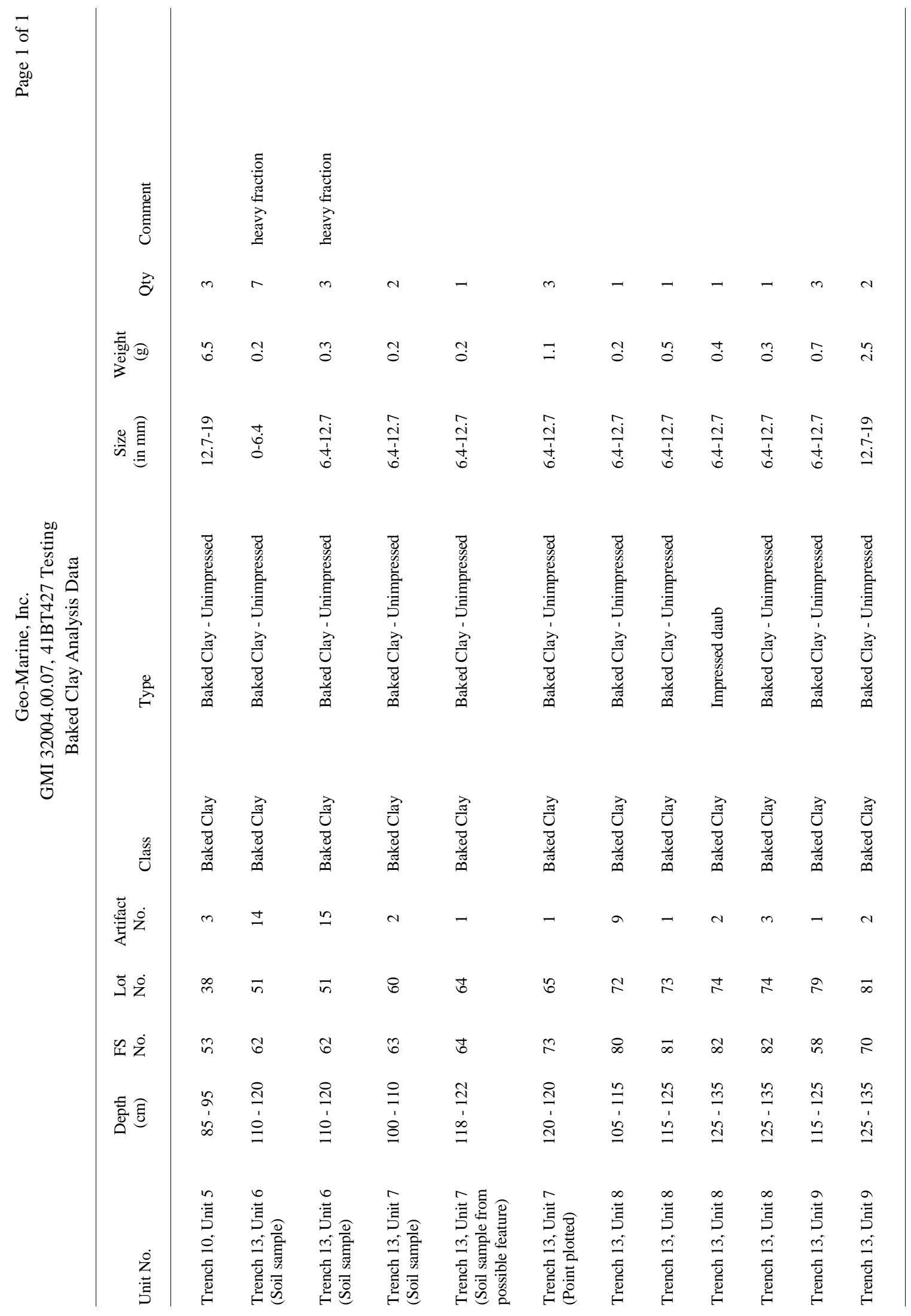





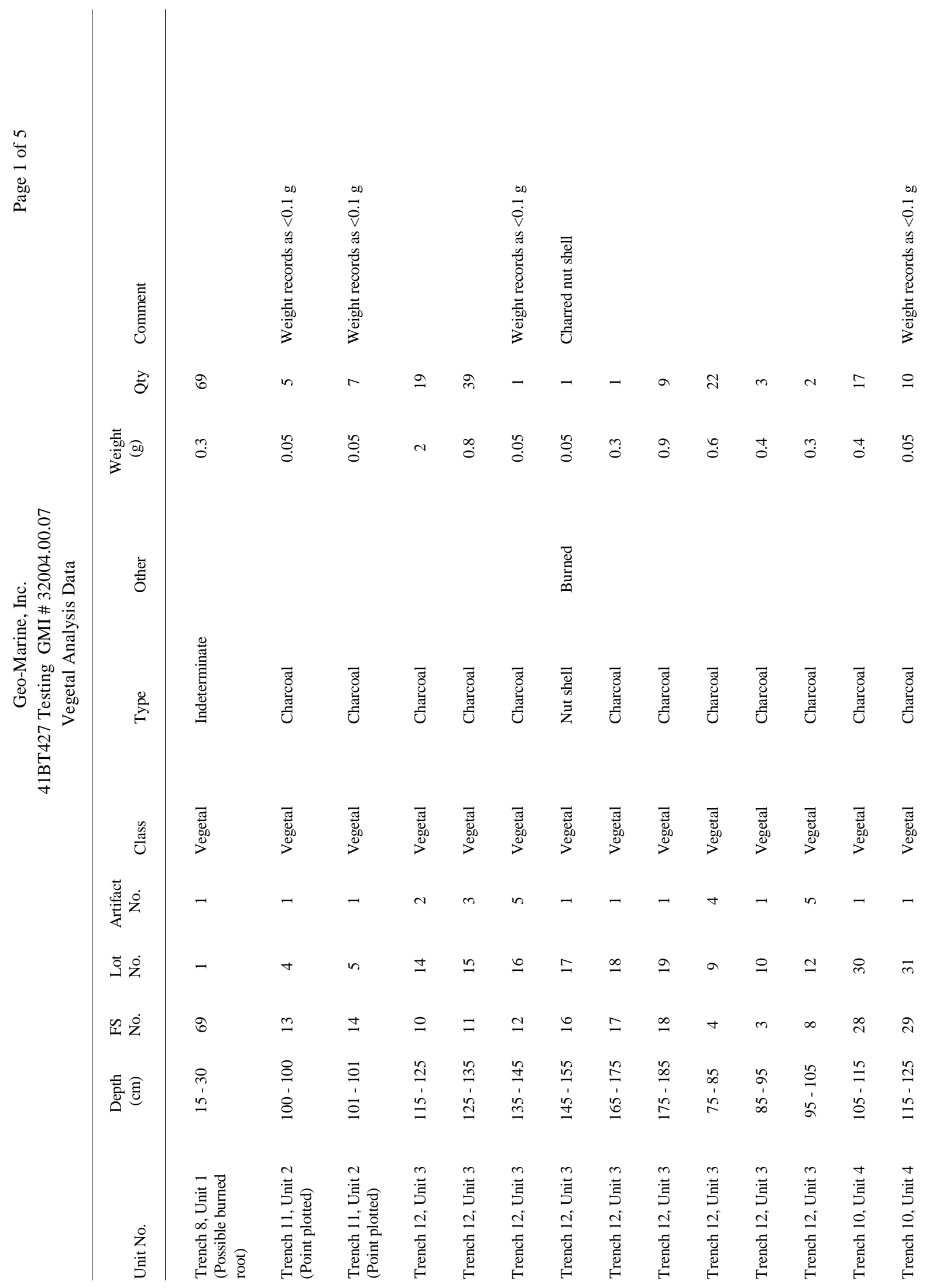




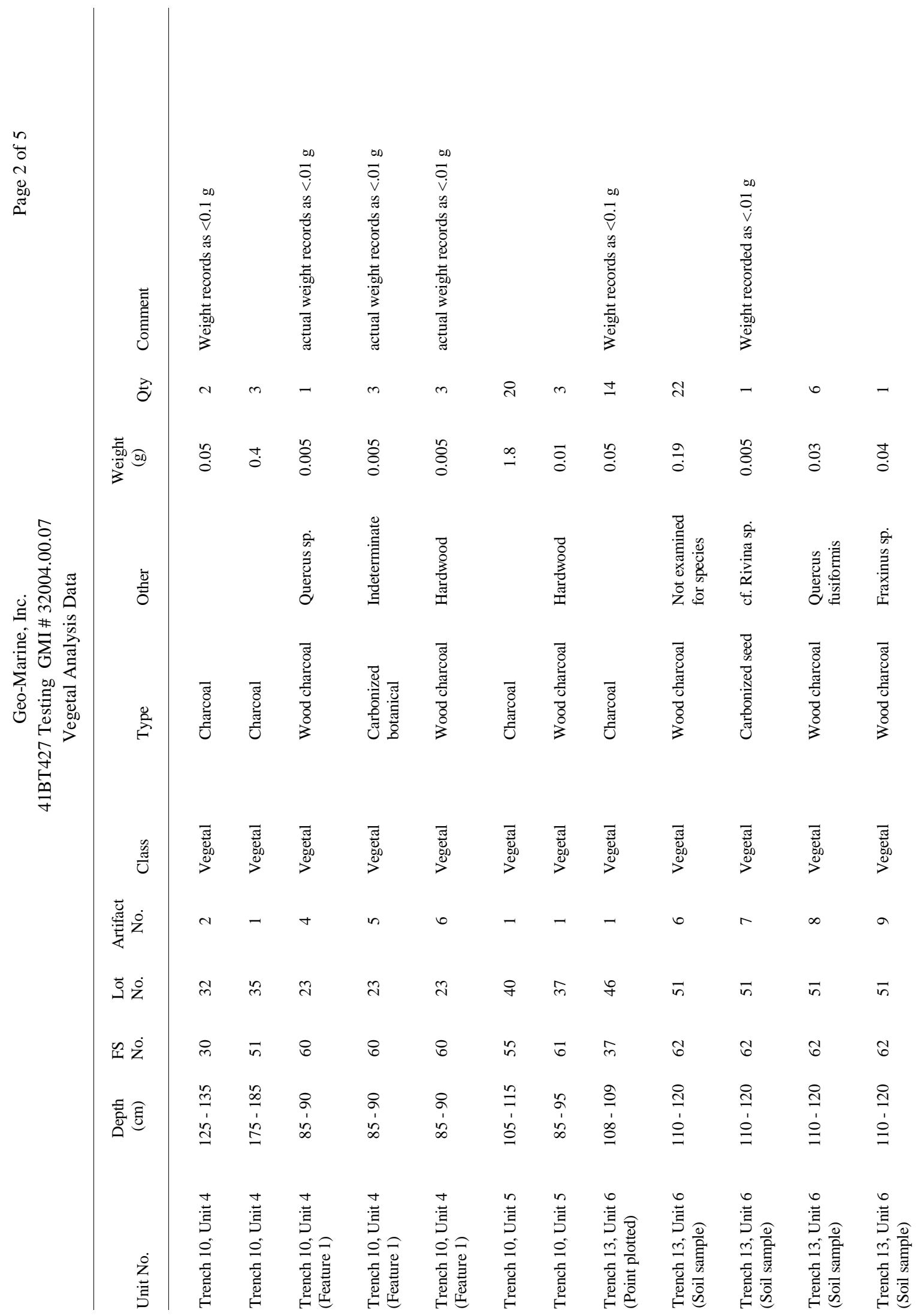




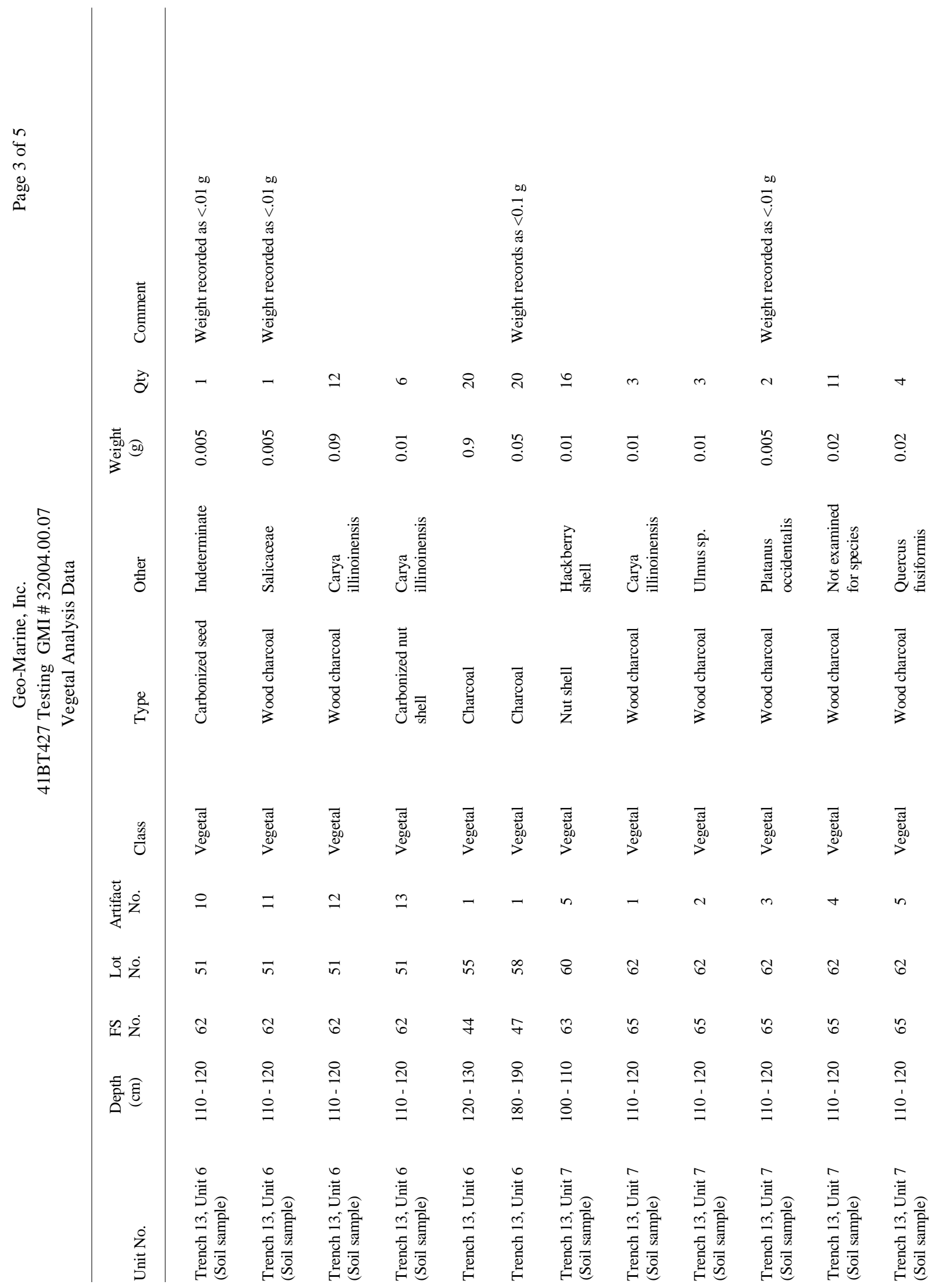




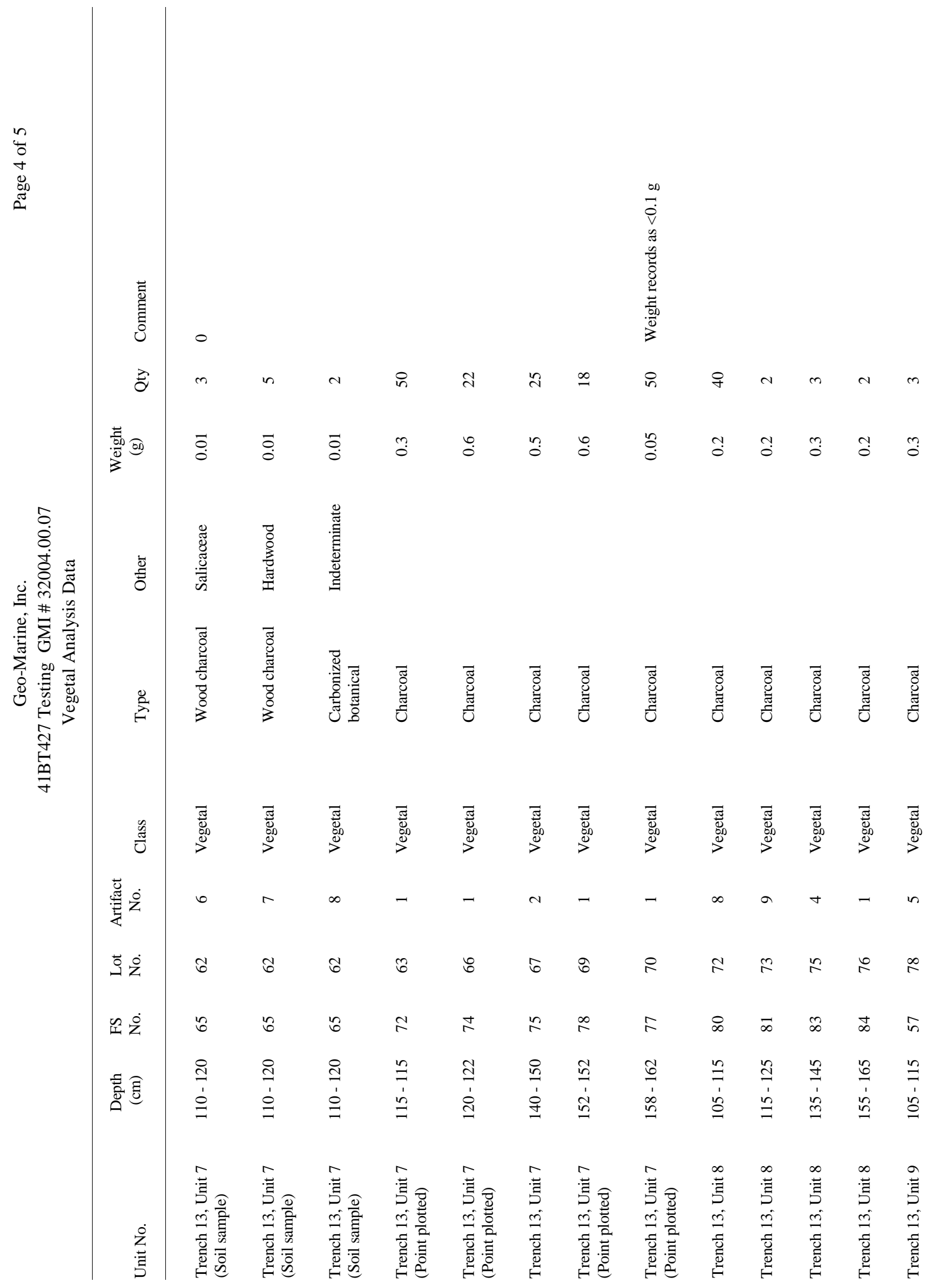




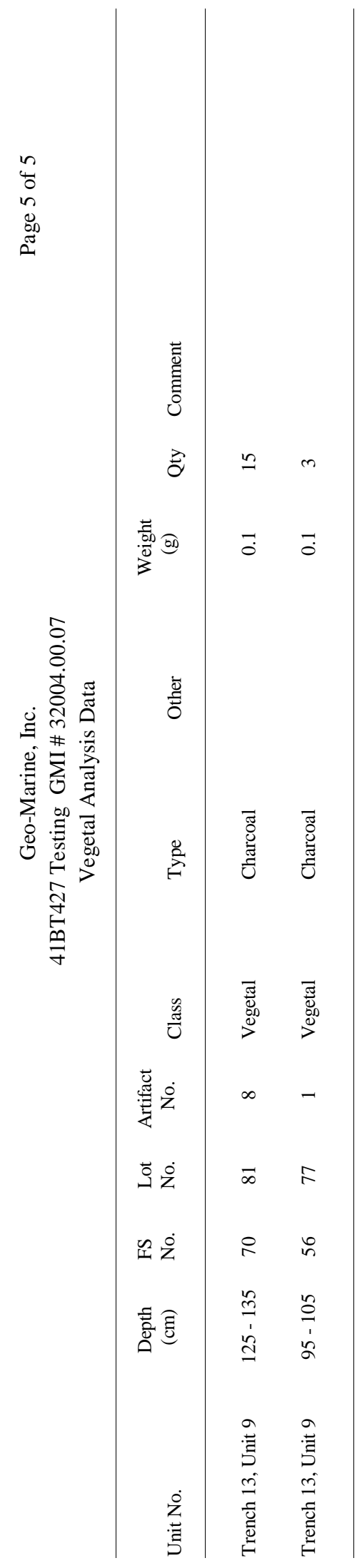



APPENDIX B

PLANT REMAINS FROM SITE 41BT427 



\section{Plant Remains from \\ SITE 41BT427 \\ Burnet County, Texas}

March 5, 2010

Prepared for:

Melissa M. Green, RPA

Principal Investigator

Geo-Marine, Inc.

2201 K Avenue, Suite A2

Plano, Texas 75074

Prepared by:

Leslie L. Bush, Ph.D., R.P.A.

Macrobotanical Analysis

12308 Twin Creeks Rd., B-106

Manchaca, Texas 78652 

Four flotation samples from Site 41BT427 were submitted for identification and analysis of botanical macroremains. The flotation samples represent three features and non-feature fill for a total of twenty cubic deciliters of soil matrix. The site is situated in northwestern Burnet County on a low terrace of North Rocky Creek approximately 500 meters above its confluence with South Rocky Creek.

\section{Site setting}

Site 41BT427 lies in the Lampassas cut plain, a vegetation area grouped variously with the Edwards Plateau (Riskind and Diamond 1988) or the Cross Timbers (Diggs et al. 1999; Gould 1962). A mosaic of grasslands and woodlands characterizes the vegetation. Grasslands are mixed prairie, with tall, medium and short grasses present. Upland trees and shrubs typically grow in mottes of oaks, juniper, and agarito. Yaupon and deciduous holly, elbowbush, persimmon, and sumac are common small trees and shrubs. Moister areas along streams and mesic slopes support trees such as sycamore, pecan, hackberry and elm (Beaty 1978; Riskind and Diamond 1988).

Site 41BT427 is at the southeastern edge of the Paluxy formation (Mehalchick et al. 2004:Figure 1.1), a geological formation associated with archaeological indications of geophyte processing. Soils at 41BT427, however, are generally alluvial in origin rather than outcroppings of Paluxy sands (THC site form, 7/10/2007). Excavators describe site soils as silty or sandy clay loam. According to survey maps, soil associations in the site area are Oakalla silty clay loams (Soil Survey Staff 2010).

\section{Methods}

Flotation samples were processed at Geo-Marine Inc's Plano offices in a Siraf tank flotation system with bottom mesh openings of $0.5 \mathrm{~mm}$ (Pearsall 2000:Figure 2.21). Flotation and carbon samples were sent to Macrobotanical Analysis in February 2010.

Flotation samples were sorted according to standard procedures (Pearsall 2000). Each sample was weighed on an Ohaus Scout II 200 x $0.01 \mathrm{~g}$ electronic balance before being sizesorted through a stack of graduated geologic mesh. Materials that did not pass through the No. 10 mesh ( $2 \mathrm{~mm}$ square openings) were completely sorted. At 41BT427, only three categories were present larger than $2 \mathrm{~mm}$ : carbonized macrobotanical remains, identifiable bones, and contamination. The "contamination" category includes uncarbonized botanical remains such as rootlets and hackberry seeds, gastropod and bivalve shells, soil clumps, and rocks. All carbonized botanical remains and identifiable bones were counted, weighed, recorded, and labeled. Contamination was weighted, recorded, and labeled only. Materials that fell through the $2 \mathrm{~mm}$ mesh ("residue") were examined under a stereoscopic microscope at 7-45 X magnification for carbonized botanical remains. Identifiable material was removed from residue, counted, weighed, recorded, and labeled. Although wood charcoal smaller than $2 \mathrm{~mm}$ is not usually removed from residue, so little wood charcoal was present in three of the samples that wood charcoal greater than $0.7 \mathrm{~mm}$ was removed from FS\#60 and FS\#61 and wood charcoal greater than $1.4 \mathrm{~mm}$ was

removed from FS\#65. Uncarbonized macrobotanical remains were recorded on a presence/absence basis on laboratory forms. 
For each flotation sample, wood charcoal fragments were selected at random for identification. Fragments were snapped to reveal a clean transverse section and examined under a stereoscopic microscope at 28-180 X magnification. When necessary, tangential or radial sections were examined for ray seriation, presence of spiral thickenings, types and sizes of intervessel pitting, and other minute characteristics that can only be seen at the higher magnifications of this range.

Botanical materials were identified to the lowest possible taxonomic level by comparison to materials in the Macrobotanical Analysis comparative collection and through the use of standard reference works (e.g., Core et al. 1979; Davis 1993; Hoadley 1990; Martin and Barkley 1961; Musil 1963; Panshin and de Zeeuw 1980). Plant nomenclature follows that of the PLANTS Database (USDA, NRCS 2010).

\section{Results}

Macrobotanical remains recovered by flotation are given in Tables B-1 and B-2 by count and weight, respectively. Table B-3 lists uncarbonized seeds on a presence/absence basis.

Table B-1

Carbonized Plant Remains from 41BT427, Counts

\begin{tabular}{lrrrr}
\hline FS\# & $\mathbf{6 0}$ & $\mathbf{6 1}$ & $\mathbf{6 2}$ & $\mathbf{6 5}$ \\
Feature type & hearth & non-feature & hearth & hearth \\
Test Unit & 4 & 5 & 6 & 7 \\
Depth (cmbg) & $85-90$ & $85-95$ & $110-120$ & $110-120$ \\
Volume (cu. deciliters) & 5 & 5 & 5 & 5 \\
Wood charcoal & & & 6 & 4 \\
Plateau live oak (Quercus fusiformis) & & & 12 & 3 \\
Pecan (Carya illinoinensis) & 1 & & & 3 \\
Oak (Quercus spp.) & & & 1 & 3 \\
Elm (Ulmus sp.) & & & & 2 \\
Ash (Fraxinus sp.) & & & 22 & 5 \\
Willow/cottonwood family (Salicaceae) & 3 & & & \\
Sycamore (Platanus occidentalis) & & & 6 & \\
Indeterminable hardwood & & & 1 & \\
Not examined for species & & & 1 & \\
Nutshell & & & & \\
Pecan (Carya illinoinensis) & & & & \\
Seeds & & & & \\
Coralito (Rivina humilis)? & & & & \\
Indeterminable & & & & \\
Indeterminable, probably botanical & & & & \\
\hline
\end{tabular}


Table B-2

Carbonized Plant Remains from 41BT427, Weight in Grams

\begin{tabular}{lrrrr}
\hline FS\# & $\mathbf{6 0}$ & $\mathbf{6 1}$ & $\mathbf{6 2}$ & $\mathbf{6 5}$ \\
Feature type & hearth & non-feature & hearth & hearth \\
Test Unit & 4 & 5 & 6 & 7 \\
Depth (cmbg) & $85-90$ & $85-95$ & $110-120$ & $110-120$ \\
Volume (cu. deciliters) & 5 & 5 & 5 & 5 \\
Wood charcoal & & & 0.03 & 0.02 \\
Plateau live oak (Quercus fusiformis) & & & 0.09 & 0.01 \\
Pecan (Carya illinoinensis) & 0.01 & & & 0.01 \\
Oak (Quercus spp.) & & & 0.04 & \\
Elm (Ulmus sp.) & & & 0.01 & 0.01 \\
Ash (Fraxinus sp.) & & & 0.19 & 0.01 \\
Willow/cottonwood family & & & & 0.02 \\
(Salicaceae) & 0.01 & & 0.01 & \\
Sycamore (Platanus occidentalis) & & & 0.01 & \\
Indeterminable hardwood & & & 0.01 & \\
Not examined for species & & & & 0.01 \\
Nutshell & & & & \\
Pecan (Carya illinoinensis) & & & & \\
Seeds & & & & \\
Coralito (Rivina humilis)? & & & & \\
Indeterminable & & & & \\
Indeterminable, probably botanical & & & & \\
\hline
\end{tabular}

Table B-3

Uncarbonized Seeds from 41BT427, Presence/Absence

\begin{tabular}{lrrrr}
\hline FS\# & $\mathbf{6 0}$ & $\mathbf{6 1}$ & $\mathbf{6 2}$ & $\mathbf{6 5}$ \\
Depth (cmbg) & $85-90$ & $85-95$ & $110-120$ & $110-120$ \\
Volume (cu. deciliters) & 5 & 5 & 5 & 5 \\
Grass family (Poaceae) & $\mathrm{X}$ & & $\mathrm{X}$ & $\mathrm{X}$ \\
Mesquite (Prosopis sp.) & & & & $\mathrm{X}$ \\
Hackberry (Celtis sp.) & & & & $\mathrm{X}$ \\
Sandmat (Chamaesyce sp.) & & $\mathrm{X}$ & \\
Unknown (samara, 7 mm) & & & \\
\hline
\end{tabular}




\section{Uncarbonized plant remains}

Most uncarbonized plant remains at 41BT427 appear in the form of rootlets that are clearly modern and not reported here. In addition, five types of uncarbonized seeds were recovered in flotation (see Table B-3). Uncarbonized seeds are a common occurrence on most archaeological sites, but they usually represent seeds of modern plants that have made their way into the soil either through their own dispersal mechanisms or by faunalturbation, floralturbation, or argilliturbation (Bryant 1985:51-52; Keepax 1977; Miksicek 1987:231-232). In all except the driest areas of North America, uncarbonized plant material on open-air sites can be assumed to be of modern origin unless compelling evidence suggests otherwise (Lopinot and Brussell 1982; Miksicek 1987:231). Site 41BT427 has offered no such evidence, and the seeds are interpreted as modern seed rain. One taxon, however, merits further discussion.

The hackberry problem. Unlike the other uncarbonized seeds from site 41BT427, hackberry seeds are known to persist for many centuries in the soil. Hackberry's high resistance to decay presents particular interpretive difficulties on archaeological sites. What archaeologists typically recover is the hackberry endocarp, the thick white seedcoat from under the under thin fleshy layer of the fruit. The endocarp has a high mineral content: It contains 40-70 percent aragonite, a crystalline form of calcium carbonate (Wang et al. 1997; Yanovsky et al. 1932). The carbonate helps hackberry endocarps preserve unusually well in the soil, and it makes hackberry endocarps excellent candidates for dating of the geological sediments in which they originated. Yang Wang and colleagues argue that dating of sediments by hackberry inclusions is preferable to other methods. Since the carbonates form over a single growing season, their initial ${ }^{14} \mathrm{C}$ content is the same as that in the atmosphere, and they can be tested for reliability before dating (Wang et al. 1997:342). Hackberry endocarps are surprisingly common in geological and archaeological strata (Wang et al. 1997:337) - but they are not necessarily archaeological in origin. The difficulty for archaeobotanists is determining whether the hackberry endocarps represent the traces of human hackberry use or merely the presence of hackberries at the site location (or the location at which the site sediments originated).

The single, whole hackberry seed from FS\#65 at 41BT427 is white in color and therefore has not been exposed to the cultural agent of fire as the demonstrably ancient plants have. Most likely, it represents recent seed rain. Hackberry fruits are a candidate for ancient plant exploitation at 41BT427, however, because they were likely present near the confluence of North Rocky Creek and South Rocky Creek in prehistoric times and were widely used by historic people (Moerman 1998). The particular hackberry observed in the samples, however, probably does not represent the archaeological traces of this activity. Further discussion of the plant remains from 41BT427 concerns carbonized plants only.

\section{Carbonized plant remains}

Wood charcoal. A total of 80 fragments weighing $1.48 \mathrm{~g}$ were recovered and 47 fragments were identified (Figure B-1). Eleven wood fragments (23\%) were too small or in too poor condition to be identified more specifically than as a hardwood. Interestingly, oaks make up only $23 \%$ of the assemblage. Even if all indeterminable fragments were oak, it would still make up less than half the assemblage. Oak typically comprises 60-80 percent of the wood charcoal in burned rock features in central Texas (Mehalchick et al. 2004; Bush 2009; Bush 2010). Most likely, inhabitants at 41BT427 were collecting wood for fuel from the riparian environment in the immediate site area, where pecan, elm, ash, sycamore, and willow or cottonwood are more common than oaks, which dominate the uplands. Although pecan burns nearly as hot as oak and 


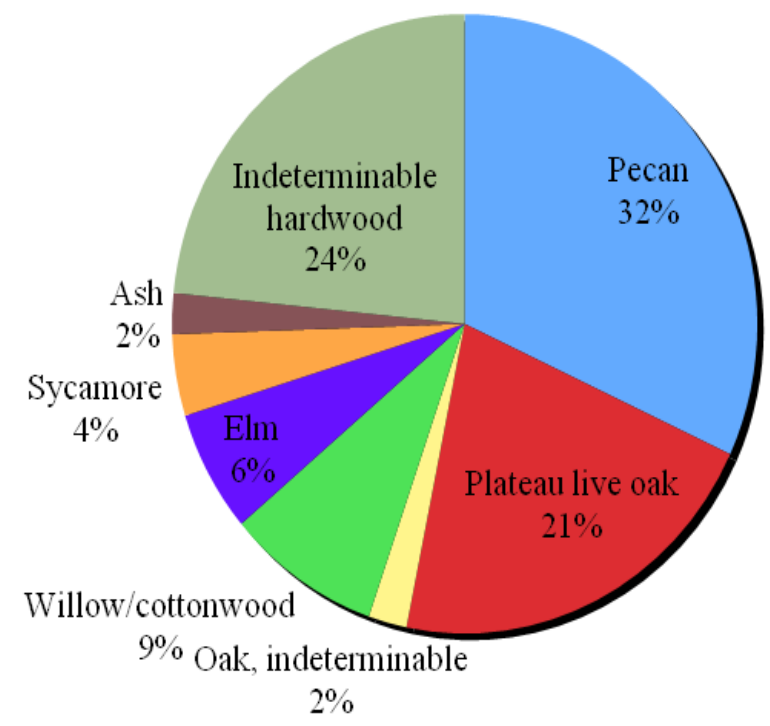

Figure B-1. Wood charcoal from site 41BT427 (n=47).

makes good coals, the other woods recovered are of considerably lower quality as firewood. Juniper is absent from the archaeological assemblage, both because it is a relatively poor fuelwood and because it would have been restricted to ravines and limestone outcrops in preagricultural times (Fonteyn et al. 1988:88).

Nutshell. Six fragments of pecan nutshell were recovered from FS\#62. Pecan nutshell is unlikely to have been carbonized incidental to the burning of pecan wood, since pecan nuts do not cling to the tree branches as the hulls do. Rather, it represents a probable ancient food resource for inhabitants of the site. Grant Hall points out that the fat in pecan nuts may have been critical to hunter-gatherers who relied on lean meat for a portion of the year (Hall 2000:109-110). Nutritional data for pecans are given in Table B-4.

Seeds. Two seeds were recovered from Feature 6, one of the three hearths. One seed is approximately one-third complete and cannot be identified. The other seed is saucer shaped, 1.5 $\mathrm{mm}$ in diameter, sparsely papillate in texture, with a triangular hilum nearly identical to that of pokeweed (Phytolacca americana). An identification of coralito (Rivina humilis) is suggested. Coralito, also called pigeon-berry or rougeplant, is a more delicate relative of pokeweed that grows in woodlands near streams. It has smaller seeds than pokeweed. The seed texture is described as hairy (Diggs et al. 1999:882), whereas pokeweed seeds are smooth. Both pokeweed and coralito are considered toxic, but their berries make excellent red dyes (Correll and Johnston 1970; Tull 1987). 
Table B-4

Nutrient Values for Pecan Nuts per $100 \mathrm{~g}$ Edible Portion

(USDA, ARS 2009)

\begin{tabular}{lr}
\hline Water $(\mathrm{g})$ & 3.52 \\
Energy $(\mathrm{kcal})$ & 691 \\
Energy $(\mathrm{kj})$ & 2889 \\
Protein $(\mathrm{g})$ & 9.17 \\
Total lipid $(\mathrm{g})$ & 71.97 \\
Ash $(\mathrm{g})$ & 1.49 \\
Carbohydrate, by difference $(\mathrm{g})$ & 13.86 \\
\hline
\end{tabular}

\section{Summary}

Macroflora from Site 41BT427 show selection of wood in the immediate vicinity of the site for fuel despite the relatively low fuel value of some of those taxa. Feature 6 yielded pecan nutshells, indicating exploitation of nut resources that may have provided valuable dietary fat. The three samples from feature (hearth) contexts contained a higher density of carbonized botanical material than did the non-feature sample (FS\#61). 


\section{REFERENCES CITED}

\section{Beaty, Harold E.}

1978 A Checklist of Flora and Fauna, Central and West Bell County, Texas. Ms. on file, University of Texas at Austin, Life Sciences Library.

Bryant, John A.

1985 Seed Physiology. The Institute of Biology's Studies in Biology No. 165. Edward Arnold, Ltd., London.

Bush, Leslie L.

2009 Plant Remains from Three Burned Rock Middens at Fort Hood, Coryell County, Texas. Report submitted to Prewitt and Associates, Inc., Austin, Texas. October 20, 2009.

2010 Preliminary Report on a Flotation Sample from Eagle Bluff (41ME147): Medina County, Texas. Report submitted to Texas Archeological Society, San Antonio, Texas. February 23, 2010.

Core, H. A., W. A. Cote and A. C. Day

1979 Wood Structure and Identification. 2nd ed. Syracuse University Press, Syracuse, NY.

Correll, Donovan Stewart and Marshall Conring Johnston

1970 Manual of the Vascular Plants of Texas. Texas Research Foundation, Renner.

Davis, Linda W.

1993 Weed Seeds of the Great Plains: A Handbook for Identification. University Press of Kansas, Lawrence.

Diggs Jr., George M., Barney L. Lipscomb and Robert J. O'Kennon

1999 Shinners and Mahler's Illustrated Flora of North Central Texas. Second Printing, 2000, with minor corrections. Illustrated Texas Floras Project. Botanical Research Institute of Texas, Fort Worth. 
Fonteyn, Paul J., M. Wade Stone, Malinda A. Yancy, John T. Baccus and Nalini M. Nadkarni 1988 Determination of Community Structure by Fire. In Edwards Plateau Vegetation: Plant Ecological Studies in Central Texas, edited by Bonnie B. Amos and Frederick R. Gehlbach. Baylor University Press, Waco, Texas.

Gould, Frank W.

1962 Texas Plants -- A Checklist and Ecological Summary. The Agricultural and Mechanical College of Texas, Texas Agricultural Experiment Station, College Station, Texas.

Hall, Grant D.

2000 Pecan Food Potential in Prehistoric North America. Economic Botany 54(1):103-112.

Hoadley, R. Bruce

1990 Identifying Wood: Accurate Results with Simple Tools. The Taunton Press, Newtown, Connecticut.

Keepax, Carole

1977 Contamination of archaeological deposits by seeds of modern origin with particular reference to the use of flotation machines. Journal of Archaeological Science 4:221229.

Lopinot, Neal H. and David Eric Brussell

1982 Assessing Uncarbonized Seeds from Open-air Sites in Mesic Environments: An Example from Southern Illinois. Journal of Archaeological Science 9:95-108.

Martin, Alexander C. and William D. Barkley

1961 Seed Identification Manual. University of California Press, Berkeley.

Mehalchick, Gemma, Douglas K. Boyd, Karl W. Kibler and Christopher W. Ringstaff

2004 Shifting Sands and Geophytes: Geoarcheological Investigations at Paluxy Sites on Fort Hood, Texas. United States Army Fort Hood Archeological Resource Management Series, Research Report No. 48.

Miksicek, Charles H.

1987 Formation Processes of the Archaeobotanical Record. In Advances in Archaeological Method and Theory, Vol. 10, edited by Michael B. Schiffer, pp. 211-247. Academic Press, Inc.

Moerman, Daniel E.

1998 Native American Ethnobotany. Timber Press, Portland, Oregon.

Musil, Albina F.

1963 Identification of Crop and Weed Seeds Agriculture Handbook No. 219. U.S. Department of Agriculture, Washington, D.C.

Niering, William A. and Nancy C. Olmstead

1979 The Audubon Society Field Guide to North American Wildflowers: Eastern Region. Alfred A. Knopf, New York. 
Panshin, A. J. and Carol de Zeeuw

1980 Textbook of Wood Technology: Structure, Identification, Properties, and Uses of the Commercial Woods of the United States and Canada. Fourth ed. McGraw-Hill Book Company, New York.

Pearsall, Deborah M.

2000 Paleoethnobotany: A Handbook of Procedures. 2nd ed. Academic Press, San Diego.

Riskind, David H. and David D. Diamond

1988 An Introduction to Environments and Vegetation. In Edwards Plateau Vegetation: Plant Ecological Studies in Central Texas, edited by Bonnie B. Amos and Frederick R. Gehlbach, pp. 1-15. Baylor University Press, Waco, Texas.

Soil Survey Staff

2010 Natural Resources Conservation Service, United States Department of Agriculture. Web Soil Survey. http://websoilsurvey.nrcs.usda.gov. Accessed 2/18/10.

Tull, Delena

1999 Edible and Useful Plants of Texas and the Southwest. University of Texas Press, Austin.

USDA, ARS (United States Department of Agriculture, Agricultural Research Service)

2009 USDA National Nutrient Database for Standard Reference. Release 22. Accessed 2/23/10.

USDA, NRCS (United States Department of Agriculture, Natural Resources Conservation Service)

2010 The PLANTS Database. United States Department of Agriculture, Natural Resources Conservation Service. http://plants.usda.gov. Accessed 2/3/10

Wang, Yang, A. Hope Jahren and Ronald Amundson

1997 Potential for 14C dating of Biogenic Carbonate in Hackberry (Celtis) Endocarps. Quaternary Research 47:337-343.

Yanovsky, E., E. K. Nelson and R. M. Kingsbury

1932 Berries Rich in Calcium. Science 75(1952):565-566. 

APPENDIX C

RESULTS OF RADIOCARBON DATING 



\begin{tabular}{|c|c|c|}
\hline Sample Data & $\begin{array}{c}\text { Measured } \\
\text { Radiocarbon Age }\end{array}$ & $\begin{array}{c}13 \mathrm{C} / 12 \mathrm{C} \\
\text { Ratio }\end{array}$ \\
\hline $\begin{array}{l}\text { Beta - } 236942 \\
\text { SAMPLE : BT427-TU4-L2 } \\
\text { ANALYSIS : AMS-Standard delive } \\
\text { MATERIAL/PRETREATMENT : } \\
\text { 2 SIGMA CALIBRATION : }\end{array}$ & $\begin{array}{l}\qquad 1320+/-40 \mathrm{BP} \\
\text { ery } \\
\text { (charred material): acid/alkali/acid } \\
\text { Cal AD } 650 \text { to } 780(\text { Cal BP } 1300 \text { to } 1170)\end{array}$ & $-25.9 \mathrm{o} / 00$ \\
\hline $\begin{array}{l}\text { Beta - } 236943 \\
\text { SAMPLE : BT427-TU6-L44 } \\
\text { ANALYSIS : AMS-Standard delive } \\
\text { MATERIAL/PRETREATMENT : } \\
2 \text { SIGMA CALIBRATION : }\end{array}$ & $\begin{array}{l}\qquad 1270+/-40 \mathrm{BP} \\
\text { ery } \\
\text { (charred material): acid/alkali/acid } \\
\text { Cal AD } 660 \text { to } 780(\text { Cal BP } 1290 \text { to } 1160)\end{array}$ & $-24,0 \mathrm{o} / 00$ \\
\hline
\end{tabular}




\section{CALIBRATION OF RADIOCARBON AGE TO CALENDAR YEARS}

(Variables: C13/C12=-25.9:1ab. mult $=1$ )

\section{Laboratory number: $\quad$ Beta-236942}

\section{Conventional radiocarbon age: $1310 \pm 40 \mathrm{BP}$}

2 Sigma calibrated result: Cal AD 650 to 780 (Cal BP 1300 to 1170)

(95\% probability)

In tercept data

Intercept of radiocarbon age with calibration curve: Cal AD 680 (Cal BP 1270)

1 Sigma calibrated results: Cal AD 660 to 710 (Cal BP 1290 to 1240) and

(68\% probability) Cal AD 750 to 760 (Cal BP 1200 to 1190 )

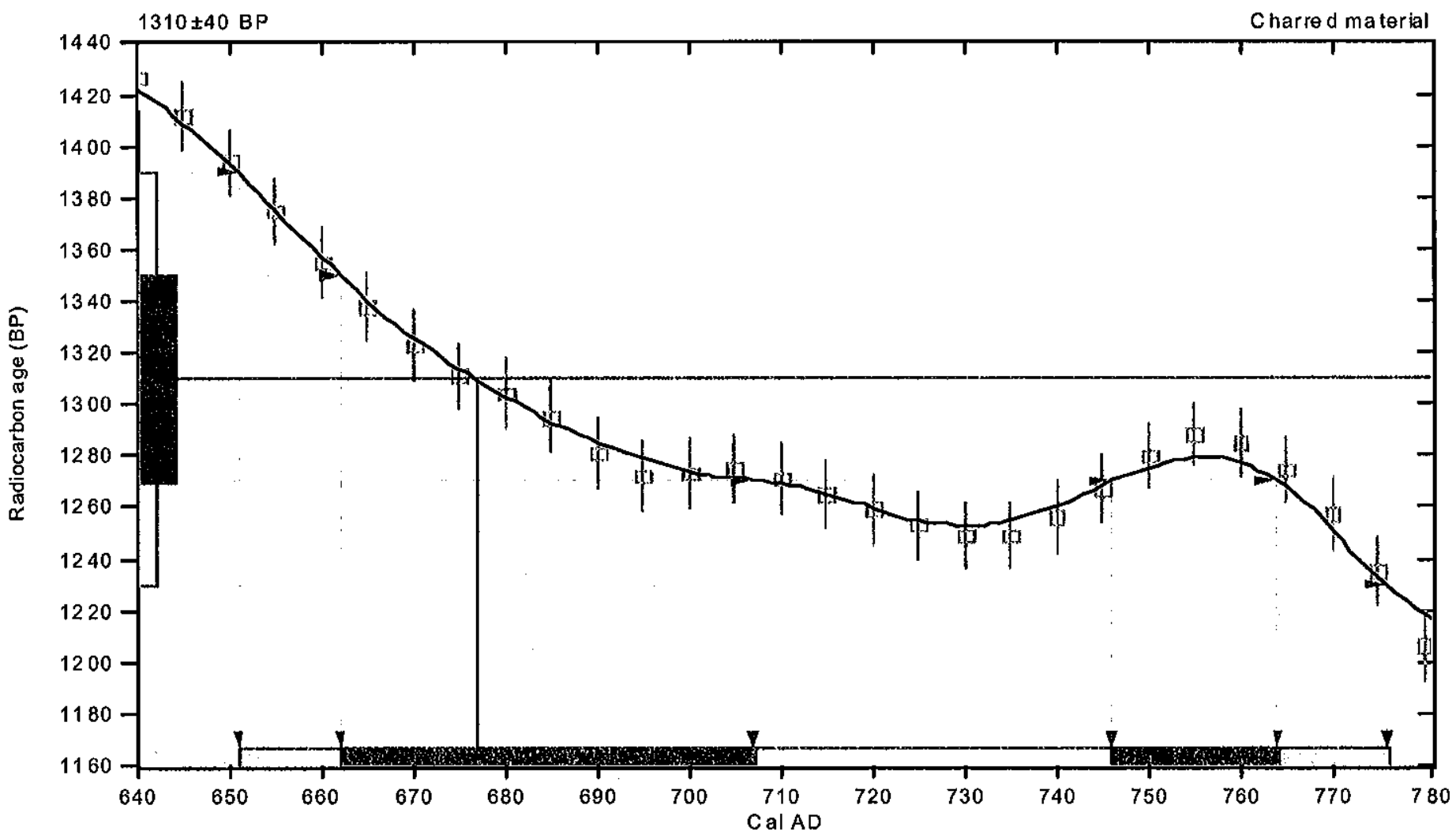

References:

Data base used INTCA LO 4

Calib ration Database

INTCALO4 Ra diocarbon Age Callbration IntCal0 4: Calibration Is stue of Radio carbon (Volume 46, nr 3, 2004).

Mathematics

A Simplifed Approach to Calibrating C14 Dates Talma, A.S., Vogel, J. C., $1993, R$ adiocarbon 35(2), p317-322 


\section{CALIBRATION OF RADIOCARBON AGE TO CALENDAR YEARS}

(Variables: $\mathrm{C} 13 / \mathrm{C} 12=-24: 1 \mathrm{ab}$, mult=1)

Laboratory number: Beta-236943

Conventional radiocarbon age: $1290 \pm 40 \mathrm{BP}$

2 Sigma calibrated result: Cal AD 660 to 780 (Cal BP 1290 to 1160) (95\% probability)

In tercept data

Intercept of radiocarbon age with calibration curve: Cal AD 690 (Cal BP 1260)

1 Sigma calibrated result: Cal AD 670 to 770 (Cal BP 1280 to 1180 ) (68\% probability)

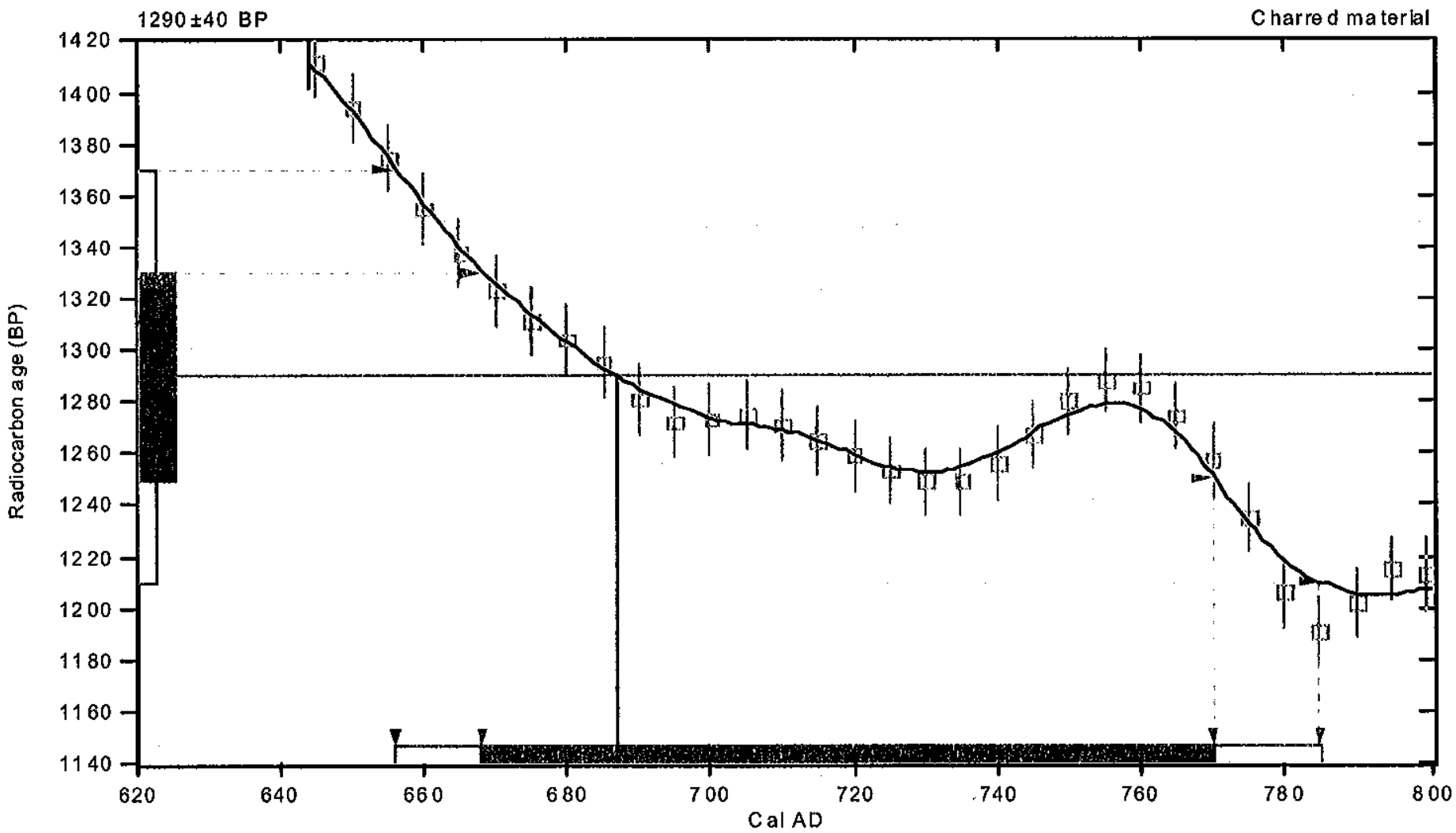

References:

Database used INTCA LO 4

Ca lib ration Database

INTCALO4 Radiocarbon Age Calibration

IntCal0 4: Calibration Is sue of Radio carbon (Volume 46, nr 3, 2004).

Math em atics

A Simplified Approach to Callbrating C14 Dates

Talma, A. S., Vogel, J. C., 1993, R adiocarbon 35(2), p317-322

\section{Beta Analytic Radiocarbon Dating Laboratory}

4985 S.W.74th Court, Miami, Florida 33155 - Tel: (305)667-5167-Fax: (305)663-0964-E-Mail: beta@radiocarbon.com 
